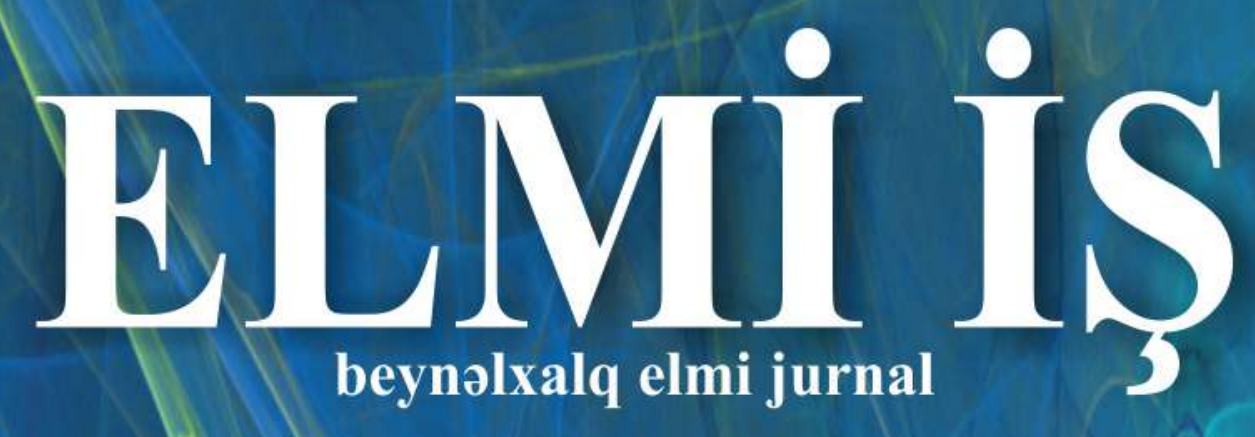

\title{
SCIENTIFIC WORK
}

International scientific journal

\section{RESPUBLİKA ELMI QAYNAQLAR KONFRANSININ}

\author{
M A T E R İ A L L A R I \\ (30 iyun 2021)
}

\section{MA T E R I A L S}

OF THE

IV REPUBLICAN CONFERENCE OF SCIENTIFIC SOURCES

(30 June, 2021) 


\title{
ELMİ îş
}

beynəlxalq elmi jurnal

1.518 Yüksək İmpakt Faktorlu

\section{RESPUBLIKA ELMI QAYNAQLAR KONFRANSININ M A T E R İ A L L A R I}

(30 iyun 2021)

DOI: https://www.doi.org/10.36719/2663-4619/2021/02/04

\section{SCIENTIFIC WORK}

International scientific journal

With High Impact Factor 1.518

\author{
M A T E R I A L S \\ OF THE \\ IV REPUBLICAN CONFERENCE \\ OF SCIENTIFIC SOURCES
}

(June 30, 2021)

Bakı - Baku 
Jurnal Azərbaycan

Respublikası Әdliyyə Nazirliyi Mətbu nəşrlərin reyestrinə 25.04.2007-ci ildə daxil edilmişdir. Reyestr №2212

The journal is included in the Register of Press editions of the Ministry of Justice of the Republic of Azerbaijan on 25.04.2007.

Registration number: 2212

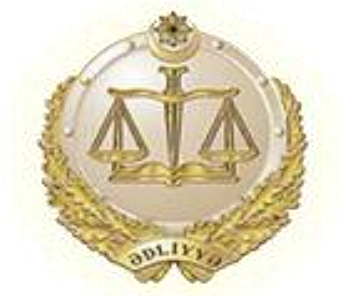

Azzopaycan Matbuat Șurası

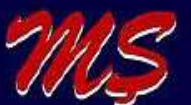

Azerbaijan Press Council
Beynəlxalq indekslər / International indices

ISSN: 2663-4619 e-ISSN: 2708-986X DOI: 10.36719
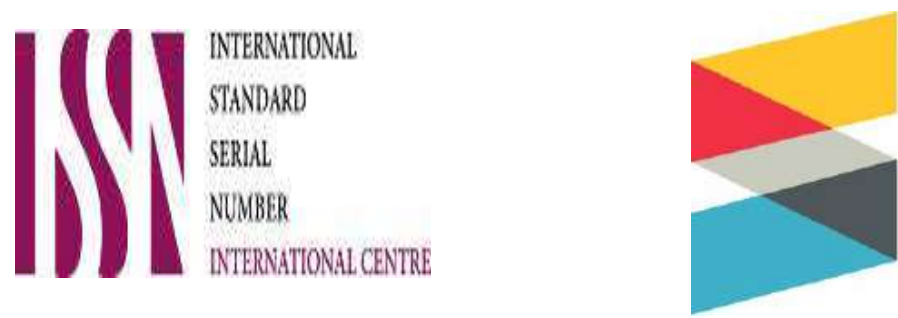

Crossref

Content

Registration

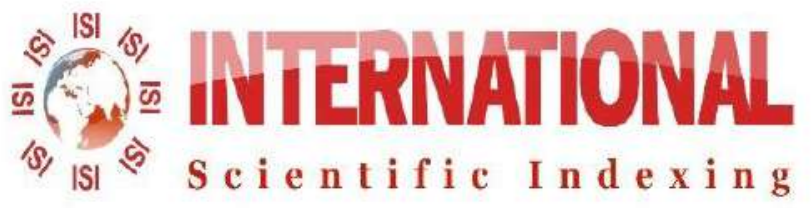

ڤs, $\mid$ s 5 sientific Indexing
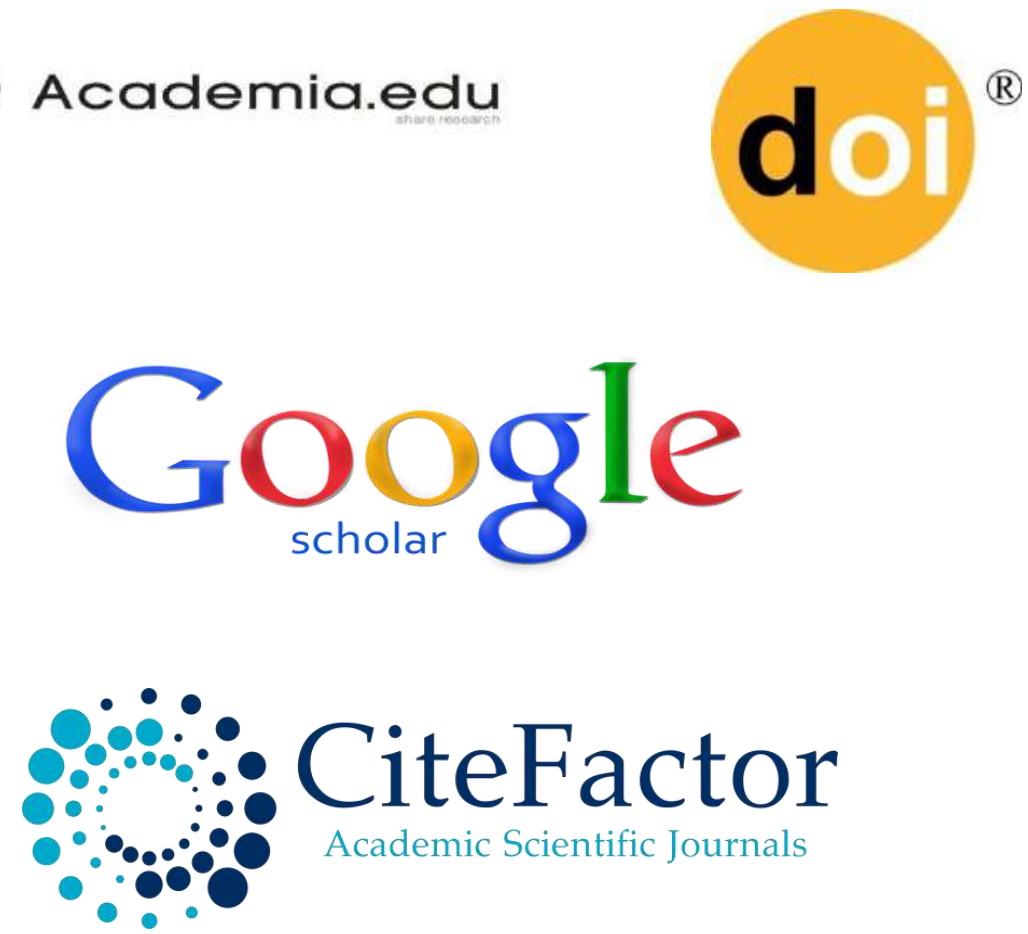

(C) Jurnalda çap olunan materiallardan istifadə edərkən istinad mütləqdir.

(C) It is necessary to use reference while using the journal materials.

(C) www.aem.az 


\section{TəŞKILAT KOMITəSi}

SODR:

Qəzənfər KAZIMOV, filologiya elmləri doktoru, professor, AMEA Dilçilik İnstitutu

SODR MÜAVINLORİ:

Mübariz HÜSEYINOV, "Elmi iş" beynəlxalq elmi jurnalın baş redaktoru

Oləmdar ŞAHVERDIYEV, tarix elmləri doktoru, dosent, Bakı Dövlət Universiteti

MOSUL KATIB:

Dürdanə HÜMBəTOVA, filologiya üzrə fəlsəfə doktoru, dosent

ÜZVLOR:

Vaqif ABBASOV, akademik, AMEA Neft-Kimva Prosesləri İnstitutu

Norgiz AXUNDOVA, akademik, AMEA Tarix İnstitutu

İbrahim COFOROV, AMEA-nın müxbir üzvü, Azərbaycan Dövlət Aqrar Universiteti

Ceyran MAHMUDOVA, sənətşünaslıq elmləri doktoru, professor, Azərbaycan Dövlət Mədəniyyət və İncəsənət Universiteti

İzzət RÜSTӘMOV, fəlsəfə elmləri doktoru, professor, Bakı Dövlət Universiteti

Məhərrəm QASIMLI, filologiya elmləri doktoru, professor, AMEA Odəbiyyat İnstitutu

Şirindil ALIŞANOV, filologiya elmləri doktoru, professor, AMEA Әdəbiyyat İnstitutu

Omir OLIYEV, hüquq elmləri doktoru, professor, Bakı Dövlət Universiteti

Anar ÍSGəNDəROV, tarix elmləri doktoru, professor, Bakı Dövlət Universiteti

İradə HÜSEYNOVA, tarix elmləri doktoru, professor, Bakı Dövlət Universiteti

Rüfət RÜSTOMOV, filologiya elmləri doktoru, professor, Bak1 Dövlət Universiteti

Firuzə ABBASOVA, hüquq elmləri doktoru, professor, Bak1 Dövlət Universiteti

Rafail HəSəNOV, sosiologiya elmləri doktoru, professor, Bak1 Dövlət Universiteti

Elşad MİRBəŞıR OĞLU, siyasi elmlər doktoru, professor, Azərbaycan Respublikası Prezidenti yanında Dövlət

İdarəcilik Akademivası

Şəhla SəMəDOVA, hüquq elmləri doktoru, professor, Bakı Dövlət Universiteti

Şikar QASIMOV, tarix elmləri doktoru, professor, Azərbaycan Texniki Universiteti

Müsevib İLYASOV, pedaqogika elmləri doktoru, professor, Azərbaycan Dövlət Pedaqoji Universiteti

Mönsüm ALIȘOV, pedaqoji elmlər doktoru, professor, "İdrak" liseyi

Abbas ABBASOV, filologiya üzrə fəlsəfə doktoru, professor, Bakı Dövlət Universiteti

Elçin HÜSEYN, biotibb elmləri doktoru, Azərbaycan Dövlət Neft və Sənaye Universiteti

Rəşid CABBAROV, psixologiya elmləri doktoru, dosent, Bakı Dövlət Universiteti

Nəriman SEYIDOLIYEV, filologiya elmləri doktoru, dosent, AMEA Dilçilik İnstitutu

Dürdanə МӘMМӘDOVA, hüquq üzrə fəlsəfə doktoru, dosent, Bakı Dövlət Universiteti

\section{CHAIRMAN:}

\section{THE ORGANIZING COMMITTEE}

Gazanfar KAZIMOV, doctor of philological sciences, professor, Institute of Linguistics of ANAS

DEPUTY CHAIRMAN:

Mubariz HUSEINOV, editor -in -chief of the international scientific journal "Scientific work"

Alamdar SHAHVERDIYEV, doctor of historical sciences, docent, Baku State University

EXECUTIVE SECRETARY:

Durdana HUMBATOVA, Phd in philology, docent

\section{MEMBERS}

Vagif ABBASOV. academician. Institute of Petrochemical Processes of ANAS

Nargiz AKHUNDOVA, academician, Institute of History of ANAS

Ibrahim .JAFAROV. corresponding member of ANAS. Azerbaiian State Agrarian Universitv

Jevran MAHMUDOVA. doctor of arts. professor. Azerbaiian State University of Culture and Arts

Izzet RUSTAMOV. doctor of Philosophv. Professor. Baku State Universitv

Maharram GASIMLI. doctor of philological sciences. professor. Institute of Literature of ANAS

Shirindil ALISHANOV. doctor of philological sciences. professor, Institute of Literature of ANAS

Amir ALIYEV. doctor of Law, professor. Baku State Universitv

Anar ISGANDAROV. doctor of historical sciences. professor. Baku State Universitv

Irada HUSEYNOVA, doctor of historical sciences, professor, Baku State University

Rufat RUSTAMOV, doctor of philology, professor, Baku State University

Firuza ABBASOVA, doctor of Law, professor, Baku State University

Rafail HASANOV, doctor of sociological sciences, professor, Baku State University

Elshad MIRBASHIR OGLU, doctor of political sciences, professor, Academy of Public Administration under the

President of the Republic of Azerbaijan

Shahla SAMADOVA, doctor of Law, professor, Baku State University

Shikar GASIMOV, doctor of historical sciences, professor, Azerbaijan Technical University

Museyib ILYASOV, doctor of pedagogical sciences, professor, Azerbaijan State Pedagogical University

Monsum ALISHOV, doctor of pedagogical sciences, professor, "Idrak" lyceum

Abbas ABBASOV, doctor of philosophy in philology, professor, Baku State University

Elchin HUSEYN, doctor of biomedical sciences, Azerbaijan State University of Oil and Industry

Rashid JABBAROV, doctor of psychological sciences, docent, Baku State University

Nariman SEYIDALIYEV, doctor of philological sciences, docent, Institute of Linguistics of ANAS

Durdana MAMMADOVA, doctor of philosophy in Law, docent, Baku State University 


\title{
HUMANITTAR Və İCTIMMAİ ELMLӘR BÖLMӘSİ
}

\author{
HUMANITIES AND SOCIAL SCIENCES SECTION
}

\author{
Qızxanım Nizaməddin qızı Qəhrəmanova \\ Azərbaycan Dövlət Pedaqoji Universiteti \\ psixologiya elmləri doktoru \\ qehremanovakonul@yandex.ru
}

\section{ANALITIKK PSIXOLOGIYADA UŞAĞIN İNKISSAFI PROBLEMI}

\author{
Açar sözlor: uşaq, şəxsiyyət, psixologiya, şüur, şüursuzluq
}

\section{The problem of child development in analytical psychology Summary}

Child psychology is one of the most studied areas of psychology. This field of science focuses on the development of cognitive, emotional and behavioral acts of children in prenatal development until adolescence, studies the dynamics of mental development. Child psychology deals not only with how children grow up, but also with the study of their development as individuals, as well as with the trends of social development. The study of child psychology has its own difficulties. At different times, the study of child psychology has aroused interest. For this reason, numerous psychological studies have been devoted to the development of the child's personality.

Key words: child, personality, psychology, consciousness, unconsciousness

\section{Giriş}

Psixologiyanın digər sahələrində aparılmış tədqiqatlardan fərqli olaraq uşaq psixologiyası mürəkkəb struktura malikdir. İnkişafın sürətli tendensiyası bu mürəkkəbliyi bir qədər də artırır. Bir çox psixoloqlar hesab edirlər ki, uşaqlıq dövrünün təcrübəsi o qədər önəmlidir ki, bu sonrak1 inkişafın əsas istiqamətlərini müəyyən edir. Uşaqlıq dövrünün həyatın qalan hissəsində bu qədər vacib rol oynadığına görə bu mövzu psixologiya, sosiologiya və təhsil sahəsində belə bir vacib bir mövzuya çevrildiyi təəccüblü deyil. Mütəxəssislər yalnız uşağın normal inkişafına kömək edən bir çox təsirə, eyni zamanda uşaqlıq dövründə psixoloji problemlərə səbəb ola biləcək müxtəlif amillərə diqqət yetirirlər. Bununla yanaşı uşaqların sağlam və uyğun şəkildə böyüməsinə, inkişafina kömək etməyə çalışan uşaq psixoloqları üçün uşaq psixologiyası böyük maraq doğurur. Uşaqların təlimi, tərbiyəsi, o cümlədən inkişafın psixoloji aspektləri və s. kimi problemlər uşaq psixologiyası sahəsində tədqiqat aparanlar üçün həmişə öndə dayanmışdır. Məhz bu baxımdan uşaq psixologiyası sahəsində bir-birinə oxşar, bir-birinə zidd yanaşmalar, müxtəlif fikirlər mövcud olmuşdur. Çoxsaylı tədqiqatçı psixoloqlar uşağın şəxsiyyətinin inkişaf dinamikasının fərqli izahını vermişlər. Bu baxımdan analitik psixologiyada uşağın inkişaf problemi xüsusilə diqqəti cəlb edir.

Uşaq şəxsiyyətinin inkişafında K.Yunqun konsepsiyası psixikanın energetika modelinə əsaslanmışdır. Onun fikrincə, insan psixikası özünə üç səviyyəni daxil edir: şüur, şəxsi şüursuzluq və kollektiv şüursuzluq. Bu konsepsiyaya görə uşaq şəxsiyyətinin inkişafinda həlledici rolu bəşəriyyətin keçmişindən qalmış hafizə izlərindən yaranan kollektiv şüursuzluq oynayır. $O$, insan şəxsiyyətinə təsir edir və anadan olduğu andan onun davranış tərzini müəyyənləşdirir. Kollektiv şüursuzluq özündə insanın və hətta insanabənzər nəsillərin də hafizəsinin gizli izlərini özündə birləşdirir. Yunqun özünün dediyi kimi "kollektiv şüurusuzluq" hər bir fərdin beyin strukturunda yaranan insan təkamülünün ruhi səltənəti durur.

Karl Yunq Z.Freydə nisbətən şüursuzun şüura komplementar münasibətini, müstəqil inkişafını və digər məzmunu (sıxışdırılıb çıxarılmış hadisələr, komplekslər, arxetiplər və s.) qeyd edərək daha 
geǹiş nəzərdən keçirir. Fərdi şüursuzluğun və şüurun məzmununun əlaqəsinin q1rılmas1 patologiyaya gətirib çıxarır. Fərdi şüursuza fərdin ontogenezi prosesində sıxışdırılıb çıxarılmış hallar-şüurdan ayrılan və başlıca olaraq şüursuzluq sahəsində sərbəst və müstəqil fəaliyyət göstərən komplekslər və ya "psixi hal qrupları (hisslər, həvəslər, xatirələr) daxildir". (3)

"Psixe"yenin sərbəst təbəqəsi - kollektiv şüursuz bəşəriyyətin uzaq əcdadlarından irsi qəbul etdiyi ümumi və daha qədim təcrübəsini ehtiva edən yaddaş növüdür. Onun tərkibinə ictimai mühitdən asılı olmayaraq hər bir insanda təzahür edən instinktlər, arxetiplər və ya insanların inanclarının, hisslərinin, hərəkət və meyllərinin proobrazları daxildir. Arxetip şüurun topladığ1 həyəcanları sistemləşdirməklə və onlara müəyyən forma verməklə müəyyən inkişaf anında aktivləşən meyldir (məsələn, allah haqqında təsəvvürlər, bir çox mədəniyyətlər üçün ritual ayinlər qruplaşdırılır və "üçlükdə” birləşdirilir (müqəddəs Üçlük simvolu). Yunqun fikrincə, arxetiplər qayğıkeș ananın, xeyirxah və ya qəzəbli atanın, müdrik qocanın və s. obrazlarıdır) (Jung K., 1976).

Psixikanın mərkəzi instansiyası şüurun və şüursuzun birləşmə nöqtəsində lokallaşan “Özümülkdür” (das Selbst). Özündən və ya transsendental şüurdan xarici aləmin təsiri altında "Eqo" ayrılır (psixikanın öz Məninin dərk edilməsini təmin edən strukturu). "Eqo" fərd üçün xoşagəlməz həyəcanları şüur sahəsindən fərdi şüursuz sahəsinə sıxışdırıb çıxarır və xarici aləmə uyğunlaşmanı asanlaşdırır.

Yunq eqonun xarici reallığa yönlənən hissəsini persona (maska) adlandırırdı. Persona insanın psixi və psixofizioloji cəhətlərini, həmçinin bütün qazanılan davranış etalonlarını əhatə edir. $\mathrm{O}$ ətrafin tələbləri və fərdin daxili tələbatları arasında "kompromis" yolu ilə sosial mühitə uyğunlaşmasını təmin edir. Lakin əgər fərd daim qazanılmış uyğunlaşma formaları pərdəsi altında öz həqiqi mahiyyətini gizlədirsə, o zaman "persona" altında insanın fərdiliyinin gizləndiyi əsil maskaya çevrilir."Eqo"nun "persona" ilə həddən artıq eyniləşməsi və "kölgə"nin böyüməsi yaranır. "Kölgə" fərdi şüursuz sahəsində olan və instinktlərdən ibarət olan "persona"nın əksidir. Hər bir fərd özünün ətrafdakılardan gizlədilən və həyatda sosial qəbul edilməyən hərəkətlərə görə məsuliyyət daşıyan "kölgə"sinə malikdir. K.Yunqun fikrincə, əsas psixi funksiyalar təfəkkür, hisslər, qavrama və intuisiyadır. Onlar iki əks cütlərdir.

Təfəkkür və hisslər qiymətləndirməyə əsaslanan rasional funksiyalardır (təfəkkür: həqiqi yalan, hisslər isə xoşagələn - xoşagəlməz). Qavrama və intuisiya irrasional funksiyalardır. Adətən sadalanan dörd funksiyadan yalnız biri daha çox inkişaf edir və differensiallaşır. İnsan reallıqda əsasən bu başlıca, dominantlıq edən funksiyanın köməyi ilə yönləndirilir və ona uyğunlaşır. Yunq bu nəzəri mühakimələr əsasında özünün psixoloji tiplər nəzəriyyəsini inkişaf etdirdi (Yunq K., 1924). Dominantlıq edən funksiya "psixe" şəxsiyyətin funksional tipini təyin edir (intellektual, intuitiv, sensor və s.). Daha ümumi tipoloji kateqoriyalar istiqamətlərin tiplərini müəyyən edir: ekstraversiya və introversiya.

Şəxsiyyətin ekstraversiya tipi artıq uşaqlıqda təzahür edir və xarici aləmin obyektlərinə yönlənməklə, introversiya tip isə daxilə, öz "Mən"inə yönlənməklə xarakterizə edilir. Lakin şüurun ekstravertiv istiqamətinin üstünlüyü şüursuzun introvertiv istiqamətini yaradır və ya əksinə. $\mathrm{Bu}$ psixi tarazlığ 1 təmin edir, ekstraversiyanın (isteriya) və ya introversiyanın (psixosteniya) yüksək formaları ilə təzahür edən psixi pozuntulara gətirib çıxarmır. (4)

Fərdi psixologiya nəzəriyyəsinin yaradıcısı Alfred Adler (Adler A., 1964) Z.Freydin bioloji determinizmdən, psixi pozuntuların seksual etiologiyası və fərdin həyatında şüursuzluğun üstün rolu haqqinda təsəvvürlər imtina edərək yeni bir yanaşma irəli sürdü. Onun fikrincə, insan öz təbiətinə görə ictimai varlıqdır və buna görə də onun hərkətlərini əsaslandıran əsas amil onun sosial tələbatlardır. Onlardan ən vacibi cəmiyyətlə əlaqə tələbatıdır. Bununla yanaşı, insan hər şeydən əvvəl şüurlu varlıqdır (yəni öz məqsədlərini, meyllərini, imkanlarını və qüsurlarını dərk edən). Şüursuzluq isə onun həyatında ikinci dərəcəli rol oynayır. Adlerin konsepsiyasına əsasən, artıq uşağın həyatının 4-5-ci ilində fərdin sosial məqsədlərə yönlənmiş fəaliyyət sistemi-həyat üslubu formalaşır və insanın fəaliyyəti keçmişlə deyil, gələcəklə şərtlənir.

İnsanın fəaliyyətini təyin edən ikinci vacib amil özünütəsdiq tələbatı, "üstünlüyə can atmaqdır". Hər bir insanda erkən uşaqlıq dövründə həm filogenetik (insanın növ kimi fiziki zəifliyi ilə), həm 
də`ontogenetik (uşağın köməksizliyi, onun böyüklərdən asılı olması və s.) baxımdan şərtləndirilən "natamamlıq hissi" formalaşır.

Natamamlıq hissi kompensasiyaya meyli, yəni öz çatışmazlıqlarının fəaliyyətin digər sahəsində nailiyyətlərlə tarazlanmasına meyli yaradır. Bəzən yüksək kompensasiya (ekvivalent termin hiperkompensasiya) - məhz natamamlıq hissinin səbəbi olan həmin çatışmazlığın dəf edilməsi cəhdi kimi təzahür edir. (1)

Natamamlıq hissinin ətraf sosial mühitin xoşagəlməz təsiri altında dərinləşməsi natamamlıq kompleksinin inkişafına gətirib çıxarır. Onunla iki əsas mübarizə üsulu mövcuddur: gücə meyl və nevrotik səviyyəli psixi patologiyanın inkişafına gətirib çıxaran "xəstəlikdən qaçış".

Analitik psixologiyanın on başlıca tapıntısı ruhun bioloji strukturunun izahını irəli sürmək olmuşdur. Həmçinin analitik psixologiya prinsiplərinə görə uşaq tərbiyəsində özünüdərk zəruri şərt kimi qəbul edilir. Hesab edilir ki, uşağın tərbiyə prosesində valideyn passiv tərəf olmamalı özünü tərbiyə vasitəsilə uşağın tərbiyəsinə təsir göstərməlidir.

\section{Notico}

Qeyd etdiyimiz kimi uşaq şəxsiyyətinin inkişafı psixologiyanın müxtəlif cərəyanları və məktəblərinin nümayəndələri tərəfindən araşdırılmışdır. Bu baxımdan analitik psixologiyanın banisi K.Q.Yunq və onun tərəfdaşları uşaq şəxsiyyətinin inkişafının müxtəlif istiqamətlərini tədqiq etmiş, inkişafın qanunauyğunluqlarını, mexanizmlərini və faktlarını ortaya qoymağı və günümüzədək fikirlərinin aktuallıqlarını qorumağı bacarmışlar. K.Q.Yunqun uşağın inkişaf məsələləri ilə bağlı fikirləri əsasən bir sual ətrafında toplanır: uşaqlara valideynlərinin davamçısı, onların təsiri olmadan formalaşmayan varlıq kimi, yoxsa müstəqil düşüncəyə, individual psixi inkişafa malik varlıq kimi baxmaq lazımdır.....? Burada bir tərəfdən valideynlərin "həqiqi" fiqurları ilə arxetip və digər tərəfdən təcrübənin qarşılıqlı təsirindən yaranan obrazlar arasındakı gərginlik ön plana çıxır.

Yunq, bir uşağın ana ilə münasibətində üç cəhəti müəyyənləşdirdi. Birincisi, böyümək müddətində onunla və ya imicinə görə regresiya baş verir. İkincisi, anadan ayrılıq bir mübarizədir. Üçüncüsü, yemək çox vacibdir.

Ataya gəldikdə isə, Yunq aşağıdakı mövzuları nəzərdən keçirir: ata ananın əksinə - bütün dəyərlərin və xüsusiyyətlərin təcəssümü; mənəvi prinsipi təmsil edən "məlumat verən ruh" olaraq təqdim olunur. Ata Tanrının səviyyəsinə və nüfuzuna qaldırılmış, oğul üçün şəxsiyyət nümunəsi olaraq, q1zı tərəfindən ilk "sevilən" ata və animus obrazı olaraq göstərilir.

\section{Odəbiyyat}

1. Alferd Adler.yaşamaq sənəti (Tərcümə). Bak1: 2017, $230 \mathrm{~s}$.

2. Bayramov Ә.S. Әlizadə Ә.Ә. Psixologiya. Bakı: 2003, 540 s.

3. Коломинский Я.Л., Панько Е.А., Игумнов С.А.. Психическое развитие детей в норме и патологии: психологическая диагностика, профилактика и коррекция - СПб.: Питер,2004,480 с.

4. Теории личности: познание человека. С.Клонингер. СПБ: Питер, 2003, с. .103

5. Обухова Л.Ф. Детская возрастная психология: Учебное пособие для вузов. М.: Педагогическое общество России,2000, 443 с 


\title{
Şərəbanı Oli qızı Məmmədova
}

Naxçıvan Dövlət Universiteti

filologiya üzrə fəlsəfə doktoru sherebani@gmail.com

\section{NİZAMI GəNCəVINIIN FİKİR DÜNYASINDA SÖZÜN Və MÜTALİəNIN DəYəRİ}

\author{
Açar sözlor: mütalia, kitab, kitabxana, Xəmsə, novator, kəlam \\ The value of words and reading in Nizami Ganjavi's world of thought \\ Summary
}

The article analyzes Nizami Ganjavi's views on the value of words and the importance of reading in his works. In the poet's mind, the perfection and integrity of the human personality is the value of his words. Nizami considers the word the basis of creation, the world, sees the word in the yeast of everything. The genius poet points out that the creation of the world consists of the first word, the creation of mankind by God with the command "Be." The role of reading in the formation of Nizami's personality is highly appreciated. The article explores the importance of these thoughts of the poet for the modern period.

Key words: reading, book, library, Hamsa, innovator, word

\section{Giriş}

Qüdrətli qələm sahibi, "söz mülkünün sultanı”, dahi Azərbaycan şairi Nizami Gəncəvinin yaradıcılığ bütün parametrlərinə görə bəşər tarixində qlobal hadisədir. XII əsrəqədərki elmi, dini, ədəbi-mədəni dəyərləri özündə bir məcmu halında birləşdirən, əsrlərdən bəri sevilə-sevilə oxunub bu gün də ürəkləri fəth edən Nizami ədəbi irsi bəşəriyyətin bədii fikir salnaməsində yeni parlaq səhifə açmış, özündən sonra böyük ədəbi məktəb yaratmışdır. Öz ecazkar söz sənəti ilə Nizami Gəncəvi dövrünün bütün elmlərini şeirə gətirmiş, ədalət və bəşəri hissləri tərənnüm etmiş, ən əsası insana hörmət və humanizm ideyalarını ölməz "Xəmsə"sində açıb göstərməyə nail olmuşdur. Digər tərəfdən dahi şairin rəvan dili və onun şairlik qabiliyyəti buna rəvac vermişdir. Heç şübhəsiz ki, nə özündən əvvəlki sələfləri, nə də ondan sonrakı xələflərinin heç biri hələ sağlı̆̆ında "Dahi", "Mütəfəkkir", "Filosof”, "Həkim” və "Şeyx" kimi ali titulları ala bilməmişdir. Şərq ədəbiyyatına Nizami Gəncəvinin təsir qüvvəsi daha bariz şəkildə özünü göstərir. Təkcə onu demək kifayətdir ki, yüzdən artıq şair Xəmsə yaratmağa çalışsa da, Nizamiyə çatmamışlar. Bunların içərisində böyük özbək şairi Olişir Nəvainin türkcə (özbək türkcəsi) yazdığı Xəmsə qənaətbəxşdir. Ә.Nəvai dönədönə Nizamini özünə layiqli müəllim hesab edir. Onu qeyd etmək yerinə düşər ki, Şərqdə böyüklükiçikli 400-dən artıq "Leyli və Məcnun" adlı dastan, hekayə və məqalə yazılmışdır. Bu da Nizami təsirini aydın şəkildə göstərir. İran ədəbiyyatşünaslığında elə bir şair, yazıçı, ədəbiyyat tədbirlərində məruzəçiyə rast gəlinməz ki, Nizamidən söz açmasın. Onu demək kifayətdir ki, indiyə qədər 500 nəfərdən çox alim Nizami yaradıcılığına baş vurmuş, onun xəmsəsinin ingilis dilində dünyaya yayılmasına nail olmuşdur. Nizami yaradıcılığı səkkiz əsrdən artıqdır ki, xalqımızın mənəviyyatının ayrılmaz hissəsinə çevrilmişdir. İnsanları daim əxlaqi kamilliyə çağıran və yüksək mənəvi keyfiyyətlər aşılayan zəngin yaradıcılı̆̆ simalardandir. Nizami yaradıcılığı bir ümmandır ki, onda elmin bütün sahələrinə aid istənilən fikri tapmaq olar. Yaratdığı zəngin söz ümmanında mütəfəkkir şair elmin, sözün dəyərini layiqincə vermiş, dünya söz xəzinəsinə yeni, "bakir" söz yaratmışdır. Nizami sözü-nitqi-dili insanın daxili aləmi hesab etməkdən əlavə, onu başqa canlılardan fərqləndirən, bütün yaranmışların əşrəfi edən, hətta onun varlığına, canına bərabər bir anlayış hesab edir. " Sirlər xəzinəsi "əsərində oxuyuruq:

Söz eşqin lüğətində öz canımızdır bizim,

Biz-sözük, görkəmimiz-eyvanımızdır bizim /Nizami Gəncəvi(1), 2004: 58/

"Xosrov və Şirin"-də buna bənzər fikri şair belə ifadə edir: 
Söz Ruhdur, can üçün ruh bir dərmandır, Cantək əzizliyi bəlkə bundandır /Nizami Gəncəvi (2), 2004: 65/

Sözə bu qədər dəyər verən Nizami onu yaradılışın, dünyanın əsası hesab edir, hər şeyin mayasında sözü görür. Dahi şair dünyanın yaradılışının ilk sözdən ibarət olması, Tanrı tərəfindən "Kun -Ol” əmrilə bəşəriyyətin yaranmasına işarə edir. Deməli Yaradan hər şeydən əvvəl sözü yartmışdır. Yalnız həiqəti axtaranla və tapanlar böyük söz yaratmağa, bu sözün sayəsində yaşamağa qadirdirlər.

Söz olmasa yerində dünya donardı sözsüz,

Nə qədər söz dedilər, yenə əksilmədi söz.

İlk dəfə tərpənəndə sözdən güc aldı qələm

Sözdən doğuldu ilk hərf ... şahiddir bütün aləm

Xəlvət pərdəsini qaldırdılar, atdılar

Öncə söz cilvələndi. Sözdən can yaratdılar

Nizami Gəncəvi(1), 2004:, 58).

Şairin fikrincə "söz dirilik suyudur", cahanın - şah damarını açan, onu təzələyən sözdür. Söz Tanrının "Kun -Ol” əmri, candakı şah damar isə ruhdur. Kələfin ucu maddi aləmdir. Şairin fikrincə Tanrı neməti söx olmasaydı ruhu və bu maddi aləmi tapmaq olardımı? Sözün qüdrətilə yaradılan möcüzələr başqa yolla mümkün deyil. "Ölsək, sözlə ölərik, qalsaq, sözlə qalarıq" - deyən şair insan şəxsiyyətinin kamilliyini, bütövlüynü onun sözünün dəyərində görür, sözü q1zıldan qiymətli hesab edir:

Mədən söz və q1z1lı təklif edib sərrafa,

Sərraf tərəzisində söz qizıldan çox baha!

Təzə söz, köhnə altun... hansı hakim kəsilir?

Söz hara, q1zıl hara? Bunu sözdoğan bilir!

Öz qüvvəsilə gedər söz qasidi... tövşüməz,

Söz qaldıran dağları qaldıra bilməz heç kəs.

Söz gümüşü yanında qara torpaqdı dirhəm,

Q1zıl hansı itdir ki, onu sözə tay biləm?

Nizami Gəncəvi (1), 2004: 58 /

Yaxud;

Q1zılı saymaqda, bil ki, səhvin var,

Dünyanın gözünü ağıl parladar

Nizami Gəncəvi (4), 2004: 43/

Sözə bu qədər dəyər verən mütəfəkkir hər əsərində ifadə etdiyi bu cür fikirlərin haqqını öz qələmi ilə verir, şairin, söz sərrafının məsuliyyətlərini on plana çəkir. Ölçülüb-bişilməmiş, dağınıq sözlərdən uzaq olmağı, hər sözə zərgər qəqiqliyi ilə yanaşmağı tələb edir. Hətta həqiqi sənətkarı, cilvəli söz ustaslarını- "sözdoğanları nur saşan peygəmbərin kölgəsi hesab edir. Hər iki aləmin xəzinəsini bəşərin üzünə açan, onu dünya və axirət sirlərinə vaqif edən haqq yolunun ərləri, ərşin bülblləridir.

Orşin bülbülləridir cahanda söz qoşanlar,

Məgər özgələrinə tay tutularmı onlar?

Sözdoğanlar-nur sacan peyğəmbərin kolgəsi,

Orzin işıq pərdəsi, haqqin yanar nəfəsi.

Mətanət meydanında kimlər tutdu gör səfi,

Әvvəlcə peyğəmbərlər, sonra şairlər səfi

Nizami Gəncəvi(1), 2004: 61/

İstedadlı şairi söz bəstəkarı hesab edən Nizami hökmdar qarşısında deyil, yalnız sözün qarşısında diz üstə çökməyi qəbul edir. Sözünün, yaratdığı əsərin qüdrətilə söz köhləninə qalxan, dünyaları, ölkələri fəth edən şair hökmdardan üstündür. Qələm və şahlardan fərqli olaraq q1lınca və orduya ehtiyac hiss etmədən ürəkləri, ölkələri tutmağa qadirdirlər. Bu səbəbdən onlar məğrur və əzəmətlidir, heş bir şahın qarşısında baş əyməzlər. 
Kimin söz pərdəsində ahəngi var, sehri var,

Özü yerdə olsa da, ruhu göylərdə yaşar.

Dizi üstə söz yazıb, ölkələri tutan kəs

Dünyada heç bir kəsin qapısında baş əyməz!

Nizami Gəncəvi (1), 2004:179)

Şairin fiziki ömründən başqa mənəvi dünyası da var. Sənətkarın hörmətini, nüfuzunu ucaldan yalnız öz poeziyasıdır. Yalnız böyük poeziya sayəsində o, göyün yeddincimqatında yerləşən əfsanəvi Sidr ağaçı mövqeyinə yüksələr, dünyanın ən uça qatında sultanlardan, şahlardan belə yüksək məqamda, daha da əzəmətli görünər.

Şerin qaldırar səni, Sidrdə əyləşdirər,

Sənə ən uca qatda şahlıq, sultanlıq verər.

Nizami Gəncəvi(1), 2004: 63/

Nizaminin yaşadığı dövr böyük elmi kəşflər, ağıl və idrak dövrü idi. Orta əsrlərin dini ehkamına, mövhumatına İntibah ağl1-kamalı qarşı qoyurdu. Nizami də İntibahın on böyük nümayəndələrindən biri kimi ağıl məsələsinə xüsusi diqqət yetirir, insanın özünü dərk etməsində onun rolunu, ağlın insana arxa olduğunu yazır. Ağıllı adamı mələk adlandırır, ağıllı insanda yerlə göyün birləşdiyi fikrini irəli sürür.

İnsana arxadır onun kamalı,

Ağıldır hər kəsin dövləti, malı.

Kim ki yetişmədi ağıldan bara,

Oxşar insansifət əjdahalara.

Zirək adam, insan mələkdir, mələk.

Zirəklik gözəldir, əcəbdir, gerçək.

Nizami Gəncəvi (4), 2004: 9/

Yaxud;

Məna yolunda yürü, bilik başın tacıdır,

Bil ki, qanan bir düşmən qanmaz dostdan yaxşı1ır.

Nizami Gəncəvi(3), 2004: 179/

Xosrov və Şirin"də Nizami sözün təsir gücünü, tərbiyəvi əhəmiyyətini yüksək qiymətləndirir, insanı kamilliyə aparan yolda əsas vasitə olduğunu önə çəkir. Şair Xosrovla Fərhadın deyişməsində də hökmdarın deyil, Fərhadın sözlə qələbəsini əks etdirir. Mənəviyyatca cılız, həyata oyun-oyuncaq kimi baxan Xosrovu Şirinin öyüd -nəsihəti, müəllimi Büzürgümidin "Kəlilə və Dimnə"dən danışdığı qirx hekayət ilə dəyşdirir, mənən kamilləşməsinə, yekin bir şəxsiyyətə çevirlməsinə kömək edir. Osərin sonunda Xosrovun dünya, həyat, mənəviyyat məsələləri ilə maraqlandığını, alim və bilicilərin məsləhətlərini dinlədiyinin, dövlət işlərində ədalətli bir şah olduğunu görürük. Bütün bunlar "varlığın anasının sözdən gözəl övlad doğmadığını" deyən dahi söz ustasının elmə biliyiə, sözə və mütaliəyə nə qədər dəyər verdiyinini göstərir.

Sözün dəyəri, təsir gücü, insanı kamilləşdirməsi yolun da ifadə etdiyi dəyərli fikirləri dahi şair oğlu Məhəmmədə nəsihətində də aydın, ibrətamiz dillə ifadə edir. "Xosrov vəŞirin" əsərində "Bilik kəsb etməklə dünyanı qazan" deyən şair "Leylivə Məcnunda" övladına elmlərə vaqif olmağ1, kamilləşmək yolunda elmi mütaliəni əsas sayır. Bu sözlər ağsaqqal nəsihəti ata öyüdü kimi bu gün əhəmiyyətlidir

Ucalmaq istəsən, bir kamala çat,

Kamala ehtiram göstərər həyat.

Səadət kamalla yetişir başa,

Xalqa hörmət elə, ədəblə yaşa.

Elmlər elmidir demiş peyğəmbər

Din elmi, təbabət elmi müxtəsər.

Bir elim öyrənmək istədikdə sən

Çalış ki, hər şeyi kamil biləsən.

Kamil bir palançı olsa da insan, 


\section{Yaxşıdır yarımçıq papaqçılıqdan.}

Nizami Gəncəvi(3), 2004: 51- 52/

İnsanın kamilliyə aparan yolda kitabın, mütaliənin qiymətini verən şair oxunulan hər əsərin insanları səadət yoluna çıxaran vasitə kimi qiymətləndirir.

Hər kim öyrənməyi bilməyirsə ar,

Sudan dürr, daşdan da gövhər çıxardar.

Ancaq öyrənməyi ar bilən insan

Məhrumdur dünyada bilik almaqdan.

Çox iti zehinlər yatan oldular,

Axırda saxs1 qab satan oldular.

Təlimə həvəskar çox korazehin

İqlimlər qazisi olmadı? Deyin.

Təlimdir düzəldən ipləri sap tək,

Olmazmı cəhd etsə bir insan mələk?

Nizami Gəncəvi (4), 2004: 49/

Şair öz qəhrəmanlarını mütaliə edən, alimlərin əhatəsində olan, müəllimlərinin öyüd nəsihətləri ilə kamilləşən obrazlar kimi təqdim edir. Dünyanı fəth edən İsgəndər mütaliəyəciddi fikir verir, uzaq səfərlərə çıxarkən özü ilə kitablar aparır, ələ keçirdiyi ölkələrdən qiymətli kitabları toplayıb gətirir, onları tərcümə etdirir, yeni kitabxanalrın yaradılmasına çalışır. Kİtabı xəzinələrə bərabər tutan İsgəndər:
Omr etdi: tez gəlsin, atlansın vəzir.
Orda kitabxana varsa nə qədər,
Işarə elədi, tez gətirsinlər.
Hər çeşid elmdən dəyərli sözlər,
Hər incə hikmətdən açdı bir dəftər.
Yunana göndərdi tərcüman ilə
Çevirsin bir dildən başqa bir dilə.
Padşahın əmriylə gəldi Orəstu,
Durmadan at çapsın Yunana doğru.
Rövşənək xanımı alsın bərabər,
Götürsün xəzinə, kitab və dəftər.

Nizami Gəncəvi (5), 2004:, 201/

Kitabı dürr, kitabxananı dürr ümmünı, bilik xəzinəsi adlandıran şair bu fikirləri ilə əsrlərdən bəri öz elmi və təcrübi əhəmiyyətini saxlayan fikir, dünyagörüş kimi onları bəşəriyyətin ən vacib inkişaf vasitəsi, kəşfi hesab etmişdir.

Dünya dilərində nə var cahanda

Buyurdu tərcümə edilsin bütün

Bilik xəzinəsini dodurmaq üçün

Dürr yığdı elm üçün bir-bir hər yandan

Bunlardan yaratdı böyük bir ümman.

Nizami Gəncəvi (5), 2004: 430/

Professor A.Xələfovun sözləri ilə desək: “dünyanın görkəmli alimləri, mütəfəkkirləri, filosofları şairləri və yazıçıları kitabın və kitabxananın şəninə, şöhrətinə qiymətli fikirlər irəli sürmüş, söz söyləmiş, kəlamlar yaratmışlar. Ancaq dahi Nizaminin kəlamları bunların işərisində bir zirvə kimi parlayır və əsrlər keçdikcə parlaqlığını artırır. /Xələfov,2004: 156/

Sözün də su kimi lətafəti var,

Hər sözü az demək daha xoş olar.

Bir inci saflığ varsa da suda,

Artıq içiləndə dərd verir su da.

Inci tək sözlər seç, az danış, az din,

Qoy az sözlərinlə dünya bəzənsin. 


\title{
Az sözün inci tək mənası solmaz,
}

Çox sözün kərpic tək qiyməti olmaz.

Nizami Gəncəvi(3), 2004: 52-53).

Öz dövrünün bütün elmlərini kamil bilən Nizami oxumağın, mütaliə etməyin kamil nümunəsi olmuş, əsərinin dəlilli-sübutlu olması üçün mənbələrə biganə qalmamışdır. Məsələyə nə qədər ciddi yanaşdığını, uzun müddət mövzu ilə bağlı nə qədər axtarışlar apardığını şair özü də aydın dillə dəqiq şəkildə qeyd edir, istifadə etdiyi mənbələrdən bəzilərinin adlarını çəkir:

Dünyada nə qədər kitab var belə,

Çalışı əlləşib gətirdim ələ.

Orəbcə, dəricə, yeri düşərkən,

Buxari, Təbəri əsərlərindən,

Oxudum, oxudum, sonra da vardım,

Hər gizli xəznədən bir dürr çıxardım.

Olimə yetişən hər bir varaqdan

Nüsxələr bağladım mən zaman-zaman.

Nizami Gəncəvi(4), 2004: 30-31).

Azərbaycan kitab tarixini araşdırıcıları professor A.Xələfov, İ.Zəkiyev XII əsrdə Gəncədə "Dar əlkitab" adlı böyük kitabxananın fəaliyyət göstərməsini, burada 10-dan çox xarici dildə əlyazmaların olmasnı qeyd edirlər. /Xələfov, 2004: 156/ Həmçinin şairin dayısı Xacə Ömərin Bərdə kitabxanasında çalışması faktı Nizaminin zəngin mütaliə imkanlarının olmasını təsdiqləyir.

Nizaminin novatorluğu heç də mənbələr üzərində işləməklə, onların içindən tez ideya-bədii qayəsinə uyğun məlumatlar çıxarması ilə məhdudlaşmır. Şair öz əsərlərinin yüksək sənət nümunəsi olduğunu bilir və səmimi hisslərlə (fəxr xatirinə yox!) onların gizli sirlərlə dolu olduğunu bəyan edir:

Belə bir dəyərli gövhərlə, dostlar,

Bir gövhər sevənə ehtiyacım var.

İstərəm eylə bir kamil dinləyən,

Şairlik sirrim öyrənsin məndən! /Nizami Gəncəvi(5), 2004: 9/

\begin{abstract}
Notico
Öz əsərləri iə insanların həyat yollarını işıqlandıran, çətin işlərini asanlaşdıran böyük elm və hikmət sahibi kimi Nizaminin fikrincə insanı heç bir rütbə yox, yalnız elm, bilik, dəyərli söz yaşadacaq!

Tanrı yaratmışsa hər nə, yaxşı bax,

Sözdən başqa bir şey yaşamayacaq.

İnsanın qalacaq sözü yadigar,

Yeldir yerdə qalan başqa hər nə var. /Nizami Gəncəvi (4), 2004: 40/

Bu mövzunun araşdırılması Azərbaycan mədəniyyətinin öyrənilməsi işində bu gün xüsusilə mühüm əhəmiyyət daşıyır. Nizami dövrü, ədəbi irsi və məktəbi problemləri müasir humanitar düşüncənin tələbləri kontekstində və azərbaycançılıq məfkurəsi işı̆̆ında tədqiqini gözləyir. Böyük iftixar hissi ilə deyə bilərik ki, Nizami bu göstəricilərinə görə təkcə Azərbaycan xalqının deyil, ümumbəşəri şair olaraq bəşəriyyətin qəbul etdiyi bir simadır. Onun hər misrasından qopan öyüd və nəsihətləri bəşər övladı canlandıqca həmişəyaşıl ağac kimi əbədi yaşayacaqdır.
\end{abstract}

\section{Odəbiyyat}

1. Nizami Gəncəvi. Sirlər xəzinəsi. "Lider nəşriyyat", Bak1, 2004, 264 s.

2. Nizami Gəncəvi. Xosrov və Şirin. Bak1, "Lider nəşriyyat", 2004, 392 s.

3. Nizami Gəncəvi. Leyli və Məcnun. Bak1, "Lider nəşriyyat", 2004, 288 .

4. Nizami Gəncəvi. Yeddi gözəl. Bak1, "Lider nəşriyyat", 2004, 336 s.

5. Nizami Gəncəvi. İsgəndərnamə. Şərəfnamə. Bak1, "Lider nəşriyyat", 2004, 432 səh.

6. Xələfov A. Azərbaycanda kitabxana işinin tarixi (Đn qədim dövrdən XX sərə qədər): Dərslik I hissə B, Bakı Universiteti nəşriyatı 2004. 328 səh. 


\title{
İNANCLARDA MIFOLOJİ OBRAZLARIN YER TUTMASI (Naxçıvan materialları əsasında)
}

\author{
Açar sözlor: obraz, mifologiya, funksiya, su inancl, bad ruh

\section{Marking of image function (on base of Nakhchivan maerials) Summary}

Mythological images in faith system are dealt with in the paper. The place and function of images in threefold system are defined, and the marking level on base of comparisons is appeared. Occupying a wide place the mythological images in faiths remarked from Nakhchivan are drawn into attention.

Key words: image, mythology, function, water faith, evil ghost

Etnik-mədəni ənənənin özünəməxsus layı olan inanc sistemində mifoloji obrazlar fərqli boy verir. İnanca görə, göy aləmi ulu Tanrının, xeyirxah ruhların məskənidir. Yerin üstündə insanlarla yanaşı əyələr də vardır. Yeraltı dünya adamlara zərər verən, zəfər toxunduran, demonik özəllikləri olan acıqlı ruhlarla doludur (6, s. 187). Kalmıklar da inanırlar ki, yuxarı dünyada Tanrı, eləcə də gözəl insanlar, aşağı dünyada isə pis ruhlar olur (10, s. 166). Bu düşüncə "sən göydən düşmüsən?" və ya "mən yerdən çıxmışam?" deyimlərində də yaşamaqdadır. Bu mühitdə ruhların görünüşü, varlığ1 da qəribə bir "dəqiqliklə” təsvir olunur. Altaylar suyun ruhunu ağ, torpağın ruhunu yaş1, günəşin ruhunu sarı, odun ruhunu isə qırmızı olaraq təsəvvür edirlər (9, s. 50). Tofaylarda, dunkanlarda dağ ruhu Haya İçite, ev ruhu Erge Sıp İçite, ağac-daş ruhu Mas-Tass İçite adlanır (10, s. 172). Cənubi Azərbaycanda göy, göyün ruhu en, yer, yerin ruhu ki adlanır (10, s. 35). Bizdə ənkə babaya and içilir. Çox ehtimal ki, ənkə baba yerin-göyün (yer ruhunun, göy ruhunun) birliyindən yaranmış obrazdır. Onkə babaya and içilməsi, onun köməyə çağırılması, kiminsə ənkə babasının lənətlənməsi, yəqin ki, müəyyən vəziyyət və münasibətlərlə şərtlənir. Xett mifologiyasında yeraltı dünyanın allahı Yelvani adlanır (11, s. 48).

K.Vəliyev yazır: "Dağlara, daşlara, torpağa, ağaclara sahib olan ruhlar istisnasız xeyirxah ruhlardır, insanlara kömək edirlər. Onlara yizim piy deyilir.

... Xeyirxah ruhlar da yeri gəldikdə insanı cəzalandırır, xəstəlik göndərir və s.” (14, s. 72).

Qərbi Sibir tatarlarında meşə əyəsi piçen, piçan, peşan, enperi, urman iyase (11, s. 316), su əyəsi kazan, Qərbi Sibir tatarları və qazaxlarda su iyesi, tatarlarda kişi - su babası, qadın su anası (11, s. 474), karaçaylılarda sun anası, kamuklarda suvanası (11, s. 471) adlanır. Ağac, ot əyəsini ereke adlandıran yakutlar onu torpaq əyəsi An darxan xatunun övladı (11, s. 669) hesab edirlər. Yakutlarda atəşin və ocağın sahibi "yiyəcəyi quru odun, yatağı qurumla qaralmış, yatağı köz, yorğanı kül olan ağsaçlı bir qadındır (13, s. 517). Qədim türklərdə odun qarşısında bıçaqla ət doğramaq, oda bıçaq göstərmək günah sayılırdı. Bıçaqla, dəmirlə ocağı qarışdırmaqla odun yaralanacağına inanılırdı. Ocağı su ilə söndürmə büs-bütün yasaq sayılırdı (13, s. 519-520).

Naxçıvanda yayılan inanclarda bu ənənələrin mühafizəsi diqqəti çəkir. Burda inanılır ki, odun üstünə su tökəndə od əyəsinin açığına gələr, sənə sədəmə toxundurar (2, s. 20). Deməli, ocağ1 su ilə söndürməyin yasaq edilməsi od əyəsi ilə şərtlənir. İnanclar cərgəsinə bu müstəvidən yanaş1lsa, odun qarşısına bıçaqla çıxmağın, ocağı dəmirlə qarışdırmağın günah sayılmasının da səbəbini od əyəsi ilə əlaqələndirmək lazım gəlir.

Naxçıvanda deyirlər ki, ocağa tüpürmək, üstünə su tökmək, ya da ayaqlayıb söndürmək olmaz. Yoxsa ocaq sahibinin acığına gələr, adama zəfər toxundurar (2, s. 16). Göründüyü kimi, eyni və oxşar inanclar od əyəsi, ocaq sahibi kimi təqdim olunan obrazla six əlaqələndirilir. Әуə, sahiblə 
bağlı düşüncə çox yayğındır. Burda deyilir ki, kimin həyətində qoyun varsa, hər gecə onun üstünə yeddi dəfə nur gələr. Qoyunun yiyəsi pak adam olmazsa, nur evin dövrəsini firlanıb qayıdır (2, s. 17). Gəlmək, firlanmaq, qayıtmaq canlıya məxsusdur. Deməli, gələn nur düşüncədə canlı olaraq (sahib kimi) qəbul edilir. Onun pak olmayanların yanından geri qayıtması da obrazın funksiyasını işarələndirir. Mətnlərin birində deyilir ki, keçi olan yerə hal anası getməz. Hətta keçi qəzili olan yerdə də görünməz (3, s. 33). Hər iki inancın yaratdığı qənaətdə ortaq nöqtələr vardır. Deməli, qoyun-keçi olan yerə xeyirxah ruhlar gələr. Onlar üçün paklıq, təmizlik vacib şərtdir. Bunun üçün qoyun-keçi olan yerə bəd ruhlar gəlməz.

Naxçıvanda inanılır ki, həftənin birinci günü ağac kəsmək günahdır. Həmin gün ağacların ruhu ziyarətə gedir. Həmin gün kim ağac kəssə, ağacın ziyarətdən qayıdan ruhu ona sədəmə vurar (3, s. 34). Mətndə inanclar mərhələli şəkildə reallaşır, bu mərhələlər ciddi semantik əlaqələrlə bağlanıblar:

1. Birinci gün ağac kəsmək qorxuludur;

2. Birinci gün ağacların ruhu ziyarətə gedir;

3. Ziyarətə gedən ruh həm də geri qayıdır (deməli, canlıdır);

4. Ziyarətə gedən ruh kəsilən ağacı da, ağackəsəni də görür (deməli, canlıdır);

5. Ağacın ruhu gördüyünü yaddan çıxarmır, nə vaxtsa ağac kəsənə ziyan vurur;

Deyirlər ki, evdə adam olsa da, olmasa da içəri girəndə salam verərlər. Deyərlər, evdə kimsələr var. Onlar evə xeyir-bərəkət gətirir, qaranquş-filan donunda adamın yuxusuna girir (2, s. 16). Göründüyü kimi, mətndə ev əyəsi kimsələr adı ilə işarələnib. Tədqiqat göstərir ki, mifoloji obrazların gözə başqa donda görsənməsi də ənənədən gəlir. Məsələn, məleykələrin də bəzən ilan donunda gözə görsənməsinə inanılır. Görənlər də onu tanımır, ilan bilir, vurub öldürür. O biri tayı da buna görə evdəkilərə zərər verir (3, s. 33). Göründüyü kimi, əyələr (sahiblər) xeyirxahdırlar. Onlar xoşbəxtlik, ruzi-bərəkət gətirirlər. Onların əsas funksiyaları budur. Müəyyən vəziyyətlərdə zərər vurub, sədəmə toxundururlar. Naxçıvanda inanılır ki, əyələrin içində ən üstünü su əyəsidir. Deyilir ki, su əyəsi suyun başında olur. Sudan addıyanda gərək suyun başına baxasan, yoxsa zərər çəkərsən. Göründüyü kimi, əyələrlə əlaqəli inanclarda zərər çəkmək müəyyən vəziyyətlərdən irəli gəlir. Başqa bir mətndə isə semantik dairə bir az da genişlənir: "Su əyəsi suda yaşayır. Suyun qırağında da bizdən yeylər yaşayır. Gəlib su əyəsinə salam verirsən, əyilirsən su içməyə. Bizdən yeylərin acığı tutur ki, bu niyə su əyəsinə salam verdi, bizə vermədi. Ona görə də sən əyiləndə arxadan vurur. Xəsdəlih tapırsan" (3, s. 25). Eyni düşüncə strukturunda su əyəsi bizdən yeyləri də həmin müstəviyə çıxarır. Yaxş1-yaman qoşalığı bu obrazlarla gerçəkləşir. Yeylər su əyəsi ilə mübarizəni çox dərin qatlarda aparırlar. Qarşıdurma birbaşa deyil, müəyyən vasitələrlə reallaşır. Zərər vermək, incitmək yeylərin funksiyasında əsas şərtlərdəndir. Mətnin məntiqinə görə, burda edilən yamanlıq (arxadan vurmaq) su əyəsinə verilən salama görədir. Guya su əyəsinə salam verilməsə idi, ya hər ikisinə salam verilsə idi, zərər vurulmayacaqdı. Su əyəsinə salam vermək yeylərə hörmətsizlikdir və s. Halbuki ənənədə yeylərə salam verilmir. Nə olursa-olsun, yeylər bu pisliyi edəcəkdilər.

Onənədə yaxş1-yaman qütblərinin bu cür təqdim olunması səciyyəvidir. Məsələn, Naxçıvandan toplanmış su ilə bağlı inanclarda çay qarısı, çay anası obrazları vardır. Çay qarısı pislik edir, hər kəsi yoldan çıxarır. Çay anası isə xeyirxahdır, hər kəsə yaxşılıq edir. Həmin inanclarda yaxşı-yaman qütbləri bu obrazlarla işarələndirilir. Kazan, Qərbi Sibir türklərinə, karaçaylara görə, su anasına hörmətsizlik edilsə, quraqlıq olaq, xəstəlik gələr (7, s. 30). Göründüyü kimi, bu, yamanlıq kimi yox, hörmətsizliyin nəticəsi kimi düşünülür. Naxçıvanda deyilir ki, suya salam verməsən, sənə qarğış edər, suyu hədər yerə qaynatmaq günahdır, su adamı nalə edər (2, s. 27-28). Digər inanclarla müqayisələr aparmaqla bu mətnlərdə su əyəsi, su anası obrazlarını asanlıqla bərpa etmək olar. B.Ögel çayların, suların qədimdə canlı varlıq olaraq düşünüldüyünü qeyd edir (13, s. 379). Suyun hədər yerə qaynadıldığının günah hesab olunması, bu zaman suyun nalə edəcəyinə inanılması, onun canlı varlıq olaraq düşünülməsinin izlərinin yaşadılmasıdır. Su içəni vurmazlar, su içəni ilan da vurmaz, pis yuxunu suya danışarlar, qaynar suyu yerə atmazlar, qorxan adama su verərlər kimi inanclarda suya münasibətin bir çox istiqamətləri sistem təşkil edir. Dunkanlarda su qablarının ağzı 
örtülür, inanca görə, şeytan açıq qablara girə bilər (9, s. 127). Eləcə də Naxçıvanda deyilir ki, suyun başına gedəndə salam vermək lazımdı. Suda Qarı nənə adlı bir şəxs yaşayır. Әgər ona salam verməsən, acığı tutar, sənə zəfər toxundurar (2, s. 16). Bu mətnin əsasında demək olar ki, su əyəsi burda Qarı nənə obrazında düşünülür. Bu obrazlar sırasında su adamı da vardır. "Arazda su adamı var. Səhər tezdən təh suya gedən görər. Aşağısı balıxdı, yuxarısı adam. Hətta daşlarda oturmağın da görüblər" (3, s. 27). Onun aşağısının balıq, yuxarısının adam kimi təsəvvür edilməsi mifoloji şüurun məhsuludur. Bir məqama da toxunmaq yerinə düşər. Tanrıçılığın islamla əvəz olunmasından bəhs edərkən M.Cəfərli yazır: "İslam sakral obrazları tanrıçılıqda mövcud olan obrazların yerini tutmuşdur" (8, s. 117). İnanclarda da belə bir transformasiya gerçəkləşmişdir. Məsələn, Naxçıvanda Arazın sakit axmasına bu konteksdən yanaşılmışdır: "Fatmeyi-Zəhra xanım Araz qırağında namaz q1lırmış. Deyillər ki, Arazın səsi onu narahat edir. Xanım üzünü Araza tutub səsin batsın, - deyir. O vaxtdandı ki, Araz sakit axır” (2, s. 29). Göründüyü kimi, Tanrı-Allah, ibadət-namaz, müqəddəs ana-Fatmeyi Zəhra xanım, bəddua-qarğış səviyyələrində transformasiya baş vermişdir.

İnanclarda pis ruhlar müxtəlif adlarla işarələndirilir. Türk xalqlarında inanılır ki, pis yer ruhları, əsasən, ağac köklərindən və budaqlardan yer üzünə çıxarlar (13, s. 21). B.Ögel qara gecəni yeraltı ruhlardan birinin adı olaraq göstərir (13, s. 265). C.Bəydili dönərgəliyi, yarımçıqlığı, axsaqlı̆̆ yeraltı dünya güclərinin demonik özəlliyi kimi vurğulayır (6, s. 207). Tədqiqatlarda "yeraltı səltənət hakimi, şeytan, cin, iblis" anlamlarında olan Ayna, "kinli, acıqlı ruh" anlamında olan Qaramat, Çor, Azar-Bezar (6, s. 228-232) kimi obrazlardan ətraflı bəhs olunmuşdur. Bir cəhət də diqqəti çəkir. Qeyd olunur ki, xakaslar ayna deyəndə acıqlı ruhları nəzərdə tutmuş, bu, eyni anlayış Tomsk tatarlarının dilində "yek", "cek" sözləri ilə ifadə olunmuşdur (6, s. 228). Məlumdur ki, türkcədə ən çox yayılan və şeytan anlamına gələn söz "yek"dir (12, s. 430). B.Ögel "Yek" (Yel) sözünün qədim türkcədə əsas qarşılıqlarını bu şəkildə göstərir: 1. Külək, 2. Hava, 3. Göy gurultusu, ildırım, 4. Pis ruhlar və cinlər (12, s. 308). Bu yönümdən bədəndəki ağrı və sızıltıya yel deyilməklə bunlar pis ruhlarla əlaqələndirilmişdir (12, s. 309). Onənədə pis ruhlar həm yeraltı, həm də yerüstü ilə əlaqələndirilir. Dunkanlara görə, cinlər pis yerləri, pis əşyaları sevirlər. Ona görə də axşamlar qabları bulaşıq, evi natəmiz saxlamazlar (2, s. 133). Şirvanda inanırlar ki, şər qarışan vaxtı astanada oturmazlar, cinlər, əcinnələr adama toxuna bilər (5, s. 37). Qarabağda deyilir ki, şər vaxtı qoz ağacının altına getməzlər, yeylər adamı vura bilər (4, s. 38). Düşüncədə qaranlıq, axşam, şər vaxtı pis ruhların aktivləşməsi üçün münbit zaman kimi qəbul edilir. Naxçıvanda deyilir ki, cinlər gecələr toy-bayram edərlər (2, s. 20). Eləcə də "kim gecə zoğal ağacının altından keçsə onu cin, şeytan vurar" (2, s. 11). O da səciyyəvidir ki, əyələrlə bağlı mətnlərdə qaranlıq, axşam, şər vaxtı kimi zaman ölçülərinə rast gəlmirik. Әyələr hər kəsdən salam verməyi, hörmət göstərməyi umurlar. Pis ruhlar isə müxtəlif şərtlər daxilində funksiyalarını həyata keçirirlər. Bu şərtlər onların funksiyasının aktivləşməsi və ya bunun əksi ilə əlaqəlidir. Məsələn, cin sözü yerinə üç hərfli adı işlədirlər. Yoxsa orda cinlər peyda olur. Evə girəndə gərək bismillah deyəsən ki, cinlər çıxıb getsinlər (3, s. 35). Göründüyü kimi, söhbət cinlərin peyda olmaması, ya da çıxıb getmələri ilə əlaqəlidir. Bu konteksdə salam və bismillah əyələrə və yeylərə münasibəti işarələndirir, davranışın modelini müəyyənləşdirir. Digər şərtə nəzər salaq: "Cinnər ən çoxu çirhli yerlərdə olullar, ona görə də evi həmişə təmiz saxlamaq lazımdır" (3, s. 35). Bu şərtdə münasibət açıq-aydın ifadə olunub. Yəni cinlərin evə toplanmağını istəmirsənsə, evi təmiz saxla. Yaxud: "Deyəllər, zoğal ağacının altında yatma. Zoğal ağacı şeytan yığıncağıdı. Altında yatsan hər cürə iş baş verər” (3, s. 28). Deməli, düşüncədə cinlərin yaşadıqları və gəldikləri yerlər var. Buna görə də onların gəlməyinin qarşısını almaq lazım olduğu kimi, onlardan qorunmaq da lazımdır. Bunun üçün zoğal ağacının altında yatmamalısan. Bulaşıqlı qabın suyunun, bir də isti suyun yerə atılması da bu sıradandır. "Deyəllər, yeylərə zərər toxunsa, insanı vura bilər" (3, s. 40). Tədqiqat göstərir ki, inanclarda pis ruhlarla münasibətlər təkcə bunlarla məhdudlaşı qalmır. Pis ruhların qarşısına şərt qoyulması, bununla onların qorxudulması fərqli haldır. Naxçıvanda inanırlar ki, evdə nəsə bir şey itəndə onun tapılması üçün piyaləni üzüaşağı çevirmək və demək lazımdır ki, axtardığımı tapmayınca, şeytan, balalarını buraxmayacağam (3, s. 40). Mətnin məntiqindən məlum olur ki, itən bir şeyin tapılması şeytanla əlaqəli düşünülür. Qabı üzüaşağı çevirməklə şeytanın qarşısında şərt qoyulması düşüncənin digər 
tərə̀fini aşkara çıxarır, yəni şeytanın balaları hər yerdə gəzib-dolaşır. Osas isə budur ki, qabı ağzı üstə çevirib o sözləri demək şeytana təsiretmə təşəbbüsüdür. Şeytanın evin bərəkətini aparması, toy eləyəndə cinlərin gəlib evlərdən qazan, düyü, yağ oğurlamaları inanclarda özünəməxsus sistem formalaşdırıb. Naxçıvandan toplanmış bir mətndə oxuyuruq: "Cinnərə bizdən yeylər deyərix. Bizdən yeylər hər yerdə var, ancax insannara görsənməz. Təhcə mal-davar onnarı görər. Ona görə qoyun-keçi olan yerdə bizdən yeylər olmaz, yoxsa ayax altında qalıp qırılallar" (1, s. 37). Cinlərin insana yox, mal-davara görsənməsinin bir çox mətnlərdə ifadəsi ənənədə bu məsələnin ciddi şəkildə mühafizə olunmasını diqqətə çəkir. M.Cəfərli yazır: “... "əуə”" və "bizdən yey” kateqoriyalarına aid olan ruhlar əslində animistik təsəvvürlər əsasında qurulmaqla Yaxşı və Yaman anlayışlarının maddiləşməsini təcəssüm etdirir. Yəni ibtidai düşüncədə heç nə bu düşüncənin obrazlaşdırma sistemindən quraqda qala bilmədiyi kimi, bu etik qoşalıqlar da obrazlaşmışdır” (8, s. 132-133).

Göründüyü kimi, inanclarda obrazların funksiyasının işarələndirilməsi ənənə ilə bağlıdır.

\section{Odəbiyyat}

1. Azərbaycan folkloru antologiyası. Naxçıvan folkloru. I c., Naxçıvan: Әcəmi, 2010, $510 \mathrm{~s}$.

2. Azərbaycan folkloru antologiyası. Naxçıvan folkloru. II c., Naxçıvan: Әcəmi, 2011, 496 s.

3. Azərbaycan folkloru antologiyası. Naxçıvan folkloru. III c., Naxçıvan: Әcəmi, 2012, $560 \mathrm{~s}$.

4. Azərbaycan folkloru antologiyası. Qarabağ folkloru. V c., Bakı: Səda, 2000, $414 \mathrm{~s}$.

5. Azərbaycan folkloru antologiyası. Şirvan folkloru. XI c., Bakı: Səda, 2005, 443 s.

6. Bəydili (Məmmədov) C. Türk mifoloji obrazlar sistemi: struktur və funksiya. Bakı: Mütərcim, 2007, $272 \mathrm{~s}$.

7. Babayev R. Naxçıvan folkloru: bəşərilik, türklük, regionallıq. Bakı: Elm, 2008, 144 s.

8. Cəfərli M. Dastan və mif. Bakı: Elm, 2001, $188 \mathrm{~s}$.

9. Kalafat Y. Altaylardan Anadoluya inanc köçü. Ankara: Berikan Yayınevi, 2012, 244 s.

10. Kalafat Y. Balkanlardan Uluğ Türkistana Türk halk inanclanı. Ankara: Berikan Yayınevi, 2006, $454 \mathrm{~s}$.

11. Мифы народов мира. В 2-х т. Т.2.М.: Советская Энциклопедия, 1988, 719 с.

12. Ögel B. Türk mitolojisi. I c., Ankara: Türk Tarih Kurumu Basımevi, 2002, 644 s.

13. Ögel B. Türk mitolojisi. II c., Ankara: Türk Tarih Kurumu Basımevi, 2003, 610 s.

14. Vəliyev K. Elin yaddaşı, dilin yaddaşı. Bakı: Gənclik, 1987, 280 s. 
Ромелла Али гызы Гюльалиева

Институт права и прав человека НАНА доктор философии по праву, ведущий научный сотрудник romella.gul@mail.ru

\section{КРАТКИЙ АНАЛИЗ РАЗВИТИЯ ЗАКОНОДАТЕЛЬСТВА О ПРЕСТУПЛЕНИЯХ ПРОТИВ ПРАВОСУДИЯ}

Ключевые слова: развитие, краткий анализ, преступления против правосудия

\section{Brief analysis of the development of legislation about crimes against justice Summary}

The article briefly analyses the development of Azerbaijani legislation on crimes against justice. According to the author, the rules on liability for these crimes are gradually gaining the necessary clarity, completeness and accuracy. Obsolete articles are repealed and replaced by new ones that corresponding to the needs and interests of society.

Key words: development, short analysis, crimes against justice

Группа уголовно-правовых норм, способствующих правильному осуществлению правосудия сформировалась в уголовном праве Азербайджана к началу XX столетия. К этому времени нашли свое законодательное закрепление положения, содействующие выявлению истины в судебном процессе, а также принципы обеспечения охраняемых законом интересов различных участников судопроизводства.

Одним из отличительных признаков первого законодательства послереволюционного периода являлось то, что правовые гарантии неприкосновенности чести и достоинства его участников, а также обеспечения безопасности соблюдались не во всех случаях. При осуществлении правосудия судьи руководствовались революционным правосознанием, принимая во внимание такие особенности участника судопроизводства как его социальное происхождение, профессия, образование, воспитание. Зачастую основанием для вынесения обвинительного приговора служило только дворянское происхождение подсудимого при отсутствии необходимых доказательств (8).

В первом УК Азербайджанской ССР, самостоятельная глава о преступлениях против правосудия отсутствовала, а нормы об этих преступлениях располагались в различных главах кодекса. Так, в частности, норма об укрывательстве контрреволюционных преступлений располагалась в первом разделе «О контрреволюционных преступлениях» главы под названием «Государственные преступления». Во втором разделе «О преступлениях против порядка управления» этой же главы УК размещались нормы об ответственности за содействие побегу арестованного либо его освобождение из места заключения или из-под стражи; побег арестованного из места заключения или из-под стражи, совершенный с использованием взлома, подкопа либо повреждения стен, затворов и т.п. (2).

Отдельные разновидности преступлений, нарушающих интересы правосудия, как, например, постановление судьями неправосудного приговора; принуждение при допросе к даче показаний, а также незаконный привод, незаконное задержание предусматривались в главе УК «Должностные преступления».

В главе Уголовного кодекса «Нарушение правил, охраняющих народное здравие, общественную безопасность и публичный порядок» располагалась норма о самовольном оставлении местопребывания, установленного законным распоряжением судебных или административных властей.

Более строгой ответственности подлежали виновные в совершении заведомо ложного доноса и заведомо ложных показаний, которые размещались в разделе «Иные посягательства на личность и ее достоинство» главы УК «Преступления против жизни, свободы и 
досेтоинства личности». К квалифицированным видам этих преступлений относились те же деяния, соединенные с искусственным созданием доказательств обвинения, с корыстными мотивами, с обвинением в тяжком преступлении.

В уголовном законодательстве Азербайджанской ССР 1927 года также отсутствовала специальная глава, посвященная преступлениям против правосудия. Нормы о посягательствах на сферу правосудия в основном содержались в главах «Преступления против порядка управления» и «Должностные (служебные) преступления». К преступлениям против правосудия, в частности, причислялись: оглашение данных предварительного следствия, дознания или ревизионного обследования; разглашение, сообщение, передача должностным лицом сведений, не подлежащих оглашению; незаконное освобождение арестованного из-под стражи или из мест заключения или содействие его побегу; возвращение осужденного в запрещенные для проживания места и другие. В главе «Имущественные преступления» содержалась норма о присвоении чужого имущества, вверенного для определенной цели, или растрате этого имущества (2).

Впервые за всю историю советского периода в уголовное законодательство Азербайджана 1960 года была включена отдельная глава «Преступления против правосудия», в которой предусматривались противоправные деяния данной разновидности не в узком, то есть направленные только против деятельности судов по разрешению уголовных и гражданских дел, а в широком понимании правосудия. Таким образом к единому объекту уголовно-правовой охраны была сведена деятельность не только судов, но и других органов и лиц, содействующих им установлению истины по делу, способствующих принятию и исполнению законного и обоснованного судебного решения (2).

В своей первоначальной редакции УК АР 1960 года содержал 15 статей об ответственности за преступления против правосудия, совершаемых не только должностными лицами, противодействующими законному осуществлению правосудия, но и преступления других субъектов. Первую группу посягательств составляли, в частности, деяния, совершаемые должностными лицами органов правосудия. Во вторую группу преступлений входили общественно опасные деяния, совершаемые работниками иных органов, должностными и частными лицами, например, побег из мест лишения свободы, предварительного заключения или из-под стражи; понуждение свидетеля или потерпевшего к даче ложных показаний или эксперта к даче ложного заключения либо подкуп этих лиц и др. (2).

Данная систематизация преступлений против правосудия позволяющая выделить общественно опасные деяния, совершаемые путем злоупотребления или превышения должностных полномочий при реализации целей правосудия его непосредственными представителями, и посягательства, совершаемые иными лицами, содействовала тому, что в течение многих десятилетий определяющим являлось мнение о необходимости систематизации преступлений против правосудия на основании субъекта преступления (8).

Реформа законодательства, начавшаяся в конце 80-х - начале 90-х гг. прошлого столетия, практическое осуществление принципа разделения властей, настоятельная необходимость обеспечения незыблемости и самостоятельности судебной власти, вызывали потребность в использовании для защиты осуществляющих правосудие представителей судебной власти специальных уголовно-правовых средств.

Принятым 2 ноября 1989 года Законом СССР «Об ответственности за неуважение к суду» уголовной ответственности подлежали виновные в совершении отдельных посягательств против судей, народных или присяжных заседателей. Указом Президиума Верховного Совета АзССР от 11 декабря 1998 года УК АзССР был дополнен статьями об ответственности за оскорбление судьи, народного или присяжного заседателя; вмешательство в разрешение судебных дел; угрозу по отношению к судье, народному или присяжному заседателю (5). 
-Нормы главы о преступлениях против правосудия в последующие годы неоднократно подвергались различным изменениям. Изменения и дополнения в основном были направлены на обеспечение лиц, осуществляющих правосудие, необходимой защиты (4). Помимо этого, на уголовном законодательстве в общем и нормах данной главы, в частности, сказались изменения, произошедшие в различных сферах жизнедеятельности общества и государства - политических, идеологических и социально-экономических отношениях. Так, в частности, в связи с исключением из системы наказаний ссылки и высылки, была декриминализирована норма о самовольном возвращении высланного в места, запрещенные для проживания.

В Модельном Уголовном кодексе для государств - участников СНГ от 17 февраля 1996 года была предусмотрена самостоятельная глава 34 об ответственности за преступления против правосудия, состоявшая из норм, предусмотренных законодательством большинства бывших республик Советского государства. Начиналась данная глава со ст. 324, об ответственности за вмешательство в разрешение судебных дел и производство предварительного расследования. Вслед за ней располагались нормы о заведомо ложном доносе (ст. 325); несообщении о преступлении или его укрывательстве (ст. 326); воспрепятствовании явке свидетеля, потерпевшего или даче ими показаний (ст. 328); лжесвидетельстве (ст. 329) и др. (7).

Ответственность в Модельном уголовном кодексе предусматривалась и за преступления, субъектами которых выступали сами представители власти, осуществляющие правосудие. Так, в частности в статье 337 говорилось о привлечении заведомо невиновного лица к уголовной ответственности; статья 332 предусматривала ответственность за принуждение к даче показаний лицом, производящим предварительное следствие или осуществляющим правосудие и др. В завершении данной главы в статье 341 говорилось об ответственности за побег из мест лишения свободы или из-под стражи (7).

В связи с тем, что включение в число преступлений деяния в виде несообщения о достоверно известном готовящемся или совершенном особо тяжком преступлении (ч. 1 ст. 326 Модельного УК) многими учеными воспринималось как препятствие для обеспечения демократических прав и свобод личности Уголовные кодексы ряда государств СНГ не предусмотрели ответственности за недонесение о преступлении. Однако, в целях предупреждения, быстрейшего раскрытия и разоблачения уже совершенного преступления указанная норма содействует правоохранительным органам в их деятельности по реализации отдельных целей правосудия. Исходя из этого УК Азербайджана предусмотрел ответственность за недонесение и укрывательство преступлений в ст.307 (10). Помимо УК Азербайджана, в УК Республики Беларусь (ст. 406 УК), Республики Узбекистан (ст. 241 УК) также установлена уголовная ответственность за указанное преступление $(12,13)$.

После принятия в 1999 году нового УК Азербайджана были внесены отдельные дополнения и изменения в главу о преступлениях против правосудия. Так, в частности, статья 293 о принуждении к даче показаний в соответствии с Законом АР от 29 июня 2012 года «О внесении изменений и дополнений в Уголовный кодекс Азербайджанской Республики» изложена в новой редакции и называется пытка, не считающееся пыткой жестокое, бесчеловечное или унижающее достоинство обращение или наказание (1, с.478).

В статье 301 УК АР об ответственности за разглашение сведений о мерах безопасности, применяемых в отношении работников суда и правоохранительных органов из числа потерпевших были изъяты присяжные заседатели, судебные надзиратели и судебные исполнители, а диспозиция статьи 304 УК АР, которая ранее определялась как «побег из места лишения свободы или заключения, либо из-под стражи, совершенный заключенным под стражу или задержанным лицом» ныне изложена в следующей редакции: «побег из места лишения свободы или заключения, либо из-под стражи, совершенный лицом, отбывающим наказание, заключенным под стражу или задержанным лицом». Существенным образом претерпели изменения санкции за преступления против правосудия (10). 
Наиболее значительным изменениям подверглась статьи 286 и 293 УК Азербайджана, предусматривающие ответственность за воспрепятствование осуществлению правосудия и производству предварительного расследования и применение пытки.

Ст.125 Конституции Азербайджана провозглашает принцип независимости правосудия от каких-либо вмешательств извне (6). Об этом же говорится в ст.6 Европейской Конвенции от 4 ноября 1920 года «О защите прав и основных свобод человека». Статья 286 предусматривает два вида вмешательства - 1) вмешательство в деятельность суда в целях воспрепятствования осуществлению правосудия и 2) вмешательство в деятельность прокурора, следователя или лица, производящего дознание в целях воспрепятствования объективному, полному и всестороннему расследованию дела. При этом закон не определяет способы вмешательства определяя их «в какой бы то ни было форме» (3). Следовательно, способы вмешательства могут быть самыми разными: требования, давление, обещания оказать услуги, угрозы причинить неприятности, ущемить или иным образом нарушить законные права и интересы. При этом имеются в виду не процессуальные меры воздействия, поскольку процессуальными мерами признаются правомерные способы обращения с ходатайствами, жалобами, протестами, т.е. разрешенные процессуальным законодательством. Кроме того, не признается незаконным вмешательством критика действий работников правоохранительных органов или вынесенных ими решений в средствах массовой информации. В случае подкупа работников правосудия, виновный должен привлекаться к ответственности по совокупности статей - 286 и 312 УК АР, если же эти действия были сопряжены с применением или угрозой применения насилия, то по совокупности со ст. 288 УК АР.

Статья 293 УК АР предусматривавшая ранее ответственность за принуждение к даче показаний, ныне именуется как пытка, не считающееся пыткой жестокое, бесчеловечное или унижающее достоинство обращение или наказание. Указанное изменение было внесено в УК AP Законом Милли Меджлиса № 405 - IVQD от 29 июня 2012 года (4). «Выбивание» показаний насильственными методами характерно для всех карательных систем от древних времен, средневековой инквизиции, советских политических процессов 30-50-х годов и до настоящего времени. Подобные методы применяются в большинстве случаев из карьеристских побуждений, стремления показать себя профессионалом, умеющим раскрывать любые преступления и по иным мотивам. Главное состоит в том, чтобы не допустить, когда одно преступление раскрывается и наказывается путем совершения другого преступления, причем совершается это людьми, по долгу службы обязанными бороться с преступностью.

Определение пытки содержится в примечании к этой статье, а понятие жестокого, бесчеловечного или унижающего достоинство обращения или наказания выработано судебно-следственной практикой и теорией уголовного права. В то же время, полагаем возможным Пленуму Верховного Суда в постановлении, посвященном преступлениям против правосудия, дать разъяснение по вопросу о понятии жестокого и бесчеловечного обращения по ст.293.1 и его соотношения с понятием «пытки» по ст. 293.2. УК Азербайджана.

Полагаем, что к жестокому обращению следует относить наряду с некоторыми другими такие средства воздействия на подозреваемого и обвиняемого как использование гипноза, дача наркотических, токсических и одурманивающих веществ, в том числе алкоголя, незаконное лишение свободы, применение побоев и угроз вплоть до причинения легкого вреда здоровью. В случае причинения тяжкого или менее тяжкого вреда здоровью потерпевшего содеянное должно квалифицироваться по ст. 293.3. УК АР и наказываться лишением свободы на срок от шести до одиннадцати лет. 


\section{Литература}

1. Azərbaycan Respblikasının Cinayət Məcəlləsi. Maddələr üzrə normativ mənbələrə istinadla. Bak1. "Digesta" nəşriyyatı. 2017. C. 478.

2. Cinayət qanunları külliyyatı. 1920-2000. Almanax. Bakı. Hüquq Yayın Evi. 2014.

3. Европейская Конвенция от 4 ноября 1920 года «О защите прав и основных свобод человека» [Электронный ресурс] / Режим доступа https://pandia.ru/text/78/242/ 14698.php

4. Закон Милли Меджлиса № 405 - IVQD от 29 июня 2012 года [Электронный ресурс]. Режим доступа: http://base.spinform.ru/show_doc. fwx?rgn $=54073$

5. Закон Азербайджанской Республики «О государственной защите работников судебных и правоохранительных органов» от 11 декабря 1998 года № 586-IQ [Электронный ресурс]. Режим доступа: $\mathrm{http}: / /$ base.spinform.ru/show_doc.fwx?rgn=2741

6. Конституция Азербайджанской Республики. Bakı. "Digesta" nəşriyyatı. 2017.

7. Модельный уголовный кодекс для стран СНГ. [Электронный ресурс]. Режим доступа: https://docs.cntd.ru/document/901781490

8. Уголовное право России. Части Общая и Особенная. М.: Проспект. 2017.

9. Указ Президента Азербайджанской Республики об углублении реформ в судебноправовой системе от 3 апреля 2019 года [Электронный ресурс]. Режим доступа: https://ru.president. az/articles/32587

10. Уголовный кодекс Азербайджанской Республики. Баку. Издательство «Hüquq Yayın Evi”. 2018.

11. Уголовный кодекс Российской Федерации. [Электронный ресурс]._Режим доступа: http:// $\underline{\text { ukodeksrf.ru/ }}$

12. Уголовный кодекс Республики Беларусь [Электронный ресурс]. Режим доступа: http://pravo. kulichki.com/vip/uk/

13. Уголовный кодекс Республики Узбекистан [Электронный ресурс]. Режим доступа: http://fmc. uz/legisl.php?id=k_ug 


\title{
DİSTANT TOHSIL TOHSILIN SÜROTLO İNKIŞAF EDON FORMALARINDAN BİRİ KIMI
}

\author{
Açar sözlor: tahsil, distant, tadris, elektron, internet
}

\section{Distant education as one of the fastest growing forms of education Summary}

Since march 2019 due to the rapid spread of the COVID -19 epidemic in Azerbaijan, as well as in the whole world, there was no break in education. Although we had a lot of problems at the beginning, education continued in both higher and secondary schools of our country. The pandemic activated this backward and underdeveloped type of education and showed us its advantages and disadvantages.

Key words: education, distant, teaching, electron, internet

Son zamanlarda pandemya səbəbindən tədrisin məsafəli, yaxud da distant formada keşirilməsi təhsil işçilərinin yükünü və məsuliyyətini bir neçə dəfə artırıb desək yanılmarıq. Distant təhsilə tam hazır olmasaq da, bir sıra çətinliklərə baxmayaraq günün tələbinə uyğun olmağa çalışaraq bu çətinliyin öhdəsindən mümkün qədər yaxşı gəlməyə çalışırıq. Lakin xüsusi qeyd etmək lazımdır ki, distant təhsil yalniz Azərbaycanda deyil, bütün dünyada böyük sürətlə inkişaf edir. Bəllidir ki, yeni başlanan işin də özünə məxsus çətinlikləri, problemləri vardır.Buna keçməmişdən əvvəl distant təhsil nədir və hansı formaları olduğunu dəqiqləşdırib sonra digər sualları müzakirə edək .

“ Distant təhsil - tədris prosesinin elektron, telekommunikasiya, proqram-texniki vasitələr əsasında təşkil olunduğu formasıdır. Distant təhsil öyrədən və öyrənən arasında əlaqəni telekommunikasiya və kompüter şəbəkələri vasitəsi ilə operativ, müntəzəm dialoq, əks əlaqə əsasında, uzaq məsafədən həyata keçirir." [2]

Distant təhsil tədris edilən zaman informasiya öyrəncilərə daha çox elektron dərs vəsaitlərindən istifadə etmək yolu ilə tədris olunur. Bu məqsədlə daha çox elektron tədris materialları, elektron kitablar, teledərslər və s. formalardan istifadə edilir. Distant təhsil özü ilə bərabər bir çox yeni xüsusiyyətlər də gətirdi. Həmin xüsusiyyətlərə distant təhsilin tədrisi üçün müxtəlif tədris proqramlarının istifadəsi, tədris prosesində müəllimin yeni rolu ( müasir elektron və kompüter vasitələrindən istifadə bacarıqlarına malik olaraq onlardan istifadə edib tədrisi təşkil etmək), təhsilin keyfiyyətinə xüsusi nəzarət, təlim zamanı xüsusi vasitə və texnologiyalarından istifadə olunması və digərləri aiddir.

Danılmaz faktdır ki, bizim ölkəmizdə distant təhsilin tam yayılma səbəi COVID -19 pandemiyasının yayılmasının qarşısınınn alınması məqsədini daşıyır. Lakin uzun illərdir ki, Türkiyə, Avropa və Amerika universitetlərinin xüsusi distant təhsil şöbələri fəaliyyət göstərirdi.Tədqiqatçılar distanat təhsilin ilk yaranma tarixinin 1840 -cı illərə təsadüf etdiyini də qeyd edirlər." Distant təhsil formasını yaratmaq cəhdi 1840-cı ildə baş verib. İsak Pitman poçt məktubları vasitəsilə Birləşmiş Krallıqda tələbələrə stenoqrafiyanı öyrətməyə başlamışdı." [3]

Azərbaycanda isə distant təhsilin yaranma tarixi çox da uzaqlara gedib çıxmır.Çünki distant təhsilin rəsmi yaranmasını 19 iyun 2009 -cu il hesab etmək olar. Belə ki, "Təhsil haqqında " qanunun təsdiq etdiyi 13-cü maddəsinə əsasən respublikamıda əyani, qiyabi və distant təhsil forması yanaşı təhsil formaları kimi qəbul olunub.

Distant təhsil haqqında qərar qəbul edilsə də ,Azərbaycanda onun tətbiqi çox yubandı desək yanılmarıq. Qanunun qəbulundan xeyli keçsədə, demək olar ki, çox az sayda universitetlər təhsilin bu növündə tələbələrin təhsil alması üçün şərait yaradılmasında ilk addımlarını atsalar da, orta məktəb və liseylərdə bu məsələ toxunulmamış qalırdı. 
Distant və ya məsafəli təhsili necə almaq olar və ya təhsilin hansı növləri ilə oxumaq olar sualına isə belə cavab vermək olar. Arzu edən hər bir şəxs distant təhsil vasitəsi ilə ali təhsil ; magistr təhsili, ikinci ali təhsil ala bilər və eyni zamanda arzusunda olduğu xarici dili öyrənə bilər, MBA və ixtisasartırma proqramları üzrə müxtəlif kurslarda iştirak edə bilər ; və orta təhsil ala bilər. Oslində bu tələbə və şagirdlərə ixtisas və savadlarını artırmaq üçün çox gözəl imkanlar yaradır. Tələbə həm qənaətli, həm sürətli və heç bie yerə getmədən, ölkəni tərk etmədən təhsilini davam etdirə bilər və bu da dəfələflə ucuz başa gələr.

Son illərdə təhsilin ən sürətlə inkişaf edən formalarından biri distant təhsildir. İnternetin və komputer proqramlarının verdiyi saysız imkanlar təhsil almaq və ya ixtisasını artırmaq istəyənlər üçün çox gözəl imkanlar yaradır ki , bu da öz növbəsində taza kompüter proqramlarının həm yaranmasına, həm də istifadəsinə çox böyük tələbat yaradır. Nəticədə distant təhsilin inkişaf dinamikası artır və ondan istifadə sayı nəzərə çarpacaq dərəcəədə yüksəlir ki, bu da təhsil sahəsində geniş bazarın yaranmasına və təhsil müəssisələri araslındakı rəqabətin güclənməsinə aparır .

Maraqlı araşdırmalar aparılmış və aparılan tədqiqatlara əsasən məlum olmuşdur ki , distant təhsil vasitəsi ilə təhsilini artırmaq ya da davam etdirmək istəyən "tələbələrin" əksəriyyəti yaş1 25dən yuxarı olanlar, maddi və ya başqa səbəbdən işindən ayrılmaq istəməyən, amma işlədiyi sahədə ixtisasını artırmaq istəyən şəxslərdir. Eyni zamanda distant təhsil ödəniş, vaxt və digər şərtlər baxımından hər kəs üçün uyğundur. Sözsüz ki, ənənəvi təhsil kimi distant təhsilin də müsbət və mənfi cəhətləri vardır.

a)Distant təhsil proqramları ucuz başa gəldiyinə görə, təhsil müəssisəsinin əlavə texnikaya və avadanlığa ( sinif otaqlarına, lövhə, kompüter, multimediya və s) ehtiyacı qalmır.

b)Şagirdlərin müstəqil işləmələri üçün çox vaxt ayrılır ki, bu da müəllimlərə gün ərzində daha çox tələbə ilə məşğul olmağa şərait yaradır.

c)Distant təhsil internet üzərindən həyata keçirildiyi üçün internetin olduğu hər yerdə və hər kəs üçün uyğundur, həm şəhər, həm də internetin olduğu ucqar kənd yerlərində hamı üçün əlçatandır

d)Distant təhsil auditoriyada kompleks keçirən həm də psixoloji cəhətdən zaif olan və ünsiyyətdə çətinlik çəkən tələbələr üçün ideal variantdır.

e) Distant təhsil ənənəvi təhsildən fərqli olaraq mobildir.

Distant təhsil vaxtını boş keçirmək isməyən, evinə -ailəsinə daha çox vaxt ayıran insanlar üçün ən uyğun variantdır. "Hər hansı şəxs işini itirmək qorxusu olmadan və işdən ayrılmadan ixtisasını artırmaq və ya yeni biliklər əldə etmək imkanı əldə edir.[5]

Bütün sadaladıqlarımızla birlikdə xüsusi olaraq vurğulamaq lazımdır ki, distant təhsil həm ali, həm də orta ixtisas məktəblərinə tələbə sayını artırmağa, cüzi xərclə xeyli sayda tələbəyə ali və orta təhsil almaq üçün imkan yaratmağa, başqa ölkələrdən kifayət qədər tələbə və müəllimi bu işə cəlb etməyə hədsiz gözəl imkanlar yaradır. $\mathrm{Bu}$ isə özlüyündə təhsil ocaqlarının maddi bazasının artmasına,işçilərin əmək haqqının əhəmiyyətli dərəcədə artırmasına gətirib çıxaracaq.

Bu sadaladığımız müsbət cəhətlərlə yanaşı distant təhsilin aşağıdakı mənfi cəhətləri də vardır :

Dərs prosesində tələbələrin fərdi fərqlərini görmək çətinləşir; keçilən dərslərin interaktivliyi kifayət qədər olmur; internet baxımından fasilələr olur ki, bu da dərsin gedişatına ciddi zərər vurur; öyrədənlə öyrənən və ya öyrənənlər arasında canlı təmasın olmaması özü də problem yaradır;distant təhsil almış tələbənin diplomu keyfiyyət baxımından normal qəbul edilmir və s.

Bütütn bunlarla yanaşı, hələ də mövcud olan bir sıra çatışmazlıqlar təhsil sistemimizin bu tip hallara hələ hazır olmadığını göstərdi. Gələcəkdə bu cür hallarla üzləşməmək üçün bir sıra qabaqlayıcı tədbirlər görülməli, distant təhsilin daha əlçatan və sadə mexanizmi hazırlanmalı və yeniliklərlə bağlı treyninqlər, seminarlar və təlimlər keçirilməlidir.

Bildiyimiz kimi koronavirus pandemiyasının yayılması nəticəsində indiyə kimi ölkələrin əksəriyyətində arxa planda olan distant təhsil ön plana keçərək daha sürətlə inkişaf etməyə başladı və təhsil sahəsindəki boşluğu doldurmaq üçün bundan uyğun başqa variantın olmaması bir daha gündəmə gəldi. Bizim ölkəmizdə də bu sahədə təcili və təxirəsalınmaz həyata keçirilməyə başladı.Respublikamızda müxtəlif platformalarda təhsilin davam etdirilməsi ilk əvvvəl müsbət 
qarşılanmasa da, zaman keçdikcə xəstəliyin sürətlə yayılması və tələfatlar ən yaxşı yolun distant təhsil olduğunu dərk edərək hətta bəzi valideyinlər distant təhsilə uüstünlük verərək övladlarını məktəbə ənənəvi dərs üçün göndərməkdən imtina etdilər. Azərbaycan da yerləşən bütün ali və orta ixtisas məktəblərində təhsil "Microsoft Teams"və ya "Zoom"platformasının tətbiqi ilə fəaliyyətlərini davam etdirsələr də, hələ də problem olaraq qalan məsələlər vardır.Yüksək tezlikli internetin hamı üçün əlçatan olmaması, tələbə və müəllimlərin IKT sahəsində bilik və bacarıqlarının kifayət qədər olmaması, elektron dərsliklərin kifayət qədər olmaması və sairə kimi problemlər hələ də aktual olaraq qalır. Distant təhsil zamanı dərsin maraqlı və tələbələr tərəfindən normal başa düşülməsi özü də müəllim və tələbələr üçün ilk vaxtlarda çox böyük problem idi.Uzun illər normal təhsilə alışmış müəllim və şagirdlər ilk vaxtlarda bu kimi çətinliklərlə çox qarşılaşsalar da zamana keçdikcə alışmağa və dərsin mərhələlərini düzgün təyin edib şagirdlərin marağını geri gazanmağı bacardılar.Pandemiya dövründə təhsil işçilərinin bu sahədə rolu danılmazdır məncə. Bu sahədə qalan problərin bəzilərinin həlli qisa müddət öz həllini tapa bilən məsələlərdir.Vaxtaşırı İKT ilə bağlı onlayn treyninq və seminarların keçirilməsi və bu kimi tədbirlər məsələnin bu hissəsinin həllinə çox böyük kömək edə bilər.Bu da öz növbəsində distant təhsil zamanı yeni metod və yanaşmaların öyrənilməsi və tətbiqi üçün geniş imkanlar açar.

Düşünürəm ki, distant təhsil sahəsində zəngin təcrübəsi olan aparıc1 universitetlərin təcrübəsindən faydalanmaq çox vacibdir. Bu baxımdan həm respublikamızdakı ali və orta ixtisasa məktəblərinin, həm də xarici ölkələrin bəzi təcrübəsindən yararlanmağın faydası daha çoxdur.Bunları nəzərə alaraq yaxın zamanlarda qonşu ölkələrin təcrübəsindən yararlanaraq distant təhsilin inkişafına böyük töhfələr vermək olar.

\section{Odəbiyyat}

1. https://www.celt.az/distant-t\%C9\%99hsil-n\%C9\%99dir-az\%C9\%99rbaycanda-distantt\%C9\%99hsil-sistemi/

2. https://az.wikipedia.org/wiki/Distant_t\%C9\%99hsil

3. https://muallim.edu.az/news.php?id=10913

4. https://www.almazhasret.com/?p=3575

5. https://aztehsil.com/news/10206-distant-tehsil-ve-xususiyyetleri.html

6. https://stm.az/publications/meqaleler/koronavirus-pandemiyasnn-zerurete-cevirdiyi-distanttehsilin-ustunlukleri-ve-catmazlar 
Fəhminə Әsgər q1zı İsmayılova

AMEA Nosimi adına Dilçilik İnstitutu

doktorant

fehmineismayilova@gmail.com

\title{
XəBӘRLİK KATEQORIYYASININ LINNQVISTIKK VӘ SOSİOLINQVISTİK ASPEKTLəRİ
}

\author{
Açar sözlor: sosiolinqvistika, sintaksis, xəbərlik, dialekt, differensiallaşma, cəhət, linqvistika
}

\section{Linguistic and sociolinguistic aspects of the category of predicative Summary}

The problem of the relationship between sociolinguistics and syntax is addressed in this article. The syntax of dialects is a less developed area than morphology and phonetics. The main reason for this is the lack of basic syntactic features that distinguish dialects. The sentence, which is one of the main sections of the syntax and one of its most important elements, is a general feature of the work in which the predicate or predicative category used in dialects in different regions of Azerbaijan.

Key words: sociolinguistics, syntax, predicative, dialect, differentiation, aspect, linguistics

\section{Giriş}

Sosialinqvistika ilə Linqvistika fərqli terminlərdir. Linqvistika dilin quruluşu haqqında elm olduğu halda, sosialinqvistika həmin quruluşdan istifadə edərək necə ünsiyyət qurulması haqqında elmdir. Dell Hymes dilin öyrənilməsində funksional və struktural yanaşmalar arasındakı fərqə diqqəti çəkmişdir. Struktur yanaşma dilin (kodun) quruluşuna diqqəo yetirir və kodun təhlilinə birinci dərəcəli əhəmiyyət verilir. Digər tərəfdən, funksional yanaşma dilin funksional tərəfinə, yəni cəmiyyətdə istifadəsinə yönəlmiş̧ir. Dildən istifadənin təhlilinə birinci dərəcəli əhəmiyyət verilir və kodun təhlili ikinci dərəcəlidir. Dilçi dili kontekstdən kənarda analiz edir, sosiolinqvist isə dili sosial kontekstdə istifadə edildiyi kimi təhlil edir. Qısaca deyə bilərik ki, dilçilik dilin, ilk növbədə dilin quruluşunun öyrənilməsidir. Sosiolinqvistika, dilin fərqli məqsəd və funksiyalar üçün fəqrli səviyyələrdə öyrənilməsidir. Sosiolinqvistika dedikdə, iki termin - "sosio" və ya "cəmiyyətə aid", "lingua" və ya "dilçiliyə aid" terminləri diqqətimizi çəkir. Sosiolinqvistika dilçiliyin bir qolu olub, dilin cəmiyyətlə əlaqəsini öyrənən elmdir. Dil və cəmiyyət bir-birilə six əlaqədədir. Cəmiyyət olmadan dil mövcud ola bilməz. Sosiolinqvistika həm dilin, həm də cəmiyyətin təbiəti məsələlərini araşdırır. Biz müxtəlif sosial kontekstlərdə müxtəlif üslublarda danışırıq. Sosialinqvistika dil və onun istifadə olunduğu məzmunla əlaqədardır. Sosiolinqvistika dilin sosial funksiyasını və mənanın çatdırılması üsulunu araşdırır. Sosialinqvistika müxtəlif kontekstlərdə niyə fərqli şəkildə danışıldığını izah edir.

Fişmana görə sosialinqvistika "kimin hansı dili nə vaxt və kimə" danışdığı məsələlərini tədqiq edir. Fişmana görə sosialinqvistikanın problemləri aşağıdakılardır: (3, s.4).

a) Danışanın kimliyi və onun cəmiyyətdəki rolu

b) Onun istifadə etdiyi dil

c) Dinləyicinin kimliyi

d) İnsanlar danışarkən mövcud vəziyyət

Cəmiyyət müxtəlif quruluşa malik olduğu üçün dildə təbəqələşmə meydana çıxır. Təbəqələşmə isə müəyyən sosial qrup arasındakı dil və danışıq fərqlərində öz əksini tapır. Bununla da sosiolinqvistik göstəricilər meydana çıxır. Sosiolinqvizmin əsas tədqiqat metodlarından biri sosial və dil hadisələrinin korrelyasiyasıdır, yəni statistik asılılığı.

$\mathrm{Bu}$ qeyd etdiyimiz cəhətlər dilin sintaktik sistemində də özünü qabarıq şəkildə biruzə verir. Dilin sosial-ərazi, sosial-sinfi, sosial-peşə differensiallaşması sintaktik əlaqələrdə öz əksini tapır. Sosial münasibətlərə əsaslanan dil müxtəlif funksiyaları yerinə yetirir. Beləliklə dildə differensiallaşma prosesi baş verir. Dilin differensiallaşması prosesi sosiolinqvistikanın tədqiqat obyektlərindən biridir. A.A.Potebnya qeyd edir ki, dilin inkişafının müxtəlif tarixi dövrlərində 
cüm̀ləyə müxtəlif təriflər verilmişdir, ancaq ən əsası isə cümlənin sosiolinqvistik və struktur cəhətdən araşdırılmasıdır. (1, s. 343). Cümlənin yaranmasında ən böyük rolu oynayan ünsürlərdən biri xəbərdir. Cümlənin özəyini təşkil edən bu termin sosiolinqvistik aspektdən təhlil edildikdə müxtəlif maraqlı məqamlar meydana çıxır.

\section{Anasının qollarında sevimli oğlu can verdi. \\ Ela bil yă̆lş susuz torpaqlara can verdi.}

$\mathrm{Bu}$ cümlələrdə xəbərin ifadə olunduğu iki eyni frazada dilin differensiallaşması prosesi baş vermişdir. Birinci cümlədə xəbərin ifadə olunduğu "can vermək (ölmək)" frazası öz həqiqi mənasını saxlamış, həmin frazaya məxsus ilkin sosial münasibəti özündə əks etdirmişdir. İkinci cümlədə eyni fraza ilə ifadə olunan "can vermək (diriltmək)" mücərrəd mənada işlənərək predikat və subyekt arasındakı törəmə sosial münasibətləri əks etdirir.

Bu differensiallaşma dil ideoloji funksiyasını yerinə yetirərkən də özünü aydın şəkildə biruzə verir. Obülfəz Rəcəbli qeyd edir ki, dilin ideoloji differensiallaşması dilin ideoloji funksiyasına əsaslanır. İdeoloji funksiya istər bütövlükdə, istərsə də onun ayr1-ayrı ünsürlərində ifadə oluna bildiyi üçün ayrı-ayrı dil ünsürlərinin məfkurəviləşdirilməsi, məfkurəvilikdən azad edilməsi, ideolo ji baxımdan neytrallaşdırılması, törəmə məfkurəviləşdirilməsi prosesləri geniş sosiolonqvistik maraq doğurur. İki məfkurəni qarş1-qarşıya qoyduqda həmin dildə onların ifadəsinin dil vasitələri sistemi səciyyəli müəyyən sosiallaşmış münasibətlər əmələ gətirir. Allah qoysa,Allah kərimdir, Səni Allaha tapşırıram, Allah rohmlidir, Allah adildir, Allah ovozini versin, Allah rohm elosin, Allah rəhmət elosin, Allah o dünyasını versin, Allah hər şeyi görür vo s. (1, s.374) bu kimi cümlələrə nəzər yetirsək, aydın olar ki, cəmiyyətin konkret dini inanc1 olan təbəqəsinə xitab edir. Qeyd etdiyimiz kimi dilin ifadə olunmasında ən böyük rolu cümlə oynayır cümlənin özəyini isə xəbər təşkil edir. Bu cümlələrdəki hökmü də xəbər yerinə yetirir və bu hökm vasitəsilə müəyyən bir sosial bir fikir cəmiyyətə ötürülür. Səni Allaha tapşırıram cümləsindəki "Allaha tapşırmaq" ifadəsi iki mənada- həm mənfi, həm də müsbət mənada işlədilir. Bu zaman danışanın mövcud vəziyyətindən aydınlaşdırmaq olar ki, bu hökm hansı mənada istifadə edilmişdir. Müsbət mənada işlədilən hökm birini Allaha əmanət etmək, mənfi mənada işlədilən hökm isə birini Allaha həvalə etmək mənasını verir.

Sosiolinqvistikanın tədqiqat obyektlərindən biri də dilin sosial differensiallaşması prosesidir. Sosial differensiallaşma dedikdə sosial, sinfi dialektlər, aristokratiyanın dili, fəhlələrin dili, kəndlilərin dili və.s başa düşülür. Dildə bu cür fərqlilik ən qədim zamanlardan başlamışdır. Dilin dialekt və şivələri zaman keçdikcə artıq milli dil şəklində təmərküzləşməyə başlamışdır.

Azərbaycan dilinin sosial differensiallaşması problemi xəbərlik kateqoriyasının ifadə olunmasında öz rəngarəngliyi ilə seçilir. Xəbərlik kateqoriyasının dialekt və şivələrlə ifadəsi burada xüsusi yer tutur. Cümlədə xəbərliyi ifadə etmək üçün isim, sifət, say, əvəzlik və feil müəyyən elementlər (şəkilçilər) qəbul edirlər. Həmin şəkilçilərin mənşəyi araşdırılmışdır və aydın olmuşdur ki, birinci şəxs tək və ikinci şəxs tək və cəminin şəkilçiləri öz mənşəyinin əvəzliklərdən, -dır, -dir, dur, -dür şəkilçiləri isə öz mənşəyini durur feilindən götürmüşdür. Birinci şəxs cəminin xəbərlik şəkilçiləri isə hələ də mənşəcə aydınlaşdırılmamışdır. İndiki zamanda xəbərlik kateqoriyasını düzəltmək üçün bütün dialekt və şivələrdə 1-ci və 2-ci şəxs təki üçün -am, -əm, -san, -sən şəkilçisi işlədilmişdir. Bakı, Quba və Lənkəran dialektlərində isə bu -yam, -yəm kimi işlənir.

Şəkilçilərin işlənməsinə görə dialekt və şivələr bir neçə qrupa bölünürlər:

> Birinci qrupa dördvariantlı şəkilçilər; Qazax, Qarabağ, Gəncə, Naxçıvan qrupu daxildir.

$>$ İkinci qrupa ikivariantlı şəkilçilər; Şamaxı, İsmayıllı dialektləri daxildir

$>$ Üçüncü qrup dialektləri isə digər qruplardan fərqli olaraq qoşulduğu sözün ahənginə tabe olmayaraq bir cür ifadə olunur (-1x,-ik, -uğ, -ux); bu qrupa Şəki, Orduabad, Təbriz, Zaqatala və Qax qrupları daxildir.

İknici şəxs cəminin işlənməsinə görə də dialekt və şivələr bir neçə qrupa bölünür:

$>$ Ahəng qanuna tabe olaraq Gəncə, Qazax, Qarabağ dialektlərinə daxil olan dördvariantlı şəkilçilər (-sınız, -siniz, -sunuz, -sünüz) 
İkinci qrup dialektlərini ikivariantli olan -suz, -süz şəkilçiləri təşkil edir. Bu şəkilçilərə Naxçıvan və İrəvan dialektlərində daha çox rast gəlinir

Üçüncü qrupu isə yenə də ahəng qanununa tabe olmayan bir variantlı şəkilçi (-1z, -uz,-az, sluz) təşkil edir.

Bəzən isə 3-cü şəxs təkdə işlənmiş xəbərlik şəkilçilərinin son samiti düşür, -dı, -di,-du,-dü kimi tələffüz olunur.

Keçmiş zamanda xəbərliyi ifadə etmək üçün “idi” köməkçi sözündən istifadə olunur. Bu zaman sonu samitlə bitən sözlərdə onun ilk saiti düşür (gəlmişdi), sonu saitlə bitən sözlərdə isə saitlə hissəcik arasına " $y$ " samiti əlavə edilir (alaydı).

-Dım, -dim, -dum, -düm şəkilçisi bütün dialekt qruplarında keçmiş zaman xəbərlik şəkilçisi kimi işlənir.

Keçmiş zamanda xəbərlik kateqoriyasının birinci şəxs cəminin işlədilməsinə görə dialektlər 3 qrupa bölünür:

* Qazax, Qarabağ və Gəncə qrupuna daxil olan dördvariantlı şəkilçilər: -dıx, -dix', -dik, -dux, -düx', -dük

* İkinci qrupa ikivariantlı şəkilçilər: -dıx, -dıx', -dig, -duğ, -düg

* Üçüncü qrupu isə yenə də ahəng qanununa tabe olmayan birvariantlı şəkilçilər daxildir: -duğ, -dix, -dox/dux

Keçmiş zamanda ikinci şəxs tək və cəm şəkilçilərinin işlədilməsinə görə dialekt və şivələrin üç qrupu var.

1.Qazax, Qarabağ, Gəncə qrupu: -dın, -din, -dun, -dün, -dınız,-diniz, -dunuz, -dünüz

2.Bakı, Quba, Şamaxı, Muğan, İsmayıllı, Naxçıvan, İrəvan qrupu: -dun, -dün, -duz, -düz; -dın, -din, -diz, -diz

3.Şəki, Naxçıvan, Orduabad, Təbriz, Zaqatala-Qax qrupları: -dız, -döz, -düz, -dıız

Keçmiş zamanda xəbərlik şəkilçilərinin üçüncü şəxsdə işlədilməsinə görə dialekt və şivələr iki qrupa ayrılsalar da, demək olar ki, bütün qruplarda bu şəkilçi eyni variantlarda meydana çıxır, bəzi dialektlərdə çox cuzi fərqlər nəzərə çarpır. Həmin şəkilçilər bütün sözlərdə -dl, -di, -du, -dü kimi özünü göstərir (2, s. 162).

\section{Notico}

Sintaktik cəhətdən dialekt və şivələri təhlil etsək, görərik ki, onları ədəbi dildən ayıran əsas cəhət fikri ifadə edərkən birinci, ikinci, üçüncü şəxslə ifadə olunan mübtədanın işlədilməməsi və fikrin bir başa xəbər vasitəsilə ifadə edilməsidir. Xəbərdə olan elementlər və subyekt vasitəsilə fikrin kimə məxsus olduğu aydın şəkildə başa düşülür. Bəzən isə xəbərlik buraxılır və predikat intonasiya vasitəsilə ifadə olunur.

\section{Odəbiyyat}

1. Obülfəz Rəcəbli. Sosiolinqvistika. Baki, Nurlan 2004, səh. 343, 374.

2. Məmmədağa Şirəliyev. Azərbaycan Dialektologiyasının əsasları. Bakı, 2008, səh. 162

3. Sarwat un Nisa, King Khalid University, Sociolinguistics 2019, p.4 
Ayton Tahir quzı Korimli

Gəncə Dövlət Universiteti

dissertant

aytenkerimli14@gmail.com

\title{
TÜRK DILLINDӘN KEÇəN SÖZLəRIN LEKSİK-SEMANTIKK FUNKSİONALLIĞI
}

\begin{abstract}
Açar sözlor: leksik-semantik funksionallıq, məna dəyişikliyi, müxtəlif sistemli dillar, resipiyent dil, kommunikativlik
\end{abstract}

\section{Lexico-semantic functionality of words transferred from the Turkish language Summary}

The functional qualities of words transferred from the Turkish language are more evident in terms of content. These qualities have two different forms of manifestation. In one case, lexical units are expressed along with all meaningful parameters. In their indicators of content, the differentiation of related languages comes to the fore. Among the factors contributing to lexicalsemantic differentiation in both related languages, the semantic development of words plays an important role, which, in turn, leads to a change in the semantic parameters of a particular language and leads to differences in the related language, in which the semantic balance is disturbed. Among the lexical units that are stable in meaning, an important place is occupied by words that do not have an equivalent in the Azerbaijani language.

Key words: lexical-semantic functionality, change of meaning, multi-system languages, recipient language, communication

Türk dilindən gələn sözlərin funksional keyfiyyətləri məzmun planında daha çox üzə çıır. Bu cür keyfiyyətlər bir-birindən fərqli iki təzahür formasına malikdir. Bir halda leksik vahidlər bütün məzmun - məna parametrləri ilə birlikdə dilə gəlir. Onların məzmun göstəricilərində qohum dillərə məxsus diferensiallıq ön sırada dayanır. Hər iki qohum dildə leksik-semantik diferensiallığ 1 şərtləndirən amillər içərisində sözlərin mənaca inkişafı mühüm yer tutur və öz növbəsində dillərin gah birində, gah da digərində məna parametrlərinin dəyişilməsinə səbəb olur və semantik tarazlı̆̆ın pozulduğu qohum dildə fəqlənmələrə gətirib çıxarır. Azərbaycan dilində güc sözü "insanın fiziki enerjisi", "qüvvə" mənasındadır (1, s.299). Müasir türk dilində güç "qüvvə", "çətin, müşkül”" mənalarını ifadə edir. Bununla belə, "dövlət" anlamını da bildirir. Sonuncu anlam birbaşa leksik vahidin müstəqim məna yükundən təşəkkül tapır. Yeni anlamın fonetik tərkibə transformasiyası həm də üslubi cilalanmadan keçir. Bu səbəbdən leksik vahid sadəcə "dövlət" yox, iqtisadi, siyasi, hərbi baxımdan böyük əhəmiyyətə və digər dövlətlər içərisində təsirə malik siyasi təsisatı bildirir. Sözün semantik inkişaf xətti əlamətdən obyektə doğru istiqamətləndiyindən sonuncu (obyekt bildirən söz) ifadə olunmaya da bilir. Güc sözünün anlamı dövlət sözünün məna yükü ilə bərabərləşir (böyük gücü olan dövlət - güc). Bu səbəbdən Türkiyə türkcəsində olduğu kimi (və türkcənin təsiri ilə) Azərbaycan dilində də güc sözü "dövlət", "böyük qüdrətə malik siyasi təsisat" mənasını bölüşür. $\mathrm{Bu}$ fəlakətin arxasında böyük güclər dayanır; İspanlar və digər xristian güclər Quzey Afrikada müsəlmanları kütləvi surətdə qira-qıra gəlirdilər. (“Đdəbiyyat” qəzeti, 16.09.2017, № 32 (5103), səh.23; “Әdəbiyyat” qəzeti, 16.09.17, səh.20).

Sözün məcazi məna yükü Türkiyə türkcəsində yeni anlamın formalaşmasına səbəb olur. Çevrə sözü həqiqi məna (mərkəzdən eyni məsafədə olan qapalı əyri xətt. Bir şeyin kənarlarının əmələ gətirdiyi qapalı xətt) ilə yanaşı, bir şəxsin əlaqədə olduğu insanlar, əhatə olunduğu mühit anlamını da verir. Sözün yeni çalar qazanmasının səbəbi müstəqim məna ilə ortaq əlamətin mövcudluğudur. Bu səbəbdən məcazi anlam da (bir şəxsi əhatə edən insanlar) hərfi mənada qapalı əyri xətt kimi (bir şəxs ilə əhatədə olan insanları xəyalən birləşdirir) təsəvvür edilə bilər. (Məsələn: Adamların əksəriyyəti instinktiv olaraq onların baxışlarını paylaşan insanların çevrəsini və bu çevrədə öz yerlərini qoruyub saxlamağa çalışırlar; Onların eyni bir ədəbi çevrədə fəaliyyət göstərdiklərini 
gös̀tərir.). (“Әdəbiyyat qəzeti”, 10.06.2017, № 21 (5092), səh.19; “Әdəbiyyat qəzeti”, 06.05.2018, № 17 (5140), səh.26.).

Məna dəyişikliyi dil vahidinin öz leksik-semantik gücü hesabına baş verirsə də, kommunikativ gerçəkliyin də (dar anlamda kontekstin) rolu hər halda danılmazdır. Odur ki, daxili inkişafdan qaynaqlanan mənanın dəyişilmə xətti kontekst hüdudlarında sözə yeni üslubi rənglər qazandırır. Dəyər sözünün türk dilində "qiymət" mənasından başqa "maddi və mənəvi əhəmiyyəti olan”, "çox əhəmiyyətli" mənaları var. Prosesin əsasında əlamətin bir obyektdən digər obyektin üzərinə köçürülmə xətti dayanır. Ona görə də ədəbi-kommunikativ sistemdə köçürülmə obyektlərinin sayından asılı olaraq, məna tutumu dəyişə bilir (dəyər-qiymət, dəyər-abidə, dəyər-adət-ənənə, dəyər-din, dəyər-insan və s.). Azərbaycan dilinin lüğət tərkibində həqiqi məna (qiymət, məhsulun dəyəri, maya dəyəri və s.) funksional olsa da, son illərdə türk dilindəki anlamın işlənmə fəallığı artır (Məsələn: Mənəvi dəyərlərə söykənməyən prinsipsiz cəngavərdir). (“Odəbiyyat qəzeti”, 29 iyun 2019-cu il, № 22 (5197), səh.30).

Orəb, fars mənşəli alınmalar hər iki qohum dildə leksik-semantik diferensiasiyadan kənarda qalmır. Mənbə dildə bir neçə məna ilə səciyyələnən belə sözlərin mənaları adətən qohum türkcələr arasında paylaşdırılır. Odur ki, sözün mənalarından biri Azərbaycan türkcəsində işlənəndə digəri Türkiyə türkcəsinin payına düşür. Məsələn, ərəb mənşəli təcavüz sözünün mənbə dildə iki mənası özünü göstərir: "başqasının torpağına soxulma" və "namusa toxunma". Hər iki məna Türkiyə türkcəsində işlənsə də, Azərbaycan dilinin lüğət tərkibi üçün birinci məna daha xarakterikdir. Ancaq son onillikdə Türkiyə türkcəsinin təsiri ilə Azərbaycan dilində ikinci məna aktuallaşır (Məsələn: təcavüz qurbanı, təcavüz etmək, təcavüzə uğramaq və s.). Orəb dilində iqtidar sözünün də iki mənası mövcuddur: bacarıq, qüdrət və hakimiyyət. Müasir türk dilinin lüğət tərkibi üçün mənalar səciyyəvi sayılmaqla, hakimiyyət anlamı daha çox işlədilir. Azərbaycan dilində isə əksinə, "güc, qüdrət" mənası daha işlək olsa da, türk dilinin təsiri ilə son zamanlar digər məna leksik-semantik aktuallıq qazanır (məsələn: iqtidardakılar, iqtidar hökuməti və s.).

Azərbaycan dilinin lüğət tərkibində "nişan, nişangah" kimi qeydə alınan hədəf sözünün türk dilində işlək olan "məqsəd, qayə" anlamı Azərbaycan dilinə keçir (Bütün fəaliyyətimizin hədəfi milli və islami dəyərlərimizin qorunmasına yönəlib.). (“İki sahil” qəzeti. 12.08.2017, № 144 (6910), səh.6.).

Digər halda söz Azərbaycan dilində leksik-semantik inkişafa uğrayır və türkcədəki məna qarşılığından fərqlənir. Fars dilinə məxsus "güc" mənasında zor sözündən düzələn zorlamaq feili türk dilində "məcbur etmək", "zor tətbiq etmək" mənasını ifadə edir. Azərbaycan dilində isə həmin semantik sahə hüdudlarında formalaşmış "cinsi təcavüz" anlamında çıxış edir.

Mənaca sabit qalan leksik vahidlər içərisində Azərbaycan dilində ekvivalenti olmayan sözlər mühüm yer tutur. Tədqiqatlarda belə sözlərin üç tipi səciyyələndirilir: I tip - söz-realilər (Bir dil daşıyıcılarının təcrübəsində olmayan predmet və hadisələr digər dilə məxsus sözlərlə ifadə olunur); II tip - təsadüfi ekvivalentsiz sözlər (Müxtəlif dillərdə tərkib hissələrinə üzvlənmə reallıqdakı kimi üst-üstə düşmür); III tip - struktur ekzotizmlər (Bir dildəki predmet, hadisələrin adlarının analoji şəkildə digər dildə ifadəsi mümkün olmur) (2, s.71). L.Malıx və D.Medvedevanın birinci tipə aid etdiyi nümunələrin oxşarı qohum türkcədən gələn sözlərin içərisində müşühidə edilir. Fərqləndirici cəhət odur ki, anlayış və onun ifadə olunduğu söz (və ya sözlər) Azərbaycan dili üçün yeni sayılır. Məsələn, imza günü türk dilində yazarların satışa çıxan əsərlərini xatirə olaraq imzaladıqları günü bildirir. Azərbaycan dili daşıyıcılarının yaşadıqları cəmiyyət, mühit üçün bu cür tədbir səciyyəvi deyildi. Yalnız son onillikdə prosesin Azərbaycan mühitinə keçməsi ilə ona məxsus ad göstəriciləri də publisist üslubda görünməyə başlayır. 2000-ci illərə qədər Azərbaycan jurnalistikası üçün səciyyəvi olmayan köşə yazarı ifadəsi də bu cür nümunələrdəndir. Birləşmə türk dilində "qəzet və jurnallarda gündəlik əhəmiyyətli mövzulardan bəhs edən əsasən ciddi (bəzən əyləncəli) yazı müəllifi”"ni bildirir. Birləşmənin əmələ gəldiyi köşə yazısı ifadəsi hərfən "qəzetin bir küncünü tutan yazı" deməkdir. Məsələ bundadır ki, birləşmənin komponentləri ayrı-ayrılıqda Azərbaycan dilinin lüğət tərkibi üçün yad deyil. Ancaq belə struktur tərkibdə birləşmə modeli də Azərbaycan dilinin sintaktik quruluşu üçün səciyyəvi sayılmır. Qohum Azərbaycan və türk dillərində ikinci tipə aid 
söżlərə təsadüf edilmədiyindən onları başqa cür də səciyyələndirmək olar. Reallıqdakı hadisələrin adları Azərbaycan və türk dillərində bəzən üst-üstə düşmür. Məsələn: ad günü (Aərbaycan dilində) - doğum günü (türk dilində). Bu ondan irəli gəlir ki, etnosların hər birində obyektiv gerçəkliyə özünəməxsus baxış tərzi formalaşır. Yəni azərbaycanlılarla Türkiyə türkcəsinin dil subyektlərinin obyektiv gerçəkliyin predmet və hadisələrinə baxış bucaqları fərqli düşüncə və dərketmə tərzindən qaynaqlanır. Bu səbəbdən eyni hadisəni adlandırmaq üçün bir dildə advermə / adqoyma (fərdi nominasiya; məsələn: ad günü), digər dildə dünyaya gəlmə (məsələn: doğum günü) əlamətləri əsas götürülür. Yaxud başqa bir halda tərəzinin göstəricilərinə (kilo almaq - kilo vermək) və insan bədəninin ölçülərinə (kökəlmək - arıqlamaq) görə ifadə olunma adlandırmada mühüm yer tutur. Belə fərqliliklər qohum olmayan dillərdə daha aydın nəzərə çarpır. Məsələn: ingilis dilində: housekeeper (hərfən evi qoruyan) - Azərbaycan dilində ev sahibəsi, müvafiq olaraq begger (hərfən yalvaran; ingilis dilində) - dilənçi (Azərbaycan dilində) və s.

Dünya dillərində alınma sözlərə aid əksər funksional xüsusiyyətlər bəzən üst-üstə düşür. Onlar sözalan dildə müxtəlif uyğunlaşmalara məruz qalır, müxtəlif sahələrə aid leksik və terminoloji vahidləri əhatə edir, semantik cəhətdən, yaxud morfoloji quruluşca dəyişmələrə uğrayır (və ya uğramır). Alınma vahidlərin dilə gəlmə səbəblərinin eyniliyi də bu baxımdan qohum və qohum olmayan dillərdə ümumilik (ortaqlıq) təşkil edir. Tədqiqatlarda müxtəlif sistemli dillərə aid bir sıra səbəblər göstərilir (3, s.134). Səbəblərdən birincisi yeni əşya və anlayışların alınması ilə əlaqədardır. Türkiyə türkcəsindən Azərbaycan dilinə keçən sözlərin müəyyən qismini belə vahidlər təşkil edir. Məsələn: Həyat bilgisi (orta ümumtəhsil məktəblərində tədris olunan fənnin adı), Çağrı mərkəzi , atəşkəs, çevik alay, köşə yazarı, imza günü və s. İkinci səbəb terminologiya üçün istifadə olunan dubletlərlə bağlıdır. Azərbaycan dilindəki milli, yaxud Avropa (bəzən Şərq) mənşəli qarşılıqları ilə yanaşı işlədilir: bilgisayar - kompüter, soyqırım - genosid, yetərsay - kvorum, orqan nəqli - bədən üzvünün köçürülməsi, küvet - təknə və s. Növbəti səbəb bu və ya digər məna çalarını qabartmaq cəhdini əhatə edir. Türk dili sözlərinin bəzisi resipiyent dildə üslubiləşir, sözün konkret nominativ mənası yox, ondan doğan çalar üslubi ifadə planına malik olur. Məsələn: uzman (Azərbaycan dilində ancaq tibb sahəsini əhatə edir), sənətçi (incəsənət sahəsinə aid söz kimi işlədilir); sayq1, sayın (bu sözlərdən Azərbaycan dili mətnlərində etiket kimi istifadə olunur), ödül (Türkiyədə təqdim edilən mükafat), olay (pis, qorxunc, mənfi çalarlı hadisə) və s. Sonuncu səbəb dəbin təsiri ilə əlaqədardır. Məsəslən: gələnək, törən, ipucu, amac, atış, eqo, aydın (ziyalı), kürəsəl, abartmaq, kültür, dərgi, etki və s. Belə sözlərin həm ana dilində qarş1lığı mövcuddur, həm də resipiyent dildə kommunikativliyə xidmət etmək şansı, ən azı hər hansı müddətə dildə qalmaq ehtimalı olmur. Onların dil vahidi kimi funksionallığı yalnız istifadə olunduğu mətnin sərhədləri ilə məhdudlaşır.

\section{Odəbiyyat}

1. Azərbaycan dilinin izahlı lüğəti, II cild, - Bakı: Şərq-Qərb, 2007.

2. Малых Л.М., Медведева Д.И. Структурно-семантическое моделирование близкородственных языков (на материале сербского и русского языков) // Вестник Челябинского государственного университета. Филология. Искусствоведение. Челябинск, 2011. № 37 (252), вып.61, (с.67-73).

3. Скрипочка Л.А., Джагарян М.В. Лингвистические заимствования как один из аспектов межкультурной коммуникации. Пятигорск: Университетские чтения, -2011. Январь, -c. 132-134.

4. "Odəbiyyat" qəzeti.

5. "Iki sahil" qəzeti. 


\title{
IQQTISADİ DIVERFIKASIYY İQTISADİ RAYONLARIN DINAMIK INNKIŞAFIN TəMINATÇISIDIR
}

\author{
Açar sözlor: iqtisadi diverfikasiya, qeyri neft sektoru, məşğulluq, kand təsərrüfatı, sənaye
}

\section{Economic diversification is a supplier of dynamic development of economic regions Summary}

Economic diversification is a tool to eliminate dependence on a single product and service that affects the economic development of the country. Economic diversification, established through the proper allocation of economic factors and resources, not only eliminates the country's dependence on imports, but also affects its dynamic development. New production relations are being formed, the level of employment among the population is rising, the population's sources of income are increasing and the volume is increasing, the process of suburbanization is accelerating, and relative environmental pollution is being prevented. It also contributes to the positive development of economic growth and creates a basis for changes in GDP.

Key words: economic diversification, non-oil sector, employment, agriculture, industry

\section{Giriş}

İqtisadi şaxələndirmə, iqtisadiyyatın vahid gəlir mənbəyindən aslılığı aradan qaldırmaqla getdikcə artan sahələr və bazarlardan çoxsaylı mənbələrə keçid prosesidir. İqtisadi şaxələndirmə uzun müddət aşağı və orta gəlirli iqtisadiyyatlar üçün siyasət prioriteti kimi qəbul edilmişdir. Beynəlxalq Valyuta Fondunun (BVF) idarəedici direktoru Kristin Laqard 2017-ci ildə Afrikadak1 iqtisadi şaxələndirmə ilə bağlı bir çıxışında "İqtisadi şaxələndirilməni təşviq etmək gözəl bir ənənəvi parça toxumağa bənzəyir. Daha mürəkkəb, daha dayanıqlı və bütün ailələr və cəmiyyətlər üçün daha faydalı bir iqtisadi toxuma toxumaq deməkdir. İqtisadi şaxələndirmənin ölkə iqtisadiyyatının dayanıqlı və davamlı böyüməsi üçün yaxşı vasitə olduğunu bilirik. Ümumilikdə, hər hansı bir iqtisadiyyatı şaxələndirmək üçün ölkənin struktur xüsusiyyətləri nəzərə alınmaqla iqtisadi və siyasi strategiyaların spesifik ölçülərinin müəyyənləşdirilməsindən asılıdır (1).

Son illər dünyada baş verən siyasi və iqtisadi prosesslər iqtisadi şaxələndirməni prioritet bir sahəyə çevirməklə bir çox neft və mineral baxımından zəngin iqtisadiyyatlara malik olan ölkələr də ixracat mənbələrini və maliyyə gəlirlərini genişləndirərək bu təbii sərvətlərdən asılılığı azaltmağ1 hədəfləyirlər. Yerləşdiyi ərazi qurluşunun imkalarından, malik olduğu təbii sərvətlərin istifadə dərəcəsindən, göstərə biləcəyi xidmətlərin həcmindən, turizm gəlirlərindən və ya bir neçə işlənməmiş əmtəə ixracatından asılılıqlarını azaldaraq daha güclü, davamlı iqtisadiyyatlar qurmağa çalışırlar.

İqtisadi şaxələndirmənin inkişafına təsir edən bir necə amillər var bu amillər, adambaşına düşən gəlir; institusional inkişaf; maliyyə, fiziki və insan kapitalı; bərpa olunan və olunmaya təbii ehtiyyatalar; demoqrafik vəziyyət; yerləşdiyi coğrafi ərazi qurluşu; siyasi və iqtisadi sistem və digərləri.

\section{Quba-Xaçmaz iqtisadi rayonun iqtisadi şaxələnmə istiqamətləri}

Onənəvi olaraq, iqtisadi şaxələndirmə xam neft, minerallar və kənd təsərrüfatı istehsalı kimi bir və ya bir neçə əmtəədən asılılıqdan daha geniş istehsal, məşğulluq, ticarət, gəlirlər və xərclər mənbələrinə keçidi əhatə edir. İqtisadçıların fikirincə iqtisadi şaxələndirmə siyasəti ilə sıx əlaqəli olan proses məhsuldarlığın artması, istehsalın davamlı böyüməsi və daha geniş inkişafı ilə xarakterizə olunan struktur çevrilməsidir (2). 
Son illər Azərbaycanın iqtisadi baxımından enerji sahəsində beynəlxalq səviyyəli çox böyük layihələrin icra etməsi inkişaf etmiş ölkələrlə iqtisadi əlaqələrini genişləndirməklə beynəlxalq bazarlara qoşulma imkanalrımızı artırımış oldu. Mövcud iqtisadi resusrslar hesabına milli iqtisadiyyatın qorunub saxlanılması və beynəlxalq bazarlarda dayanıqlı̆̆ın təmin olunması daim diqqətdə saxladığı vacib amillərdən biridir. Daim dəyişən iqtisadi prosesslərə uyğunlaşmaq üçün mövcud imkanlarını düzgün səfrəbər etmək düzgün addım olardı. İqtisadi diverfikasiya milli iqtisadiyyatın neft və neft məhsillarından aslılığını aradan qaldırmaqla bərabər iqtisadi rayonların inkişafına da müsbət təsir göstərməklə ölkənin iqtisadi dinamikliyini artırmış olacaq. Bu baxımdan Azərbaycanda iqtisadiyyatın və ixracatın şaxələnməsinə təsir göstərə biləcək 40-dən artıq qanun qəbul edilib. Bunların arasında mikro kiçik və orta sahibkarlığa dövlət köməyi; maliyyə-sənaye qrupları; xüsusi iqtisadi zonaların yaradılması, regional sənaye parkların qurulması, aqroparkların istifadəyə verilməsi məsləhət xidmətlərin göstərilməsi, logistik mərkəzlərin yaradıllması, kənd təsərrüfatı məhsul istehsalçıları üçün tədarükü məqtəqələrin qurulması və kənd təsərrüfatı məhsulları istehsalçılarına müddətli vergi güzəştlərinin tətbiq edilməsi və sairə bu kimi qanunlar imzalanmış və icra olunuşdur. Bu qanunlar ümumi iqtisadi səviyyədə iqtisadi şaxələnmənin təməlini yaratmaq üçün önəmli sayıla bilər. Bundan başqa, həmin dövrdə sektorial əhəmiyyətə malik qanunlar qabul edilib ki, bunların sırasında energetika; rabitə; turizm; toxumçuluq; taxıl; pambıqç1lı; üzümçülük və şərabçılıq; çayç1lıq; damazlıq heyvandarlıq və arıçılıq haqqında qanunları aid etmək olar (3).

Regionların sosial-iqtisadi inkişafı üzrə icra olunmuş Dövlət Proqramları iqtisadiyyatın müxtəlif sahələrinin inkişafı, həmçinin sosial və kommunal infrastrukturun yenidən qurulması əsasında regionlar arasında tarazlığın inkişafını təmin edilməsini qarşıya əsas məqsəd kimi qoymuşdu. Dövlət Proqramların icrası zamanı ölkə iqtisadiyyatı üzrə regional inkişafda iqtisadiyyatın və ixracın diversifikasiya üçün milli və yerli xüsusuyyətlər nəzərə alınaraq aşağıda qeyd olunan konkret inkişaf istiqamətləri nəzərdə tutulub:

$\checkmark$ kənd təsərrüfatı sektoru (bitkiçilik, heyvandarlıq və quşçuluq);

$\checkmark$ balıqçlıq və balıq sənayesi;

$\checkmark$ qida (aqrar), tütünçülük və şərabçılıq sənayesi;

$\checkmark$ yüngül sənaye, o cümlədən toxuculuq və ipəkçilik;

$\checkmark$ tikinti materiallarının istehsalı və tikinti məmulatları sənayesi;

$\checkmark$ kimya sənayesi;

$\checkmark$ cihazqayırma sənayesi;

$\checkmark$ turizm sektoru;

$\checkmark$ elektroenergetika sektoru;

$\checkmark$ rabitə və İKT;

$\checkmark$ "İnsan kapitalı"nın inkişafı ilə bağlı təhsil sektoru.

Beləliklə də 2000-2020-ci illərdə qəbul edilən dövlət proqramlarının və strategiyaların təhlili göstərir ki, bütün sənədlərdə istisnasız olaraq iqtisadiyyatın diversifikasiyasına nail olunması hökumətin iqtisadi siyasətinin prioritetini təşkil edib.

Öz növbəsində, dövlət proqramları və strategiyalarının təhlili onu da göstərir ki, hökumət iqtisadi diversifikasiyaya aşağıdakılar sayəsində nail olmaq niyyətindədir:

$>$ qeyri-neft sektorunda idxalı əvəzləyən məhsul istehsalının genişləndirilməsi;

- qeyri-neft məhsullarının ixracinın artırılması və qeyri-neft sektorunda ixracın diversifikasiyasının təmin olunmasi;

> ölkədə regional inkişafın təmin edilməsi, regionlar arasında tarazlı inkişafa nail olunması;

$>$ IKKT-nin və qabaqcıl istehsal texnologiyalarının tətbiqi sayəsində rəqabətə davamlı və yüksək texnoloji məhsulların istehsalı;

$>$ Region üzrə müasir tələblərə cavab verən təhlükəsiz nəqliyyat, maliyyə, turizm və digər xidmətlərin yüksək səviyyədə təşkili (3).

Quba-Xaçmaz iqtisadi rayonu aqrar sektor üzrə inkişaf etmiş və ixtisaslaşmış iqtisadi rayonlardan birisidir. İqtisadi rayona Quba, Qusar, Xaçmaz, Siyəzən və Şabran rayonları daxil 
olm̄aqla, rayonlar relyef qurluşuna, torpağın müxtəlifliyinə, təbii ehtiyatların zənginliyinə və sairə təbii amillərə görə bir-birindən çox fərqli xüsusuiyyətlərə malikdir. İqtisadi rayon müstəqillik illərinə kimi meyvə-tərəvəz məhsulların yetişdirilməsi və emalı, damazlıq, ətçilik və südçülük cinsləri üzrə iribuynuzlu və xırdadırnaqlı heyvanların saxlanılması və kəsim məntəqələri, quşçuluq fermaları və qeyd etdiyimiz sahələrin inkişafı ilə birbaşa əlaqəli olan maşın və avadanlıqların istismarı avtoparkları, xammalı və aralıq məhsulları son məhsul şəkilində emal edən aqrar-emal müəssisələri və yüngül sənayenin digər sahələri üzrə inkişaf etmişdir. Özəlləşmənin bəzi çatışmamazlıqlarını nəzərə almasaq ölkənin mövcud iqtisadi durumu və siyasi vəziyyəti nəzərə alınaraq uğurla davam edən özəlləşmə prosessindən sonra digər iqtisadi rayonlarda olduğu kimi Quba-Xaçmaz iqtisadi rayonda da iqtisadi baxımından böyük durğunluq yaşandı. Tam olaraq formalaşmayan sahibkarlıq münasibətləri özəlləşməsi nəticəsində malik olduğu əmlaklardan düzgün istifadə etməməsi, daşınan və daşınmaz əmlaka laqeyid yanaşması mülkiyyətdə çox ukladlığa mənfi təsir göstərmişdir. Uzun müddət kənd təsərrüfatına yararlı torpaqlar təyinatı üzrə istifadəsindən kənarda qalmış və ya təyinatı üzrə istifadə olunmamışdır.

Son 15-20 il ərzində dövlət tərəfindən imzalanan sərəncamlar, qəbul olunan qanun və qərarlar, uzun müddətli və mərhələli şəkildə icra oluna Dövlət proqramları regionların iqtisadi inkişafina səbəb oldu. Regionlarda sahibkarlıq subyektləri formalaşmağa başlandı xüsusi və şəxsi mülkiyyətin həcmi əsaslı formada dəyişdi, yeni istehsal münasibətləri yarandı. Həmçinin regionlarda qurulan sosial infrastruktur bölgələrin mövcud potensialından düzgün istifadəsinə imkan yaratmaqla pararel iqtisadi şaxələndirməni də sürətləndirdi.

İqtisadi rayonda son illər intensiv bağçılıq sürətlə inkişaf edir. Kənd təsərrüfatına yararlı torpaqların iqtisadi baxımından səmərəlik vəziyyəti nəzərə alınaraq rayonaların təbii xüsusuyyətinə uyğunlaşdılılmış yerli və xarici növ meyvə bağların sayı sürətlə artırılır. Onənəvi meyvə sortları ilə pararel iqlim şəraiətinə və quraqlığa davamlı yeni sort meyvə bağların üstünlük təşkil etməsi məhsuldarlığı artırmış oldu, həmdə daxili və xarici bazarlarda məhsulların rəqabətqabiliyyətlik səviyyəsinin gücləndirərək yeni xarici bazarlara çıxışa əlavə imkanlar yaratdı.

Son illər Quba-Xaçmaz iqtisadi rayonunda yeni salınan bütün növ meyvəçilik bağları İntensiv texnologiyalara əsaslanır. Yeni salnan meyvə bağları növündən və meyvənin sortundan asılı olaraq ilkin tələb olunan xərclər dəyişən və böyük məbləğ tələb etsədə, düzgün aqrotexniki qaydalara riayət olunmaqla çəkilən xərclər q1sa müddət ərzində özünü doğruldur və rentabelli bir sahəyə çevirdi. İntensiv bağçılıqda hektar üzrə düşən fiziki qüvvəyə olan təlabatı azaltmış olur. Qıt su ehtiyatından səmərəli istifadə edərək suya olan təlabatı maksimum ödəmiş olumaqla, bazarın istəyinə uyğun olaraq məhsul yetişidrməsinə imkan yaratdı. Kənd təsərrüfatına yararlı torpaq11rın intensiv üsulla dövriyyəyə daxil edilməklə iqtisadi rayon üzrə istehsal olunan meyvələrin çəkisində artım müşahidə olunur. Böyük ərazilərə malik meyvəçilik sahələrində meyvələrin saxlanıması üçün soyuducu anbarlarda meyvələrin uzun müddətə saxlanmasina şəraiət yaratmaqla meyvəçiliyin inkişafına təkan verib. Amma çox təəüssüflər olsun ki bölgələrdə emal müəssislərin olmaması meyvəçilik və tərəvəzçiliyin inkişafına mənfi təsir göstərir. İstər ikinci sort meyvə və tərəvəz məhsulları üçün istərsə də bazarda ilkin mərhələdə reallaşa bilməyən məhsulların emalı üçün aqraremal müəssisələrin fəaliyyət göstərməsi, sahibkarlıq subyektlərinə izafi xərclərini qarşılamağa şəraiət yaradacaq. Digər tərəfdən də ölkədə istehsal və ixrac olunan məhsulların nomenkulatuasına da təsir edəcək. Yəni bazara xammal kimi bir məhsul yox, emal olunduqdan sonra həmin məhsul əvəzinə bir neçə adda məhsul çıxarmaq olar.

Quba-Xaçmaz iqtisadi rayon meyvəçilik kimi heyvandarlığın inkişafı üzrədə böyük iqtisadi imkanlara malikdir. Bu sahədə istehsal oluna məhsulları isə istər ölkənin daxili bazarında istərsə də xarici bazarlarda təlabat daim yüksəkdir. Dövlətin rəsmi statistik rəqəmlərinə nəzər yetirdikdə görmək olar ölkə əhalisinin ət, süd və süd məhsullarına olan təlabatın çox hissəsi xaricdən idxal hesabına ödənilir. Azərbaycan Respublikasının Dövlət Gömrük Komitəsinin statistik hesabatlar bölməsində 2020-ci il üçün ən çox idxal olunan məhsulların siyahısında idxal olunan məhsullarının $15.29 \%$ yeyinti məhsullarıdır - (Cədvəl - 3). (4) 
IV Respublika EImi Qaynaqlar Konfransının Materialları / 30 iyun 2021

Materials of the IV Republican Conference of Scientific Sources / June 30, 2021

DOI: https://www.doi.org/10.36719/2663-4619/2021/02/04

\begin{tabular}{|c|c|c|c|c|}
\hline \multicolumn{5}{|c|}{$\begin{array}{c}\text { İdxalda əsas mallar } \\
\text { (min ABS dolları) }\end{array}$} \\
\hline \multirow{2}{*}{$\begin{array}{l}\text { XİF MN üzrə } \\
\text { malın kodu }\end{array}$} & \multirow[b]{2}{*}{ Malın adı } & \multicolumn{2}{|c|}{ 2020-ci il } & \multirow{2}{*}{$\begin{array}{c}\text { 2020-ci ilin } \\
\text { ümumi idxalına } \\
\text { nisbətən \%-lə }\end{array}$} \\
\hline & & Miqdar & $\begin{array}{c}\text { Statistik } \\
\text { dəyər }\end{array}$ & \\
\hline & İdxal-cəmi & - & 10730720.22 & 100.00 \\
\hline \multirow[t]{2}{*}{$\begin{array}{l}02-04,07 \\
11,1201,1208,15-2\end{array}$} & $\begin{array}{l}\text { Yeyinti məhsulları, min ABŞ } \\
\text { dolları }\end{array}$ & - & 1640721.66 & 15.29 \\
\hline & Ondan: & - & - & - \\
\hline 02 & Әt, ton & 43948.45 & 78690.66 & 0.73 \\
\hline 0401-0402 & Süd, ton & 9657.31 & 15312.80 & 0.14 \\
\hline 0405 & $\begin{array}{l}\text { Kərə yağ1 və süddən } \\
\text { hazırlanmış digər yağlar, ton }\end{array}$ & 16806.39 & 82608.28 & 0.77 \\
\hline $07-08$ & Meyvə-tərəvəz, ton & 363143.45 & 203769.77 & 1.90 \\
\hline 0902 & Çay, ton & 13984.93 & 56187.15 & 0.52 \\
\hline 1001 & Buğda, ton & 1365100.13 & 296905.18 & 2.77 \\
\hline 1006 & Düyü, ton & 56884.28 & 38949.26 & 0.36 \\
\hline 15 & $\begin{array}{l}\text { Bitki və heyvan mənşəli } \\
\text { piylər və yağlar, ton }\end{array}$ & 166216.66 & 161924.00 & 1.51 \\
\hline
\end{tabular}

Cədvəl - 3

Cədvəldən də göründüyü kimi ilk üçlükdə dəyər və çəki nisbətlərinə görə ət, süd və süd məhsulları liderdir. Bu məhsullara görə idxaldan aslılığımız çox böyükdür. Bu aslılığı aradan qaldrımaq üçün dövlət tərəfindən sahibkarlıq subyektlərinin bu sahəyə təşviq görünür ki yetəri səviyyədə deyildi. Bu sahədə böyük təcrübəsi olan Almaniya , Hollandiya, Fransa, Danimarka və Türkiyə kimi dövlətlərin təcrüblərini öyrənməklə və yerli şəraiətə uyğunlaşdırmaqla tətbiq etmək lazımdır. Dövlət proqramı tək xaricdə yetişdirilmiş cins malların ölkəyə gətirilməsi ilə yox, ökənin iqlim şəraiətinə və relyefinə uyğunlaşdırılmış cinslərin yetişdirilməsi, intensiv texnologiyaların tətbiq hesabına yem məhsulların məhsuldarlığının artırılması, maşın və texnoloji avadanlıqların güzəştli şərtlərlə sahibkarlıq subyektləər verilməsinin təşkil və kadrlar arasında təcrübə mübadiləsini aparılması istiqamətində davam etməlidir.

Quba - Xaçmaz iqtisadi rayonu təkçə aqrar sahə üzrə inkişaf potensialına malik deyil, bölgənin inkişaf istiqamətləri və sahələri müxtəlif olduğundan iqtisadi şaxələnmə potensialı böyükdür. Bölgənin beynəlxalq səviyyəli magistiral avtomabil və dəmir yolların üzərində yerləşməsi logistika xidmətlərin inkişafına təsir edir; təbiətin müxtəlifliyi dağlıq ərazilər, meşə ehtiyatı və Xəzərə dənizinə çixişi qış və yay turizminin inkişafını sürətləndirir; meyvəçilik, bağçılıq və heyvandarlığın inkişafı yüngül və yeyinti sənayenin inişafına təsir edir; pararel olaraq sığorta, maliyyə, bank və konsalting xidmətləri inkişaf edəcək. Ümumilikdə götürdükdə isə iqtisadi şaxələnmə üzrə rayonun iqtisadi potensialı çox böyükdür.

\section{Naticə}

İqtisadi şaxələndirmə daxili istehsalı, xidməti, ticarət və digər sahələri fərqli bir qurluşa daxil etməklə məhsuldarlığı artırmaq, yeni iş yerləri açmaq, fərqli iştirakşıların iştirakına imkan yaratmaq, geniş tərkibdə məhsul istehsal dəyər zəncirinin yartamqla ölkəmizin davamlı inkişafı üçün əlavə imkanlar yaradacaq. Ölkə daxilində iqtisadi şaxələndirməni sürətlənməsi və səmərəliyinini artırılması nəticəsi olaraq iqtisadi rayonlar üzrə aşağıda qeyd olunmuş sahələrin sürətli inkişafına səbəb olacaq (5).

-İntensiv bağçılıq və meyvəçilik təsərrüfatların genişləndirilməsi təmin olunacaq;

-Müasir texnologiyalara əsaslanan meyvə-tərəvəz məhsullarının emalı müəssisələrinin sayı bütün rayonlar üzrə artacaq; 
-Maşın və avadanlıqların yenidən hazırlığı üzrə texnoparklar qurulacaq;

- Otlik və südlük istiqamətində müasir heyvandarlıq kompleksləri yaradılacaq;

- Elmi tədqiqat institutların və laboratoriyaların sayı artacaq;

- İqtisadi rayonlar üzrə ixtisaslaşmış Azad iqtisadi zonalar formalaşacaq;

- İqtisadi subyektlərin malliyə və digər resurslara çıxış1 sadələşəcək və iştirakında bərabər şəraiət yaranacaq;

- Mütəxəsisli kadrların xüsusən baytar, zootexnik və aqronom kimi ixtisaslı kadrların hazırlığına təlabat artacaq.

\section{Odəbiyyat}

1. https://carnegieendowment.org - Economic Diversification in Africa: How and Why It Matters pdf Aprel, 2021.

2. https://www.semanticscholar.org - Economic Diversification: Lessons From Practice pdf - 2019

3. İqtisadiyyatın və İxracın diversifikasiyasının qiymətləndirməsi - 2013. K.Aslanl1, Z.İsmayıl, R. Ağayev. A.Mehdiyev

4. https://www.customs.gov.az

5. https://static.president.az - Azərbaycan Respublikasının milli iqtisadiyyat perspektivi üzrə Strateji Yol Xəritəsi. 


\section{AZORBAYCAN NAĞILLARLINDA SEHRLİ TILSIM VASITOLORİ}

Açar sözlər: nă̆ll, Azərbaycan nă̆lllarl, sehr, tilsim, çubuq, toxmaq, ceviz, düdük, dolça, güzgü, üzük

\section{Magical spells in Azerbaijani fairy tales Summary}

A number of mythical characters are used as spells in Azerbaijani fairy tales: a) The hero opens the door enchanted by the divine with a magic band; b) The enchanted girl turns the witch into a needle through a magic tree; c) The magic wand awakens it's owner, the sorcerer, and warns him of the dangers; d) The hero stuns the mother of the divine with the water in a magic walnut, and the other escapes persecution by creating a forest with the dust in the walnut; d) The shepherd saves his friends from death by recognizing the vessels containing poisonous food through the magic whistle; e) The girl resurrects the beheaded hero through a magic jug; g) The magic mirror shows all the secret works of the world; f) The magic ring obeys any order of its owner. Although these magical objects perform different functions, they have one thing in common: they are all magical, and their magical power is the power of that magic.

Key words: fairy tale, Azerbaijani fairy tales, magic, enchantment, wand, hammer, walnut, whistle, aquarius, mirror, ring

\section{Giris}

Azərbaycan nağıllarında sehrli əşyaların bir qismindən tilsim yaratmaq məqsədi ilə istifadə olunur. Belə əşyaların sayı çoxdur. Bəzilərinə diqqət etməklə onların mifik xarakteristikasını müəyyənləşdirməyə çalışaq.

\section{Tədqiqat}

"Sehrli alma" nağılında qəhrəman göyərçin qızların ona öyrətdiyi kimi hərəkət edərək, div qarısının quyuda qoruduğu sehrlu çibuğu oğurlayır (AFK-I, 2006: s. 260). Sonra o, həmin çubuğu üç dəfə divin sarayının qapısına vurmaqla onu açmağa nail olur (AFK-I, 2006: 260).

Göründüyü kimi, burada sehrli çubuğun mifik xüsusiyyəti onun vasitəsilə divin tilsimlə bağladığı qapının qeyri-adi üsulla açılmasında ifadə olunur. Yəni burada sehrli çubuq tilsim vasitəsi kimi açar rolunu oynayır.

Çubuq, əlbəttə, ağac budağıdır. Ona görə də nağıllarda bəzən sehrli çubuğa sehrli ağac adı altında rast gəlirik. Məsələn, "Sehrli güzgü” nağılında tilsimkar padşah q1zı sehrli ağacın vasitəsilə cadugəri iynəyə çevirir: "Cadugər yenə gəlir qızın yanına ki, bir padşah var, deynə qardaşına, onun qızını alıb gətirsin, qız olsun sənə qulaq yoldaşı. Sən demə, bu padşah qızı tilsimli imiş. Oğlan min bir zülümnən bu qızı da alır. Cadugər bu dəfə də qızın yanına gələndə tilsimli padşah q1zı əlindəki ağacı vurur ona, deyir:

- İynə ol!

Cadugər iynə olur, q1z götürüb onu gizlədir” (AFK-VII, 2008: 141).

Nağıllarda sehrli tilsim vasitələrindən biri toxmaqdır. "Üçayaq at" nağılında biz bu əşyaya cadugərin qoruyucusu kimi rast gəlirik. Qəhrəman padşahın qızını oğurlamış cadukünün qalaçasına gedir ki, qızı xilas etsin. O, qızla qaçanda toxmaq cadukünü xəbərdar edir: "Oğlan atı tərpədib yola düşən kimi, həmən cadugünün toxmağı tappa-turup salıb onu yuxudan oyatdı" (AFK-IX, 2008: 119). Birinci cəhd uğursuz alınır. Qəhrəman qızı ikinci dəfə qaçırır, bu dəfə də toxmaq cadukünü yuxudan oyadır (AFK-IX, 2008: 121). 
Cadukün - "cadugər" sözünün bir başqa deyiliş formasıdır. Cadugər cadu, tilsim edən deməkdir. Onlar cadu-tilsim zamanı müxtəlif əşyalardan istifadə edirlər. Həmin əşyalar tilsimli əşyalardır. Nağıldakı sehrli toxmağın mifik xüsusiyyəti öz sahibini təhlükədən xəbərdar etməkdir.

Sehrli cevizdən tilsim vasitəsi kimi istifadə olunmasına geniş şəkildə sehrli personajlarla zəngin olan "Sehrli alma" nağılında rast gəlirik. Bu nağılda qəhrəmanın sevdiyi q1zı div oğurlayaraq tilsimləyir. O, q1zı xilas etmək üçün yola düşür. Yolda göyərçinlər ona iki sehrli ceviz verib, ondan necə istifadə etməyi qəhrəmana öyrədirlər. Qəhrəman ona lazım olan sehrli çubuğu əldə etmək üçün tilsimli cevizlərdən istifadə edir: "Dönməz atına minif dəryanı keşdi. Az getdi, üz getdi, dərə-təpə düz getdi, yeddi gün, yeddi gejə yol getdi, göyərçinnərin dediyi quyunun yanına çatdı. Gördü div qarısı quyunun başında keşih çəkir. Cöyüzün birini sındırdı, içindəki suyu div qarısının üzünə atdı, div qarısı yerə yıxıldı. Dönməz quyunun divinə enif çuvuğu götürdü. Atına minif yola düzəldi. Xeyli yol getdi, bir də gördü ki, arxadan gurultu gəlir, baxdı ki, toz-duman hər tərəfi basıf, qara divnən anası az qalıflar ona çatsınnar. Dönməz tez ikinci cöyuzü sındırıf içindəki tozu havaya soyurdu. O saat orada qalın bir meşə əmələ gəldi. Oradan heş quş da keçə bilməzdi” (AFK-I, 2006: 260).

Göründüyü kimi, hər iki ceviz tilsim vasitəsidir. Onların birinin içində su, o birisinin içində toz var. Suyu kimin üstünə atsan, onu keyləşdirir, tozu da atdıqda, o, keçilməz meşəyə çevrilir.

"Torçu oğlu" nağılında sehrli düdüyə rast gəlirik. Bu düdük tilsim vasitəsidir. Nağılda padşah qəhrəmanı və dostlarını öldürmək üçün onları qonaq çağırır. Padşah yeməklərə zəhər qatır. Lakin qəhrəmanın çoban dostu sehrli düdük vasitəsilə onları xilas edir: "Nə olajaxd1, padşah, bunnarı çağırdı qonax, məclis quruldu. Qavlar dolu qavağa gəldi. Çovan dedi:

- Qoyun bir az düdük çalım, mən düdük çalmasam, iştahım açılmır.

Dedilər:

- Yaxşı, çal.

Çovan başladı düdük çalmağa. O, düdük çalan kimi, xörək qavları başdadı oynamağa. Xörək qavları oynaşdıxca yerrərini dəyişdi. Zəhərli qavlar gedif vəzir-vəkilin qavağına düşdü, zəhərsizdər isə bunnarın qavağına. Hamı başladı yeməyə. Yemək qurtarmamış vəzir-vəkil öldü, bunnar yenə salamat qaldılar" (AFK-I, 2006: 101).

Göründüyü kimi, sehrli düdük tilsim vasitəsidir: o çalınanda qabları oynadaraq yerini dəyişir. Lakin sehrli düdük qabları sadəcə oynatmır, o həm də zəhərli yemək olan qabları tanıyaraq, onları vəzirlə vəkilin qabağına qoyur.

Nağıllarda sehrli dolçadan tilsim vasitəsi kimi istifadə olunur. Məsələn, "Pərilər padşahının q1zı" nağılında Pəri xanım dolçanın içindəki su ilə qəhrəmanı dilildir: "Cəllad Soltan Məliyin boynunu vurdu. Fərraşlar Soltan Məliyin başı ilə bədənini öyünə apardılar. Soltan Məliyin anası oğlunun meyidini görüb vay-şivən qopartdı. Pəri xanım fərraşlar gedənnən sonra Soltan Məliyin başı ilə bədənini birləşdirif üsdünə divin dolçasınnan su səpdi. Didi:

- Süleyman peyğəmbərin eşqinə, diril!

Pəri xanım sözünü diyib təzəcə qurtarmışdı ki, Soltan Məliy dirildi” (AFK-I, 2006: 176).

Burada iki mifik cəhət diqqət çəkir:

Birincisi, qəhrəman dolçanın içərisindəki sehrli su vasitəsilə dirilir. Bu su nağl1llarda abi-həyat, yaxud dirilik suyu adları altında göstərilir. Həmin su dolçanın içərisindədir. Ona görə də tilsim vasitəsi kimi dolçanı görürük.

İkincisi, sehrli vasitələr, tilsimli əşyalar əvvəlcə şər qüvvələrin əlində olur. Bu nağılda da Pəri qızının istifadə etdiyi sehrli dolçanın əsil sahibi divdir.

Nağıllarda sehrli güzgüdən tilsim vasitəsi kimi istifadə olunması ilə tez-tez qarşılaşmaq olur. Bir nümunəyə diqqət edək. "Sehrli güzgü” adlı nağılda deyilir ki, bir padşah var idi. Padşah əhd etmişdi ki, oğluna üç bacını alsın. Parşah oğlunu üç bacı ilə evləndirir. Kiçik qız əkiz uşaq doğur: biri qızıl saçlı q1z, o birisi - gümüş saçlı oğlan. Böyük bacılar ona paxıllıq edirlər. Onlar cadugərin vasitəsilə uşaqları dəyişdirib, yerinə bir cüt küçük qoyurlar. Padşahın oğlu da hirslənib, kiçik qızı evdən qovur. Cadugər uşaqları sandığa qoyub, çaya atır. Sandıq bir balıqçının toruna düşür, o da həmin uşaqları övladlığa götürür. Oğlan böyüyüb, mahir ovçu olur. Böyük bacılar uşaqların 
ölm̄ədiyindən xəbər tutur və cadugəri qızın yanına yollayırlar. O da qızın qardaşını gedər-gəlməzə yollamaq üçün onu yoldan çıxarır ki, qoy qardaşın gedib “dünyanı göstərən güzgünü” gətirsin, sən də baxıb darıxmayasan. Qızın qardaşı güzgünü tapıb gətirir. Bacı-qardaş güzgüyə baxıb, orada analarını görürlər. Hadisələrin sonrakı inkişafında padşah oğlu da güzgüyə baxır və orada vaxtilə evdən qovduğu arvadının şəklini tanıyır. Nağılın sonunda paxıl böyük bacılar və onlara kömək edən cadugər öldürülür, padşah oğlu isə öz ailəsinə yenidən qovuşur (AFK-VII, 2008: 139-142).

Nağılda sehrli güzgü süjet hadisələrinin inkişafında böyük rol oynayır. Güzgü ilk dəfə uşaqların itmiş anasını onlara göstərir, daha sonra isə padşah güzgü vasitəsilə bütün xəyanətlərdən xəbər tutur. Güzgünün mifoloji xüsusiyyəti onun dünyanı göstərməsidir. Yəni bu, elə bir güzgüdür ki, dünyada baş verən bütün sirli, gizlin hadisələri açıb göstərə bilir.

Güzgü bu xüsusiyyətə təkcə folklorda malik deyildir. O, təsəvvüfdə hətta psixoloji-irfani obraza çevrilmişdir. Maarifə Hacıyeva və Mehmet Rıhtım yazırlar ki, təsəvvüfdə kamil insanın qəlbinə ayna, yəni güzgü deyilir (Haciyeva... 2009: 58).

Sehrli güzgüdən tilsim vasitəsi kimi istifadə olunmasına gəlincə, bu iki məqamla üzə çıxır:

Birincisi, sehrli güzgü haqqında ilk dəfə cadugər xəbər verir. O, qıza deyir ki, qoy qardaşın gedib, dünyanı göstərən güzgünü gətirsin. Cadugər - tilsim, cadu biliklərinə sahib olan adama deyilir. Ogər sehrli güzgü tilsim vasitəsi olmasaydı, cadugər belə bir güzgünün varlığından xəbər tuta bilməzdi.

İkincisi, nağılda qızın qardaşının evləndiyi padşah q1zı tilsimkardır. Nağılda qızın haqqında deyilir: "Sən demə, bu padşah q1zı tilsimli imiş" (AFK-VII, 2008: 141). Tilsimli qız sehrli çubuq və sehrli güzgüdən tilsim vasitəsi kimi istifadə edərək, bütün xəyanətlərin üstünü açır.

Qeyd etməliyik ki, bəzi nağıllarda sehrli güzgünü atanda o, dənizə çevrilir. Adətən, divlərin, ifritələrin təqibindən qurtulmaq istəyən qəhrəman güzgünü atır, güzgü də dəryaya çevrilərək şər qüvvələrin qarşısını kəsir.

Nağıllarda tez-tez tilsim vasitəsi olan üzüklərə də rast gəlirik. Bu üzüklər öz sahibinin verdiyi əmrləri dərhal yerinə yetirir. Sehrli üzüklər bu mifoloji cəhətinə görə bizə sehrli süfrə və sehrli kisəni xatlırladır. Onlar da öz sahiblərinin əmrini yerinə yetirərək çoxlu yeməklər, çoxlu pullar hazır edir. Lakin sehrli üzüklə sehrli xalça və kisə arasında mühüm bir fərq vardır. Sehrli süfrə və kisə qeyri-adi bərəkət yaratma vasitəsidir. Hər iki əşyanın yalnız bir xüsusiyyəti var. Belə ki sahibləri sehrli süfrədən yalnız çoxlu yemək, sehrli kisədən isə yalnız çoxlu pul istəyə bilərlər. Bu sehrli əşyalar bundan artığına qadir deyil. Bu baxımdan, sehrli süfrə və sehrli dolçanın əsas mifik xassəsi onların yalnız bir funksiyasında, yəni sehrli bərəkət yaratmasında ifadə olunmuşdur. Sehrli üzüyə gəlincə, bu, bir tilsim vasitəsidir. Sehrli üzük öz sahibinin istənilən əmrini yerinə yetirir. Nümunələrə müraciət edək.

"Daş üzük" nağılının xeyirxah, rəhmdil qəhrəmanı olan keçəl ilanlar padşahının qızını içərisində uzun müddət əsir qaldığı qutudan xilas edir. $O$, bunun əvəzində q1zın atasından onun dilinin altında saxladığı daş üzüyü alır. Bu üzük sehrlidir. Lakin üzüyün sehrli olduğunu bilməyən keçəl onu yolda bir kişinin verdiyi çörəyə dəyişir: "Elə ki, keçəl getdi, birdən qızın yadına düşdü ki, heç mən keçələ demədim, üzüyün xasiyyəti nə təhərdi. Tez fişəng kimi uça-uça fişş eləyib, keçəlin yanında yerə endi. Tez keçələ dedi:

- Keçəl, üzüyü neylədin?

Keçəl dedi:

- Acıdım, verdim bir kişiyə, çörək aldım yedim.

İlan keçələ bir goppa (qapaz - Y.Oləkbərov) vurub dedi:

- Vay sənin evin yıxılsın, keçəl, kişi hayana getdi?

Keçəl kişinin getdiyi tərəfi göstərdi. İlan yenə fişəng kimi göydə fişş eləyib, həmin kişinin yanında düşdü. Tez kişini vurdu, kişi öldü. Üzüyü götürdü, yenə göydə fişş eləyib keçəlin yanına gəldi, üzüyü keçələ verib dedi:

-Keçəl, bu üzüyü heş kimə verməzsən. Elə ki, suya girdin, təmiz çimdin, ondan sonra ürəyində hər nə tutsan, desən: "Üzük, səndən istəyirəm”, o saat hazır olar, amma üzüyü bir adama versən, evin yıxıldı, ilap (lap - Y.Oləkbərov) iki gözün olsa, üzüyü vermə” (AFK-VIII, 2008: 370-371). 
- Keçəl bu üzükdən bir neçə dəfə istifadə edir. Üzük müxtəlif vaxtlarda ona aşağıdakıları hazır edir:

a) Keçəlin özü və anası üçün ayran aşı və plov (AFK-VIII, 2008: 371);

b) Keçəlin qızını istədiyi padşahın tələb etdiyi yeddi mərtəbəli bir ev (AFK-VIII, 2008: 373);

c) Padşahın qızı üçün cevizin içərisində nə qayçıdan, nə də iynədən istifadə olunmadan hazırlanmış iki dəst paltar (AFK-VIII, 2008: 373).

Nağılda şər funksiyalı qarı keçəlin arvadına gözü düşmüş Hindistan padşahının oğlunun sifarişi ilə keçəlgilin etbarın qazanır və üzüyü oğurlayır. Üzük qarının əmri ilə onların hamısını Hindistana aparır (AFK-VIII, 2008: 374).

Göründüyü kimi, bu epizodda üzük artıq sehrli xalçanın funksiyasını yerinə yetirir, yəni medisaiya vasitəsi kimi çıxış edir.

Üzüyün sehrli xüsusiyyətindən hətta siçanlar da istifadə edir. Belə ki, üzüyü oğurlamış qarının otuz-qırx siçanı var idi. Qarı üzüyü siçanlara vermişdi. Onlar üzük vasitəsilə dil açmışdılar (AFKVIII, 2008: 376).

Qeyd edək ki, nağılda üzük gah xeyir, gah da şər qüvvələrdə olur. Hər iki halda üzük öz sahibinin əmrlərini yerinə yetirir. Bu nağılda da sehrli üzüyün əsl sahibi o biri dünya, sehrli dünya varlığıdır. Belə ki, sehrli üzüyün ilk sahibi keçəlin xilas etdiyi ilan-qızın atasıdır. O, ilanlar padşahıdır.

"Sehrli üzük" nağılındakı üzük də öz sahibinin bütün əmrlərini yerinə yetirir. Nağılda deyilir ki, bir yoxsul kişi var idi. Kişinin Fatma adında çox gözəl bir arvadı vardı. Bir lotunun Fatmaya gözü düşür. Həmin lotu eynilə "Daş üzük" nağılında olduğu kimi, bir bədxah qarını Fatmanı ələ keçirmək üçün onlara yollayır. Qarı özünü yazıq göstərib, onların evinə daxil olur. O, tezliklə ailənin etimadını qazanır və bu yolla Fatmanın sirrini öyrənir. Məlum olur ki, Fatmanın ona "anasından qalma bir sehrli üzüyü vardı. Bir gün qarı xəlvətcə sehirli üzüyü qızdan xəlvəti oğurlayıb, öpüb dizinin üstünə qoydu, dedi:

- Ey üzük, Həzrət Süleymanın eşqinə, pişiynən, tulasıynan Fatmanı lotu kişinin qapısında istiyirəm.

Fatma gördü ki, pişiynən, tulasıynan qalxdı havaya" (AFK-III, 2006: 205).

Bu nağıldakı hadisələr eynilə "Daş üzük" nağılındakı kimi cərəyan edir. Bu nağılda da qarının siçanları var. Siçanlar üzüyün yerini bilir. "Daş üzük" nağılında keçəlin dil bilən tulası və pişiyi olduğu kimi, burada da Fatmanın ərinin dil bilən tulası və pişiyi var. Hər iki nağılda pişik və tula sehrli üzüyün əldə edilməsində və şər qüvvələrin cəzalandırılmasında mühüm rol oynayırlar.

"Sehrli üzük" nağılında sahibinin tapşırığını dərhal yerinə yetirən üzüklərin məhz tilsim vasitəsi olması haqqında qiymətli bir məlumat vardır. Belə ki, nağılda sehrli üzüyün tilsimli olması açıq dillə deyilir. Bunu biz pişiklə tulanın dialoqundan öyrənirik:

"Pişik dedi:

- Ay tula, gedək xanımı lotunun əlindən qurtaraq.

Tula dedi:

- Necə qutaraq?

Pişik dedi:

- Onun tilsimi qarının barmağındakı üzükdədi. Gərək o üzüyü ondan alaq” (AFK-III, 2006: 205).

İlkin Rüstəmzadə Azərbaycan nağıllarının süjet göstəricilərindən bəhs edən tədqiqatında şumdan tapılmış üzük və Süleymün peyğəmbərin üzüyindən də bəhs edir. Hər iki əşya sehrlidir və hər iki üzük kimin barmağındadırsa - onun əmrlərini yerinə yetirir (Rüstəmzadə... 2013: 164). 
Beləliklə, nağıllarda bir sıra mifik personajlardan tilsim vasitəsi kimi istifadə olunur:

a) Qəhrəman divin tilsimlədiyi qapını sehrli çubuq vasitəsilə açır;

b) Tilsimli q1z sehrli ağac vasitəsilə cadugəri iynəyə döndərir;

c) Sehrli toxmaq öz sahibi olan cadugəri yuxudan oyadaraq, onu təhlükələrdən xəbərdar edir;

ç) Qəhrəman bir sehrli cevizin içindəki su ilə divin anasını keyləşdirir, o biri cevizin içindəki tozla meşə yaradaraq təqibdən xilas olur; edir;

d) Çoban sehrli düdük vasitəsilə zəhərli yemək olan qabları tanıyaraq, dostlarını ölümdən xilas

e) Q1z sehrli dolçanın vasitəsilə başı kəsilmiş qəhrəmanı dirildir;

ə) Sehrli güzgü dünyadakı bitün gizli işləri göstərir;

f) Sehrli üzük öz sahibinin istənilən əmrini yerinə yetirir.

Bu sehrli əşyalar müxtəlif funksiyaları yerinə yetirsə də, onları bir ümumi cəhət biləşririr: həmin əşyaların hamısı tilsimlidir, onların sehr gücü həmin tilsimin gücüdür.

\section{Odəbiyyat}

1. AFK-I, 2006: Azərbaycan folkloru külliyyatı, I cild. Nağıllar I kitab / Tərtib edənlər H.İsmayılov və O.Oliyev. Bakı: Səda: 2006, 400 s.

2. AFK-VII, 2008: Azərbaycan folkloru külliyyatı, VII cild. Nağıllar VII kitab/Tərtib edənlər H.İsmayılov və O.Đliyev. Bakı: Nurlan, 2008, 400 s.

3. AFK-IX, 2008: Azərbaycan folkloru külliyyatı, IX cild. Nağıllar IX kitab/Tərtib edənlər H.İsmayılov və O.Đliyev. Bakı: Nurlan, 2008, $400 \mathrm{~s}$.

4. Hacıyeva... 2009: Hacıyeva M., Rıhtım M. Folklor və təsəvvüf ədəbiyyatı sözlüyü. Bakı: Nurlan, 2009, $130 \mathrm{~s}$.

5. AFK-VIII, 2008: Azərbaycan folkloru külliyyat1, VIII cild. Nağıllar VIII kitab/Tərtib edənlər H.İsmayılov və O.Đliyev. Bakı: Nurlan, 2008, 400 s.

6. AFK-III, 2006: Azərbaycan folkloru külliyyatı, III cild. Nağıllar III kitab/Tərtib edənlər H.İsmayılov və O.Oliyev. Bakı: Səda: 2006, $400 \mathrm{~s}$.

7. Rüstəmzadə... 2013: Rüstəmzadə İ. Azərbaycan nağıllarının süjet göstəricisi (Aarne-Tompson sistemi əsasında). Bakı: Elm və təhsil, 2013, 368 s. 
Sahilə Osgər q1zı Abbasova

Naxçıvan Dövlət Universiteti doktorant

sahileli.uni@gmail.com

\section{I-IV SIINIFLOR ÜZRӘ AZЭRBAYCAN DILINDDON FOLKLOR MATERİALLARI ETNODIDAKTIK TəRBIYYə VASITOSİ KIMI}

Açar sözlor: təlim va tərbiya, metodik vasait, asas mətnlor, folklor materialları, nağıllar, təmsillar, tapmacalar, çalışmalar sistemi, etnopedoqoji tərbiya, nəticə

\section{Folklore in Azerbaijani language for I-IV grades materials as a means of ethnodidactic education \\ Summery}

The main texts in the "Azerbaijani language" compiled on the basis of folklore materials such as textbooks of primary school include tales, epics, representations, etc.. In these textbooks, proverbs from riddles are also enriched with parables, sayings, and words of advice. Observations beginning in the first grade showed the breadth of such opportunities and, most importantly, their educational value. In the article, we aim to show the breadth of didactic opportunities of the first grade. We continue our research on other classes and bring all this to the attention of our teachers and methodologists.

Key words: training and education, methodical aids, main texts, folklore materials, tales, fables, riddles, system of exercises, ethnopedagogical education, result

\section{Giriş}

Kurikulum metodologiyası əsasında yaradılmış ibtidai siniflər üzrə "Azərbaycan dili" dərsliklərində folklor materialları geniş yer tutur. Belə materiallar ənənəvi dərsliklərdə də olmuşdur. Lakin o zamanlar belə materiallar "Oxu" dərsliklərində verilərdi. 2008-ci ilə qədərki "Oxu" dərslikləri ilə müqayisədə indiki "Azərbaycan dili" dərsliklərində bu cür materiallar say etibarı ilə daha çoxdur. İndi müasir dərsliklərlə yanaşı, onlara dair hazırlanmış metodik vəsaitlərdə də (MMV) folklor materialları verilir. Bunlar daha çox nağıllar, dastanlar, rəvayətlər, atalar sözləri, tapmacalar, nəsihətlər, laylalar, əzizləmələr, habelə digər növdən və janrdan ibarət şifahi xalq ədəbiyyatı nümunələrindən ibarət parçalar, mətnlər və s. ibarətdir. Belə materiallar həm dinləmə-anlama və danışma, həm oxu, həm yazı və həm də dil qaydalarına dair sadə, aydın və asan cümlələr kimi dərslikləri bəzəyir.

Birinci sinif şagirdi üçün keçi balalarının, qaranquşların, quzuların, ayıların, canavarın və s. insan kimi danışması, əlbəttə, maraq doğurmaya bilməz. Heyvanların həyatı ilə insanların həyatının qarşılaşdırılması, atların şahə qalxması, insanlara alışması, "igidin qardaşı" olması uşaqda instiktiv olaraq bu inamı yaradır. Heyvanlarla dostluq onlarla qurulan insanı təmas uşaqları daha çox heyran edir. Uşaqlar itə, ata, göyərçinə etibarlı canlı kimi və hətta müqəddəs varlıq kimi yanaşırlar. Simurq quşunu görməslər belə, ona fəhmlə də olsa, böyüklər kimi onlar da inanırlar.

Dahi Nizami məhz elə bu məsələdən bəhs edərkən yazmışdır:

"Möcüzə göstərən rəssama bax sən,

Simurq şəkli çəkir quşu görmədən".

Müasir ibtidai sinif dərsliklərində belə cəlbedici uşaqları heyrətə salan folklor materialları birinci sinifdən başlayaraq təlim işinə xoş ovqat gətirir. Bu baxımdan dərsliklərimizi təhlil etsək, aşağıdakı kimi xoş bir mənzərə yaranar və folklor materiallarının təlimləndirici, etnotərbiyəedici və inkişafetdirici rolundan danışmaq olar.

Birinci sinif "Azərbaycan dili” dərsliyinə (1) yazılmış metodik vəsaitdə (2) dördüncü dərsdən başlayaraq (2, s.29) folklor materiallarından tərtibçi metodistlər müxtəlif məqsədlərlə istifadə etmişlər. Bunların yığcam siyahısını tərtib etsək, qarşımızda belə bir mənzərə açılar: 
1.Dördüncü dərs. "Turp”, (2, s.29)

2.Doqquzuncu dərs. "Meşədə”, (2, s.36)

3.İyirmi doqquzuncu dərs. "Tülkü və leylək", (2, s.66)

4.Q1rxınc1 dərs. "Göy göldə", (2, s.84)

5.Q1rx birinci dərs. Motivasiya,(2, s.88)

6.Q1rx ikinci dərs. (2, s.91)

7.Q1rx dördüncü dərs. (2, s.92)

8.Q1rx beşinci dərs. (2, s.94)

9.Q1rx yeddinci dərs. (2, s.96-97)

10. Yetmiş ikinci dərs. (2, s.127)

11. Yetmiş üçüncü dərs. (2, s. 129)

12. Yetmiş dördüncü dərs, (2, s.130)

13. Yetmiş beşinci dərs, (2, s.131)

14. Yetmiş yeddinci dərs, (2, s. 133)

15. Yetmiş səkkizinci dərs, (2, s.134)

16. Yetmiş doqquzuncu dərs, $(2, \mathrm{~s} .135)$

17. Səksən ikinci dərs, (2, s.138)

18. Səksən üçüncü dərs,(2, s.139)

19. Səksən dördüncü dərs, (2, s.140)

20. Səksən beşinci dərs, (2, s.141)

21. Səksən altınc1 dərs, (2, s.142)

22. Səksən yeddinci dərs, (2, s.143)

23. Səksən səkkizinci dərs, (2, s.144)

24. Səksən doqquzuncu dərs, (2, s.145)

25. Doğsanıncı dərs dərs, (2, s.146-147)

26. Doğsan birinci dərs, (2, s.148)

27. Doğsan ikinci dərs, keçi və tülki”, (2, s.149)

28. Yüz birinci dərs, (2, s.104)

29. Yüz beşinci dərs, (2, s.105)

30. Yüz altıncı dərs, (2, s.166) və s.

Biz burada folklor materialları olan səhifələri məqsədlə əlaqədar seçmə yolla və ya ixtisarla verdik. Məqsəd ondan ibarətdir ki, folklor materiallarından müxtəlif didaktik sitiuasiyalarda və yaxud da məqamlarda istifadə edilir. Onlardan motivasiya, nəticə, dinləmə, inteqrasiya məqsədi ilə və bəzilərindən də ümumiləşdirici suallar kimi istifadə edilir. Metodik vəsaitdə 17-23, 31-40, 44-74, 89 və digər səhifələrdəki folklor nümunələrinin əksəriyyəti motivasiya məqsədi daşıyır. Həmin nümunələrdən bəzilərini aşağıda qeyd etməyi məqsədə müvafiq hesab etdik:

1. Oyun zamanı istifadə edilənlər

“- Әl üstə kimin əli? -

Qaragözlü ceyranın.

- Götürün, götürün vurağın

- Ol üstə kimin əli?

- Kələm yeyən dovşanın.

- Götürün, götürün vurağın”!

- "Әl üstə kimin əli?

- Mənim bacım Aydanın

- Tapd1, buraxin, dursun!

- İndi Aydan buyursun!"

Yeri gəlmişkən, onu da nəzərə almalıyıq ki, bu oyunun mahiyyəti haqqında müəllim məlumat verməlidir. Tarixi çox qədim olan belə oyunların sözlərinə bəzən müəllimlər əlavə və dəyişikliklər də edirlər. Belə olanda materiallar folklor motivli olan müəllifli etnodidaktik mətn sayılır. 
2. Metodik vəsaitin 48-ci səhifəsindəki tapmaca folklor materialı sayılır.

"Bağlarda taqq1ldar,

Meşədə şaqq1ldar" (Balta).

"Qanadı var uça bilməz,

Quru yerdə qaça bilməz" (balıq).

Təbii ki, bu tapmacadan "b" hərfini öyrətmək üçün istifadə olunur.

3. "Așpaz Abbas aş asmış,

Asmışsa da, az asmış".

Bu yanıltmacdan "ş" səsinin öyrənilməsində motivasiya vasitəsi kimi istifadə edilir.

4. Sanama motivli bu mətnə baxaq:

"Üçü bizə yağıdır,

Üçü cənnət bağıdır,

Üçü yığıb gətirir,

Üçü vurub dağıdır".

Bu tapmacada əsas məqsəd "ü" səsi və hərfinin öyrədilməsidir.

5. 39-cu dərsdə çox ibarətamiz deyim var: biz həmin deyimi öyrətməyi və ya onun mənasını şagirdlərə aşılamağı müəllimin nəzərinə çatdırırıq: Görün necə etnopedoqoji tərbiyə üçün zəruri olan bir folklor nümunəsidir:

Özü özünü

Öyərsə kimsə,

Ömrümdə onun

Ad1 yüksəlməz (2, s.82).

“Ö hərfini öyrənmək məqsədi ilə işlənən bu deyim və ya hikmət folklorun tərbiyəediciliyinə ən gözəl sübutdur. Bunu pedaqoqlar təlim vasitəsi ilə tərbiyə nəzəriyyəsinə ən yaxş1, ən tutarlı misal kimi göstərirlər.

6. Dərsliyin 84-cü səhifəsindən:

"O nədir ki,

Hər gözünü yumanda dünya zülmət görünür”.

“O, gözünü açanda aləm nura bürünür?” (Günəş).

Yaxud:

"İki fanar:

Gündüz yanar,

Gecə sönər" (Göz).

Yaxud da:

"Meşədir, çəməndir, oylağım mənim,

Özümdən yekədir papağım mənim" (Göbələk).

Bütün bunların sayını istənilən qədər artırmaq olar. Lakin biz məqsədlə əlaqədar həmin göstərilənlərlə kifayətlənirik.

Dərslikdə olduğu kimi, metodik vəsaitdə də bir neçə nağıl, əfsanə, təmsilin əsas mətn kimi öyrədilməsi nəzərdə tutulur və onların inteqrasiya dairəsində həm təlim və həm də tərbiyə məqsədləri diqqəti cəlb edir. Bunlar konkret olaraq hansılardır? "Turp" (1, s.30), "Meşədə" (1, s. 37), "Novruz bayramı" (1, s.124), "Zolaqlı burunduk" (1, s.129), "Canavar məsləhəti”"(1, s.130), "Nə üçün pişik yeməkdən sonra yuyunur" (1, s.133), "İtlə insan necə dost oldular" (1, s.134), "Niyə ayın paltar1 yoxdur" (1, s.138), “Ay1 və kəndli”, (1, s.139) "Cırnatma" (1, s.143), “Ördək balalar1 və cücə”, (1, s.144), "Ağac-hər dərdə əlac" (1, s.145), "Nəzakətli dovşan”"(1, s.147), "Ayı və günəş" (1, s.148), "Kələm yarpağı" (1, s.161), “Ayoqa"(1, s.165), “Kimin əlləri daha gözəldir” (1, s.166) və $\mathrm{s}$.

Qeyd olunan hər bir mövzunun məzmunundan müvafiq olaraq ya atalar sözləri, ya nəsihət, ya da məsləhət və s. ç1xır. Eyni zamanda çalışmaların icra şərtləri də müəyyən məsələləri şagirdlərin diqqətinə çatdırır, yaxud da onların müəyyən məsələyə münasibət bildirməsini tələb edir. Misal üçün, "Nəzakətli dovşan " adlı Meksika nağılının tərbiyəedici imkanları bir çox tələblərdə olunur. 
Belə ki, burada fəndaxili əlaqəyə uyğun olaraq müvafiq nitq etiketləri əhatə olunmaqla şagirdlərə nəzakət qaydalarına dair tapşırıqlar verilir və həmin tapşırıqlar divardan da asılmış olur. Məsələn:

1.Gəlin biz özümüz də nəzakətli olaq ki, başqaları bizimlə mehriban davransınlar.

2.Biz özümüz qayğıkeş olsaq, başqaları da bizə qayğı göstərərlər.

3.Bizə xeyirxah olanlara biz də xeyirxah olaq.

4.Heç yerdə narahatlıq yaratmayaq, həmişə icazə ilə danışmağa, yaxud getməyə və yaxud da içəri girməyə çalışaq.

5.Biz bir yerə gedərkən haraya getdiyimizi, nə vaxt gələcəyimizi də söyləməyi unutmayaq.

6.Salamlaşmaq, hal əhval soruşmaq, ayrılarkən sağollaşmağı unutmamalıyıq. Bu barədə nəzm dili ilə belə yazılıb:

Salamlaşmaq, hal soruşmaq əhval bilmək də,

Oziz dostlar məclisində deyib gülmək də,

Dədə-baba qaydasıdır, gözəl adətdir,

Düz ilqar da insanlığa bir səadətdir (Səməd Vurğun).

7. Danışanda səsimizə, sözümüzə fikir verək, harada, kimlə, necə hərəkət edəcəyimizi düşünək və s. (2, s.147).

\section{Notica}

Bütün bunlardan göründüyü kimi, təlimin tərbiyəedici imkanlarını nəzərə almaq gözəl ənənədir. $\mathrm{Bu}$ ənənəni yaşatmaq olduqca aktualdır. Kurikulum fəlsəfəsində tərbiyənin nüvə redaktoru hesab olunması bununla əlaqədardır. Folklorla müasirliyin inteqrasiyasının nəticəsi özünü şagirdlərə tarixi təcrübə və müasirlik tərbiyəsinin aşılanmasında göstərir. Məhz elə ona görə də pedaqoqikamız tərbiyəedici didaktika sisteminin pərdələrində köklənmişdir. Bu dediklərimiz birinci sinifdə sayca 30-dan çox seçdiyimiz folklor materiallarının yalnız birindən hasil edilən nəticələrdir. Halbuki I-IV siniflərdə folklor materiallarının sayı, təxminən, 120-dən də çoxdur. Onların hər birinin təlimi etnodidaktika və müasirlik telləri ilə möhkəm-möhkəm bağlanmalıdır. Folklorla tərbiyə valideynlərin ədəb-ərkanla bağlı nəsihətlərindən başlanırsa, məktəbdə sistemlə aşılanarsa, deməli, yaxşı nəticələri olacağına dərin inam yaradır. "Təhsil millətin gələciyidir". O, yəni təhsil müasir insan tərbiyə edir. Bu da bizim son nəticəmizdir.

\section{Odəbiyyat}

1. Rafiq İsmay1lov, Solmaz Abdullayeva, Gülşən Orucova, Dilruba Cəfərova. Ümumtəhsil məktəblərinin 1-ci sinfi üçün “Azərbaycan dili” (tədris dili kimi) fənni üzrə dərslik. Altun kitab, Bak1, 2018, 160 səh.

2. Solmaz Abdullayeva, Rafiq İsmayılov, Dilruba Cəfərova, Gülşən Orucova. Ümumtəhsil məktəblərinin 1-ci sinfi üçün "Azərbaycan dili” (tədris dili kimi) fənni üzrə müəllim üçün metodik vəsait. Altun kitab, Bakı, 2018, 168 səh. 


\section{AZəRBAYCAN DILLÇILIYYINDə FRAZEOQRAFIYA}

Açar sözlor: frazeoloji vahid, frazeoloji lüğðt, frazeoloji semantika

\section{Phraseography in Azerbaijani linguistics \\ Summary}

In this article, existing phraseological and general dictionaries are analyzed in terms of descriptive phraseological units. Research shows that in most cases, phraseological semantics is not disclosed. That is, phraseological units are semantized at the level of lexical units and free word combinations. The second obvious shortcoming is the presentation of fixed word combinations in dictionaries as a phraseological unit. This fact proves that fixed word combinations are still indistinguishable from phraseological units, both theoretically and practically. Due to the fact that the essence of the phrases called "phraseological combinations" by Academician VV Vinogradov is not explained in Azerbaijani linguistics, fixed phrases are given as phraseological units in general explanatory and special phraseological dictionaries published in Azerbaijan today. In general, the analysis shows that there is a serious need to develop a new large-scale phraseological dictionary in Azerbaijan.

Key words: phraseological unit, phraseological dictionary, phraseological semantics

Frazeoqrafiya - yazının elə növüdür ki, bir işarə kontekstdə cümlənin hissəsinə, yaxud cümləyə bərabər olur. Bizə məlum məxəzlərdən öyrənirik ki, Azərbaycan dilçiliyində frazeoqrafiya sistemində PFK-ların etimoloji səpgidə ciddi tədqiqatları olduqca azdır, paremiologiya-etimoloji lüğətlər isə (kiçikhəcmli frazeoloji-etimologiya lüğətlərini nəzərə almasaq) yox dərəcəsindədir.

Frazeoqrafiya XX əsrdə hələ tam araşdırılmamışdır və çox vaxt leksik məna frazeoloji mənadan fərqləndirilməyib.

Azərbaycan leksikoqrafiyası tarixində ilk irihəcmli üçdilli frazeoloji lüğət professor Nigar Vəliyeva tərəfindən tərtib olunmuş “Azərbaycanca-ingiliscə-rusca frazeoloji lüğət” dir. Lüğət hər üç dildə olan frazeoloji birləşmələri əhatə etməsi baxımından xüsusi önəm kəsb edir və doqquz mindən artıq birləşməni əhatə edir. Kitabın baş redaktoru AMEA-nın həqiqi üzvü, professor Ağamusa Axundov, ön sözün müəllifi isə professor Nizami Cəfərovdur.

Dilçi alim, pofessor Qulu Məhərrəmlinin və filologiya üzrə fəlsəfə doktoru Rafiq İsmayılovun birlikdə hazırladı̆̆ı yeni və mükəmməl “Azərbaycan dilinin frazeologiya lüğəti”ni yüksək poliqrafik tərtibatla nəşr etmişdir. Dilçi alim daha sonra qeyd etmişdir ki, lüğətçiliyimizin tarixi uzun olsa da, söz birləşmələri sözlükləri yaradılmasına sonrakı dövrlərdə təşəbbüslər göstərilib. Bu sahədə müəyyən uğurların qazanılması, dilimizin frazeoloji sisteminin çağdaş elmi təsnifatı mükəmməl lüğətin də yaradılmasını tələb edirdi. Bu baxımdan dilçiliyimiz ilk dəfədir ki, aydın tərtib prinsipləri və elmi cəhətdən dürüst əsaslandırılmış strukturu ilə fərqlənən zəngin sözlük əldə etmişdir. 7 minə yaxın söz birləşməsinin izahını verən lüğətin ən yaxşı cəhəti odur ki, burada frazeologiyanın hüdudları dəqiq müəyyənləşdirilmiş, sabit söz birləşmələri, mürəkkəb sözlər, tərkibi feillər, məcazlar, obrazlı ifadələrlə frazeologiya arasında münasibətlər nəzərə alınmışdır.

Çox sayda təsnifatın olması, bunların heç biri səhvlərin olmamasına $100 \%$ zəmanət verməməsi ilə əlaqədardır. Buna görə də, frazeologiyanın növünü dəqiq müəyyənləşdirə bilmirsinizsə, hans1 lüğətlərdə işarə tapa biləcəyinizi bilməyə dəyər. Bu tip bütün lüğətlər çoxdilli və birdilli bölünür. Aşağıda bu tip ən məşhur kitablar var, bunlarda rus dilində ən çox yayılmış sabit ifadələrin nümunələrini tapa bilərsiniz. 
Birdilli: E.B1strovoyun "Təhsil frazeoloji lüğəti”; V.Kuzmichin "Yanan fel - xalq ifadələrinin lüğətidir"; A.Fedoseyevin "Rus dilinin frazeoloji lüğəti"; İ.Fedoseyevin "Rus ədəbi dilinin frazeoloji lüğəti" və M.Mişelsonun "Böyük izahlı frazeoloji lüğət".

Çoxdilli: A.Kuninin "Böyük İngilis-Rus frazeoloji lüğəti” (iyirmi min frazeoloji növbə), Yu.Lukşinin "Böyük Polşa-Rus, Rus-Polşa Frazeoloji Lüğəti” və Sofiya Lyubenskayanın İdiomlərin Təsadüfi Evi Rus-İngilis lüğəti.

Bəlkə də bəzən hansı frazeoloji vahidin mənsub olduğunu dərhal ayırd etmək çətin olduğunu öyrəndikdən sonra bu mövzu olduqca mürəkkəb görünə bilər. Ancaq şeytan boyanmış olduğu qədər dəhşətli deyil. Digər frazeoloji vahidlər arasında sözlərin frazeoloji birləşməsini düzgün tapmaq bacarığını inkişaf etdirməyin əsas yolu mütəmadi məşq etməkdir. Xarici dillərdə isə-bu kimi ifadələrin meydana gəlməsi tarixini öyrənmək və əzbərləmək. Bu, gələcəkdə yalnız yöndəmsiz vəziyyətlərə girməməyinizə kömək edəcək, eyni zamanda nitqi çox gözəl və təxəyyüllü hala gətirəcəkdir.

Dünyanın bütün dilləri üçün ortaq bir həqiqət yaradılışdır deyimlər (gr. idioma - bir növ ifadə), və ya ifadələr (gr. phrasis - ifadə, nitq dövriyyəsi) - sözlərin sabit mürəkkəb birləşmələri. Bu cür vahidlərin yaradılması söz birləşmələrinin tez-tez təkrarlanması ilə əlaqədardır. Frazeoloji və ya idioma. Beləliklə, 1. Davamlı nitq elmi. 2. Dildə fond deyim və ya ifadələr.

Davamlı nitq növbələri sözlərin sərbəst birləşməsinə qarşıdır. Pulsuz söz birləşmələri fərqlənir ki, bunlardakı sözlər öz mənalarına malikdir və buna görə də dilin bir çox digər sözləri ilə birləşdirilə bilər. Məsələn, söz itiləmək müxtəlif sözlərlə birləşdirilə bilər: qayçı, bıçaq, mişar, qələm və bənzəri; söz yemək birləşmələrində də pulsuzdur, məsələn, dondurma yeyin, çörək, nahar və $\mathrm{s}$.

Sərbəst ifadələrdə fərdi sözlərin mənaları əlavə kimi görünür, natiq tərəfindən "ümumiləşdirilir" və ifadələrin ümumi mənası sözlərin birləşməsindəki mənalardan aydın görünür. Yerləşdirmə qayçı itiləyin, dondurma yeyin birləşməyə daxil olan sözlərlə müəyyən edilən bir dəyəri var. $\mathrm{Bu}$ vəziyyətdə, formanın ayrılması ilə məzmunun, mənanın ayrılması arasında bir uyğunluq da mövcuddur, yəni bu pulsuz birləşmələrin hər biri iki vahiddən (forma baxımından) və iki vahiddən (məna baxımından) ibarətdir.

Sözlərin sərbəst birləşməsi, bir qayda olaraq, danışma prosesində, fikir, hiss və əhval-ruhiyyəni ifadə etməkdə ehtiyaclarına uyğun olaraq edilir.

Mövcud frazeoloji lüğətləri həcminə görə bir-birindən çox fərqlənirlər: mindən iyirmi beş minə qədər və daha çox frazeoloji vahidləri əhatə edən frazeoloji lüğətləri məlumdur. Məsələn, "Azərbaycanca-ingiliscə, ingiliscə-Azərbaycanca müxtəsər frazeoloji lüğət”, (tərtib edənləri: X.Ohmədova, İ.Rəhimov), 1962, “Англо-русский фразеологический словарь”, 25000, 1967 , "Rusca-Azərbaycanca frazeologiya lüğəti”, (tərtib edən: M.T.Tağıyev), 1974, "Azərbaycanca rusca frazeologiya lüğəti", (tərtib edən: Orucov Ә.Ә.), 1976, "Farsca-Azərbaycanca müxtəsər idiomatik ifadələr lüğəti", (tərtib edənləri: Ә.M.Şəfai, F.İ.Zülfüqarova), 1978, "Müxtəsər Azərbaycanca - rusca və rusca - Azərbaycanca atalar sözü lüğəti”, (tərtib edənləri: B.Tahirbəyov, Ә.Hüseynzadə), 1983, “Англо-русский фразеологический словарь”, (tərtib edən: A.V.Kunin), 12 1984, "Russian - English Dictionary of Winged Words", 1900 words approx, (tərtib edənləri: İ.A.Uolş, V.P.Berkov), 1984, “Краткий русско-английский фразеологический словарь”, 1000, (tərtib edənləri: V.V.Qureviç, J.A.Dozorets), 1988, "Русско-английский словарь пословиц и поговорок", (tərtib edənləri: S.S.Kuzmin, N.L.Şadrin), 1989, "English - Russian dictionary of verbal collocations", (tərtib edən: R.S.Qinzburq), 1996, "Almanca - azərbaycanca - rusca frazeoloji lüğəti”, (tərtib edənləri: S.Abdullayev, N.Seyidəliyev), 2004.

Müxtəlif sistemli dillərdə frazeoloji vahidlərin liqvistik təhlili zamanı funksional - kontekstual xüsusiyyətlərini tədqiq edərkən, belə nəticəyə gəldik ki, onlar şifahi nitqdə və yazılı kontekstdə, ümumxalq danışıq dilində, bədii ədəbiyyatda və publisistik yazılarda işlənir, qəzet və jurnal kütləvi məlumat vasitəsi kimi nitq fəaliyyətində mühüm yerlərdən birini tutur və digər mətn növlərindən bəzi xüsusiyyətlərinə görə fərqlənir. Ümumi həcmdə çap məhsullarının böyük bir hissəsi qəzet və jurnalların payına düşür. Yazılı nitqin mühüm bir hissəsi də qəzet mətnlərində əks olunur. Qəzet 
təkcə kütləvi oxucuya deyil, həm də kütləvi müəllifə malikdir. Bunun nəticəsində qəzet dilin daşıyıcısı olan kollektivin dilinə güclü normalaşdırıcı təsir göstərir, dildə müəyyən normanın sabitləşməsinə imkan yaradır. Bundan başqa, müəlliflər öz dillərini müəyyən dərəcədə oxucuların gündəlik danışıq dilinə yaxınlaşdırmağa çalışaraq, tez-tez normadan uzaqlaşır, dil vahidlərinin nitqdə qeyri-normativ, yeni istifadə formalarından faydalanırlar. Qəzet bədii mətnlərdə və normativ sorğu kitablarında qeyd olunmağa imkan tapmayan dil faktlarını və dildə baş verən bütün dəyişiklikləri, demək olar ki, ani qeydə almağa imkan verir. Beləliklə, qəzet mətnləri ən yeni dil məlumatları mənbəyi ən yeni dil məlumatları mənbəyi rolunu oynayır. Qeyd etməliyik ki, ancaq frazeoloji vahidlərin siyahısı tədqiq olunan dilin bütün zənginliyini saxlamağına təminat verə bilər.Doğrudan da, bəzi dilçilər qeyd etdiyi kimi, indiyə qədər dilçilikdə "lüğət vahidi" anlayış1 dəqiq müəyyənləşdirilməmişdir. Məsələn, türk dillərində sözlərin nitq hissələrinə görə təsnifi və söz-formaların hər hansı bir leksemə aid edilməsi bir çox hallarda tamamilə mübahisəli hesab olunur. Mürəkkəb feilləri quruluşlarına görə oxşar söz birləşmələrindən ayırmaq üçün hamı tərəfindən qəbul olunmuş ümumi qaydanın olmaması ilə əlaqədar göstərilən konstruksiyalar komponentlər üzrə müstəqil yazılmış oldu. İlk təcrübə kimi, üçdilli frazeoloji lüğətin əhəmiyyəti çox böyükdür. Onun çapı bu sahədə aparılacaq araşdırmaların daha da genişlənməsi üçün təkan ola bilər. Belə bir lüğətin tərtibi olduqca çətin və mürəkkəb bir iş idi. Bir çox görkəmli dilçilər belə tədqiqatların perspektivinə inanır, bu sahədə aparılacaq işlərə dəstək verir, süni maneələr yaratmırlar. XX əsrin axırında maşın tərcüməsi dilin mühəndis dilçiliyi metodları ilə tədqiqi istiqamətində bir çox uğurlar qazanıldı. Lüğətin elmi redaktoru Azərbaycan Milli Elmlər Akademiyasının müxbir üzvi, filologiya elmlər doktoru, professor Nizami Qulu oğlu Cəfərovdur. $\mathrm{Bu}$ lüğət ingilis və rus dillərini öyrənənlərə, filoloq, diplomat və tərcüməçilərə, jurnalist və iş adamlarına, mədəniyyət işçilərinə çətinlik törədə bilən dil hadisələrini elmi-praktik şəkildə müəyyənləşdirmək, bununla da onları müəyyən şəraitdə düşdükləri dil çətinliyindən qurtarmağa kömək məqsədilə yazılmışdır. Müxtəlif sistemli dillərin materialları əsasında yaradılmış bu lüğətin dilçiliyin frazeologiya sahəsinə maraq dairəsinin formalaşmasında rolu böyükdir. Bu lüğət bədii dilin normalaşdırılması, eləcə də nitq mədəniyyəti məsələləri ilə əlaqədar tədqiqatlarda da böyük əhəmiyyət kəsb edir. Tərtibçi lüğət haqqında rəy, təklif, arzu və tənqidi qeydlərini göndərəcək oxuculara qabaqcadan minnətdarlı̆̆ını bildirir.

Keçən əsrdə dövrün frazeoloji baxışlarına uyğun şəkildə iki frazeoloji lüğət hazırlanmışdır. Olbəttə,ölkənin rəsmi dili rus dili olduğundan frazeologiya əksər hallarda rus dili materialı üzərində qurulduğundan bu lüğətlər ikidilli olmuşdur. Birincisi, M.T.Tağıyev tərəfindən hazırlanmış "Ruscaazərbaycanca frazeoloji lüğət", ikincisi isə Ә.Ә.Orucovun "Azərbaycanca-rusca frazeologiya lüğəti” dir.

Qeyd etmək lazımdır ki,hər iki lüğət frazeologiyanın Azərbaycanda dilçiliyin bir müstəqil sahəsi kimi təşəkkül tapmasında böyük rol oynamışdır. Eyni zamanda öz dövrünün səciyyəvi xüsusiyyətləri həmin lüğətlərin tərtibində özünü göstərirdi.

Göstərilən xüsusiyyət,ilk növbədə M.T.Tağıyevin hazırladığı "Rusca-azərbaycanca frazeoloji lüğət”də gözə çarpır.Lüğətin ilk nəşri 1964-cü ildə, ikinci nəşri 1974-cü ildə, üçüncü nəşri isə 2006ci ildə çapdan çıxmışdır.Müqəddimədə göstərilir ki, ikinici nəşr yenidən işlənmiş və təkmilləşdirilmişdir. $(1,10)$

Yuxarıda dəfələrlə qeyd olunduğu kimi M.T.Tağıyevin sovet elminə gətirdiyi ən böyük nailiyyət yaratdı̆̆ frazeoloji əhatə nəzəriyyəsi idi. Yalnız sovet elminə yox, prof. V.M.Mokiyenkonun qeyd etdiyi kimi, bu nəzəriyyə dünya elmində yüksək dəyərləndirilmişdir.

Olbəttə, bu nəzəriyyənin praktik əhəmiyyəti özünü frazeoqrafiya və dil tədrisində göstərmişdir.

Ümumi lüğətlərdə, “Azərbaycan dilinin izahlı lüğət”ində (4 cilddə), rusca-azərbaycanca və azərbaycanca-rusca lüğətlərdə də sərbəst söz birləşmələri, sabit söz birləşmələri və frazeoloji vahidlər əksər hallarda qarışdırılır, konfiqurasiya bütövlükdə verilmir. Misallar adətən göstərilmir.

Ә.Ә.Orucovun redaktəsi ilə 4 cilddə "Azərbaycan dilinin izahlı lüğəti " bu günə qədər ədəbi dilimizin ən dolğun leksikoqrafik mənbəsi olaraq qalır. Lüğətdə həm də frazeoloji vahidlər,atalar sözləri və zərbi məsəllər də öz əksini tapır. 
İzahlı lüğətdə əksər hallarda sabitlik kəmiyyət və keyfiyyət baxımından fərqləndirilmir. Məsələn, aba sözünə həsr olunmuş məqalədə abavü əcdad ifadəsi verilir. İfadənin mənası "atababalar, əcdad, nəsil, babalar" kimi izah olunur $(2,1,25)$ İfadə işarəsindən sonra verilir. Bildiyimiz kimi, bu işarədə sonra sabit söz birləşmələri verilir. Frazeoloji vahidlər isə işarəsindən sonra verilir.

Keçən əsrin ortalarına qədər Azərbaycan dilində frazeologiya sahəsində radikal tədqiqatlar aparılmamışdır.Bu sahənin ilk təşəbbüskarı M.Hüseynzadə "Müasir Azərbaycan dili" kitabında frazeologiya bəhsinə xüsusi yer ayırmışdır. (3) Milli dillərin frazeologiyası ilə məşğul olan alimlərdən professor Ә.Ө.Orucov (4), Q.K.Axunðyanov (5), M.İ.Adilov(6), A.Qurbanov (7), S.Cəfərov(8), M.T.Tağıyev (9), Ә.Dəmirçizadə (10) və başqalarını misal göstərmək olar. Frazeologiya sahəsində həmin alimlərin işlərinin çoxu ziddiyyətlidir.

Azərbaycan dilində leksikoqrafların səylərinə baxmayaraq tərtib edilən lüğətlərdə ziddiyyətli məqamlara rast gəlinir.Hansı tərkibin lüğətlərə daxil edilməsi lüğətlərdə öz əksini tapmamışdır. İstər professor Ә.Orucovun (11)Azərbaycanca-rusca frazeoloji lüğətinə, istərsə də M.T.Tağıyevin rusca-azərbaycanca frazeoloji lüğətinə daxil edilən frazeoloji vahidlər təsadüfi xarakter daşıyır, bunu müəlliflərin özləri də etiraf edirlər.

Frazeoloji lüğət tərtibində ən mühüm və mübahisəli məsələlərdən biri də atalar sözləri və zərbməsəllərin sözlüyə daxil edilməsidir. Azərbaycan dilçiliyində atalar sözü və zərb-məsələlərin yaranması, tarixi inkişaf yolu, leksik-semantik xüsusiyyətləri, frazeologiyaya münasibəti qlobal dairədə filologiya elmləri doktoru, professor Ziynət Olizadənin (12) "Azərbaycan atalar sözünün həyatı"adlı monoqrafiyasında ətraflı öz əksini tapmışdır.

F.H.Hüseynov da öz namizədlik dissertasiyasında atalar sözləri və zərb-məsəlləri fraziologiyanın obyekti hesab etmişdir. S.Cəfərov isə atalar sözləri və zərb-məsəlləri frazeologiya bəhsinə daxil etmiş və onların geniş üslubi imkanlara malik olduğunu qeyd etmişdir.

K.Y.Oliyev "Bədii ədəbiyyatda frazeologiyanın üslubi xüsusiyyətləri" adlı namizədlik dissertasiyasında atalar sözləri və zərb məsəlləri frazeologiyaya daxil edir.

N.R.Rəhimzadə "Azərbaycan dilində idiomatik ifadələr" adlı namizədlik dissertasiyasında frazeoloji vahidlərin bütün əlamətlərini sadaladıqdan sonra qeyd edir ki, Azərbaycan dilində frazeologiyanın öz səciyyəvi xüsusiyyətləri mövcuddur. Azərbaycan dilinin izahlı lüğətində verilən frazeoloji vahidlər haqqında (13) da öz fikrini söyləyərək lüğətdə frazeoloji vahidlərin yerləşdirilməsi məsələsini geniş dairədə şərh etmişdir ki, bu da demək olar ki, frazeoloji izahlı lüğətin tərtibi prinsipləri ilə uyğun gəlir.

Azərbaycan dilinin izahlı lüğətində atalar sözü və məsələlərin folklor materialı olduğuna görə izahlı lüğətin obyekti olmasa da onlardan bir qisminin lüğətə illüstrativ material kimi lüğətə daxil edilməsini müəllif kafi hesab edir. Atalar sözü və məsəllərin digər qismi frazeoloji vahidlərin leksik-qrammatik xüsusiyyətlərini daşıdığından lüğətə daxil olma hüququ qazanır.

Frazeoloji lüğətin niyyətlərindən biri də Azərbaycan dili tədqiqatçılarının əlinə eyni cəhətdən sistemləşdirilmiş müxtəlif hazır frazeoloji material verməkdən ibarətdir.

Frazeologiya lüğətinə bədii və publisistik əsərlərdən çıxarılan son dövrdə dərc edilmiş frazeoloji və izahlı frazeoloji lüğətlərdən alınan frazeoloji vahidlər də daxil edilməlidir.

\section{Odəbiyyat}

1. 1.(Тагиев .М.Т Русско-азербайджанский фразеологический словаръ Баку: Маариф, 1974, 246

2. Azərbaycan dilinin izahlı lüğəti. I cild. Bakı: Elm, 1966, 536 s; 4-cü cild Bakı: Elm,1987, 544 s)

3. Hüseynzadə M. Müasir Azərbaycan dili ADU nəşriyyatı B. 1954

4. Orucov Ә.Ә Azərbaycan dilinin izahlı lüğətinin nəzəri əsasları. Azərbaycan E.A nəşriyyatı B, 1965 (s.122)

5. 5.Ахунзянов Г.К О классификации фразеологических единиц татарского языка в сб. Вопросы фразеологии и составления фразеологических словарей. Б.1968

6. Adilov. M.İ Azərbaycan dilində təqlidi sözlər B. 1979

7. Qurbanov A.M Müasir Azərbaycan dili B.1967 
IV Respublika EImi Qaynaqlar Konfransının Materialları / 30 iyun 2021

8. Cəfərov S. Azərbaycan dilinin leksikası. ADU nəşriyyatı B. 1958 (s 32)

9. Тагиев М.Т. Глаголная фразеология современного русского языка. Из-во “Маариф”, Б., 1966. (c.251).

10. 10.Dəmirçizadə Ә.M. Azərbayan dilinin üslubiyyatı. B., 1962 (43)

11. 11.Orucov Ә.Ә. Azərbaycan dili izahlı lüğətinin nəzəri əsasları Azərbaycan. E.A nəşriyyatı B., 1965 (s.122)

12. 12.Đlizadə Z. Atalar sözünün həyatı. "Yazıçı” nəşriyyatı 1984 (244)

13. Rəhimzadə N.R Azərbaycan dilinin izahlı lüğətində frazeoloji vahidlər haqqında. Azərbaycan EA xəbərləri №2, 1981. (səh 94-95) 


\title{
VITTRAJ SəNӘTINDə MÜXTəLIF ÜSLUBLARDA ORNAMENTLəRIN İSTIFFADəSİ
}

\author{
Açar sözlar: başariyyat, handəsi, stiliza edilmiş, ritm, naxlş
}

\section{Utilization of ornaments in different styles of stained glass art Summary}

During the early development of mankind the main thing that unites ornaments in decorative-art is their diversity, aesthetic and emotional features. The decorativeness of stained glass art is explained by the ornamental motifs in composition. Ancient examples of stained glass art have been found in ancient cultures, as well as during the Middle ages. The design of modern interiors is perfectly complemented by the aestehetic appearance of artistic glass atributes in different styles. The most popular of these styles is known as traditional "classic" and "tiffany. İn stained glass art we often see stylized floral patterns with geometric patterns. In Islamic Art which avoids figurative images of complex geometric patterns has been used for centuries and these oriental motif ornaments are widespread in stained glass art worldwide. We can see the gorgeous rhythm of the patterns in architect structures, interiors, networked art today.

Key words: mankind, geometric, stylized, rhythm, pattern

\section{Giriş}

İncəsənət bəşəriyyətin mənəvi mədəniyyətinin tərkib hissəsi kimi ictimai şüur növüdür. İbidai dövrdə yaranan dekorativ incəsənətdə ornamental kompozisiyaların sadəliyi zaman keçdikcə onların rəngarəngliyi, estetik və emosional xüsusiyyətləri ilə birləşmişdir. Təsviri sənəti ornamentsiz təsəvvür etmək mümkün deyil. Tarix boyu ornamentlərin simvolik və semantik məna çalarları təsviri incəsənət, memarlıqda geniş istifadə olunmuşdur. Belə ki, qədim dövrlərdən insan ilk əşyanı daşdan, gildən və ağacdan düzəldərkən onların üzərində çəkdiyi naxış- təsvirlər dekorativ-tətbiqi sənətin başlanğıcı olmuşdur. Buna görə də, dekorativ-tətbiqi sənət - incəsənətin ən qədim növü sayılır. Mənbələrə əsaslanaraq deyə bilərik ki, qədim dövrlərdə ibtidai dövrün incəsənəti, dekorativ sənət çox maraql1 idi. Dekorativ-tətbiqi sənət bədii sənətin müxtəlif növlərini əhatə edir: döymə sənəti və zərgərlik, metal üzərində işləmələr, ağac, daş və sümük üzərində oyma naxış, xalçaçılıq, hörmə sənəti, ornamental toxuculuq və basma naxış, toxuma və bədii tikmələr və bir çox digərlərini göstərə bilərik. Dekorativ-tətbiqi incəsənətin inkişafına hər bir xalqın məişəti, yaşayışı, iqlim şəraiti təsir edirdi. Bu gün dekorativ-tətbiqi əşyalar sənaye üsulu ilə emal edilərək, müəyyən formada öz orijinal xüsusiyyətlərini saxlamışlar. (Mir-Bağırzadə, 2012: 56)

Monumental dekorativ-incəsənət dedikdə (mozaika, taxta üzərində naxış, vitraj və s. nəzərdə tutulur. Dekorativ tətbiqi sənət növü olan virtaj (fransız dilindən pəncərə) və şəffaf materialdan hazırlanmış ornamentli və ya süjetli kompozisiyadır. Vitraj rəngli şüşə mozaika, yaxud qurama kimi görünür. Vitraj sənətinin bədii nümunələrinə Roma, Bizans, Çin kimi qədim mədəniyyətlərdə, həmçinin orta əsrlərdə rast gəlinib. Qədim insan dünya haqqında təsəvvürlərini müəyyən işarələrlə ifadə edirdi: dairə-günəşi, üçbucaq - dağları, spiral - inkişafı, savstika- dinamikanı, kvadrat və romb isə torpaq mənasını bildirirdi. Artıq İtalyada intibah dövrünün ustaları qədim ənənələrdən istifadə edərək ağ daşlı binaları zəngin naxışlarla, çox rəngli mərmərdən, şüşədən və digər qiymətli daşlardan hazırlanmış çoxsaylı panellərlə bəzəyirdilər. Hal- hazırda istehsal texnikasından asılı olaraq bir neçə fərqli vitraj növləri mövcuddur: "tiffany", "fyuzing” və s. Vitraj sənətində bir çox üslubların mövcudluğu və inkişaf tarixi sənətşünaslar tərəfindən araşdırılır. Zaman keçdikcə bu üslublar fərqli ölkələrin və dövrlərin mədəniyyətlərini özündə əks etdirdi, yeni texnikaların ortaya çıxması istifadə olunan materialları təkmilləşdirməyə imkan verdi. Vitraj sənətində dekorativ 
əşȳalar təkcə rəssamın zövqünü və fantaziyasını göstərmir, o, həmçinin insanların mənəvi və maddi maraqlarını əks etdirir və ona görə incəsənətdə müəyyən tarixi dövrdə üslub vəhdətliyi (roman, qotika, məqrib üslubu) və ornamentlərin müxtəlifliyi əks olunurdu. (Mir-Bağırzadə, 2012: 60)

Klassik üslub. Bu üslubda mükəmməl simmetrik naxışlar isti, solğun rənglərlə tamamlanmışdır. Aydın xətləri, möhkəm, ağır mebelləri olan klassik interyerlər üçün uyğundur. Daha çox həndəsi naxışlarla stilizə edilmiş nəbati naxışların vəhdətini burada tez-tez görürük. Ornamentin yaxşı qurulmuş simmetrik kompozisiyası "klassik" üslub üçün xarakterikdir. Plastik formaların üfüqi və şaquli xətlərlə sintezi klassik vitraj kompozisiyasının üslubuna uyğundur. Min illik tarixi boyunca bu termin demək olar ki, yalnız kilsələrin və dini binaların pəncərələrində tətbiq edilmişdir. Müasir dövrdə "klassik" vitraj və ya "tiffany" texnologiyası vitraj sənətində geniş уаyılmışdır. (Мусинова, 2016: 4)

Qotika üslubu. Orta əsr Avropasında Katolik kilsələrinin tərzi belə adlanır. Nəhəng pəncərələrin və sünbül, tünd qırmızı, qırmızı, qızıl, yaşı1, mavi, bənövşəyi rəngli yüksək qüllələrin alatoranlığı ilə fərqlənir. Bu üslubda Orta əsr cəngavərləri, qalaları, istismarları, əjdahaları, tək buynuzlu atların həyatından mifoloji motivlərdən və ya səhnələrdən istifadə edilir. Gotik vitrajlar məkana sirr və ecazkarlıq bəxş edəcəkdir. Çox vaxt vitraj pəncərələrindəki incil səhnələri pəncərə örtüklərinin əsasını təşkil edən böyük çiçək və ya həndəsi bəzəklər çərçivəsi tamamlayırdı. Bunun parlaq nümunəsi Notre Dame de Paris Kafedralındakı məşhur güllərdir. Ləçəklərlə əlaqəli bir çox hissəyə, radiusa bölünən dəyirmi pəncərələr mürəkkəb çiçəklərə bənzəyir. Və hər bir seqmentdə müəyyən süjet səhnələrini əks etdirən vitraj kompozisiyaları var.

Modern üslub. Hər hansı bir daxili məkan üçün bəlkə də universal bir üslubdur. Bu üslub dalğavarı xətlər, bu və ya digər şəkildə dəniz dalğasının formasını təkrarlayan, lütfkarlıq, incəlik ilə xarakterizə olunur. Modern dövründə "tiffany" vitrajlarında bəzəklər kompozisiya baxımından, rəng baxımından, element sayı və sənət əsərindəki rolu baxımından xeyli mürəkkəbləşdi. Solğun, səssiz rənglər, orta tonlar, mavi-yaşıl rən tonlarından geniş istifadə olunur. Və indi əsərlərdəki əsas ideya ənənəvi stilizasiyada bitki və həndəsi məzmunu, qıvrımlar, "ampüller", çiçəklər və qönçələrdən ibarət kompleks birləşmələrdir. Bu üslubun əsas motivləri təbiətdən götürülmüş elementlərdir. Modern üslubu müasir texnologiya ilə yaxşı qarışır və yüksək texnoloji interyerlərlə vəhdət təşkil edir. "Art Nuvo" vitrajlarının dekorativ naxışları həmişə axıcı, dalğalavari formalara malik idi.

Misir üslubu. Qumlu qəhvəyi tonlarda olan zərif vitraj rəsmlərə aid edilir. Rəsm Misir heroqlifləri, tanrılarını, fironlarını və həyatlarından mənzərələri əks etdirir. $\mathrm{Bu}$ üslubun ornamentlərində antporomorf, zoomorf təsvirlərlə yanaşı əsas yeri disk şəkilli günəş simvolu, İsiada ilahəsinin təsviri geniş yer tutur.

Antik üslub. Rəsmlər qədim yunan mövzularıni əhatə edir və antik mozaikaya bənzədilir. Bu cür üslubda üç kiçik dekorativ detalın olması xarakterikdir. Üslub həndəsi, üfüqi və şaquli xətlərin ornamentlərdə harmoniyanın əks olunması ilə diqqəti çəkir. Minimalist interyer məkanları üçün daha uyğundur.

Bizans üslubu.Yalnız rəngli deyil, həm də şəffaf şüşə məmulatlarının istifadəsi ilə rəqlənən üslubdur. Bizans üslubunda şəffaf şüşə istifadəsi havada üzən bir şəkil illüziyası yaradır.

Avanqard üslub. Şəklin süjeti istənilən mövzunu əhatə edə bilər, ancaq müasir icra üsulları sayəsində həcm hissi verir. Təsvir çoxqatlı, üçölçülü detallarla, şəffaf və parlaq şüşələrdə nəzərəçarpan görünür. Belə interyerdəki vitrajlar güclü bir vurğu yaradır, buna görə bir stil seçərkən yanılmamaq vacibdir.

Hər bir xalqın özünəməxsus əşya forması, ornamenti, obraz və motivləri, simvolları, rəng uyğunluğu mövcuddur. Ornament həqiqi formaları yenidən canlandırır və son dərəcə ənənəvi motivlərlə şərh edilir. Yeni bədii ideallar daşıyan bir üslubun formalaşması prosesində tətbiqi sənətdə müxtəlif bəzək motivləri var. Ornamentin əsas təsnif xüsusiyyətləri onun mənşəyi, məqsədi və məzmunu ilə əlaqədardır. Ornament (naxış, nəqqaşlıq) - bəzək deməkdir. Ornamentin sərbəstliyi təkcə motivin seçilməsindən deyil, həm də təsvir motivinin stilizasiyası qaydasından ibarətdir. Motiv - ornamentin bir hissəsi, əsas elementidir. Ornament motivlərinə həndəsi, nəbati və heyvanlar 
aləminin elementləri daxildir. Ornament təsvir olunan motivlərin, formanın bir törəməsi və ona itaət edən bir quruluşun ritmik ardıcıllığı əsasında qurulmuşdur və müxtəlif növləri məlumdur. Həndəsi ornament - sadə həndəsi fiqurların (dairə, kvadrat, üçbucaq, düzbucaqlı və s.), nöqtə, ziqzaq, spiralvarı xətlərin ritmik təkrarlanmasından yaranır. Məlumdur ki, vitraj sənətinin ornamental kompozisiyalarında ən çox həndəsi naxışlardan istifadəsi edilir. İslam incəsənətində əsrlər boyu fiqurativ təsvirlər qadağan edilmiş, vitraj sənətində həndəsi ornamentlərin mükəmməl simmetriyaya əsaslanmış təsviri şərq aləmində geniş yayılmışdır. İslam incəsənətində mürəkkəb həndəsi ornamentlər mərkəzi simmetriyaya əsaslanır və "girih" adlandırılır. Xüsusən, şəbəkə sənətində əsas səciyyəvi xüsusiyyət bütöv bir dekorativ kompozisiyanı tərtib etmək məqsədilə şərq motivlərinin həndəsi naxışlarında öz əksini tapmasıdır. (3)

Animalistik ornamentlərdə naxışlar həqiqi və ya fantastik heyvanların stilizə edilmiş şəkillərini əhatə edir. Cüt quş təsvirləri dekorativ-tətbiqi incəsənət məmulatlarında ən qədim və sevilən motivdir. On geniş yayılmış animalistik ornamentlərdən. tovuzquşu və bülbül təsvirlərini göstərmək olar. Quşları adətən ya bir-biri ilə sevişən, ya da bir-birindən küsmüş şəkildə təsvir edirlər. Hər iki motiv xalq yaradıcılığında sevgi və ayrılığın simvolu kimi izah edilir. (3)

Nəbati (islimi) ornamentlər - təbiət formalarından ibarət olan naxışlardır. Nəbati naxış bir çox bitki növünün elementlərindən istifadə edir: yarpaqlar, çiçəklər, budaqlar, birlikdə və ya ayrıayrılıqda götürülmüşdür. Nəbati ornament element baxımından çox zəngin olması ilə yanaşı, müxtəlif variantlı kompleks motivlərə malikdir. Nəbati ornamentlər içərisində çox yayılmış kompozisiyalardan biri "İslimi”" adı ilə geniş şöhrət tapmış naxış ünsürüdür. İslimi - Yaxın Şərq, o cümlədən Azərbaycan dekorativ-tətbiqi sənətinin bütün sahələrində istifadə edilən yarpağa bənzər bir və ya iki qanadlı naxış elementidir. İslimi elementləri plastik formaları ilə vitraj nümunələrinin kompozisiyasına ritm və bədiilik qatır. (Mir-Bağırzadə, 2012: 58)

Kalliqrafik ornament plastik naxışların ritmində ifadəli mətnin ayrı-ayrı hərfləri və ya elementləri formasında olur. Orəb xəttatlı̆̆ının əsasında Qurani-Kərimin oxunması və yazılması vacib idi. Buna misal olaraq, Aya Sofya məscidinin vitraj pəncərələrinin ərəb yazılı kalliqrafik ornamentləri ilə möhtəşəm tərtibatını xüsusilə qeyd etmək lazımdır. Antropomorf ornamentlər motiv olaraq kişi və qadın obrazlarının stilizə edilmiş fiqurlarından və ya insan bədəninin ayrı hissələrindən istifadə edilərək yaradılan elmentləri birləşdirir. Məlumdur ki, insan təsvirlərinindən ibarət ornamentlər daha çox Avropa incəsənəti üçün aktualdır. Fantastik ornamentin əsas elementlərini mifik, fantastik varlıqlar təşkil edir. Məsələn, təkbuynuz, uçan at, əjdaha, müxtəlif fantastik quşlar, şirlər və s. Fantastik ornamentdən müxtəlif dövrlərdə daha çox nəqqaşlıqda, memarlıqda və s. sahələrdə istifadə olunub. (3)

\section{Notico}

Bədii yaradıcılıq və incəsənət materialları işlənmə texnikası üsulları ilə birləşəndə dekorativ sənət əsəri meydana gətirir. Utilitar olaraq, vitraj sənəti özündə mənəvi-mədəniyyətin elementlərini və milli ənənələri toplamışdır. Vitraj sənətinə aid nümunələr əşya mühitinin vacib bədii-məzmunlu elementləri-şüşə qablar, güllər üçün vazalar, dekorativ divar rəsmləri olan pannolardır. Onlarda texniki və estetik görünüş demək olar ki, bərabərdir və bir-birini ideal tamamlayır. Xalq dekorativtətbiqi sənətin sənətkarları nəsillərdən-nəsillərə bədii şüşə üzərində öz bacarıqlarını gənclərə ötürüblər. Uzun əsrlər boyu sənətkarlar memarlıq tikililərin ecazkar dekorunda, hətta qadınlar üçün zərgərlik əşyalarında belə bədii şüşənin imkanlarını göstərməyə nail olmuşdular. Vitraj sənəti özünün çoxəsrlik tarixi boyunca zəngin və özünəməxsus mədəniyyət yaratmışdır və onun yüksək inkişaf etmiş fəaliyyətini müxtəlif dövrlərin üslublarında müşahidə etmişik. Bədii məişət məmulatlarında istifadə edilən ornamentlər sadəcə estetik deyil, eyni zamanda məlumatlandırıcı funksiya daşıdımışıdır. Beləliklə, vitraj sənətindəki motivlər insan tərəfindən yaradılan maddi aləmin bədii tərtibatına xidmət edərək estetik görünüşünü tamamlayır. 
IV Respublika EImi Qaynaqlar Konfransının Materialları / 30 iyun 2021

1. Mir-Bağırzadə S. İncəsənət tarixi (Dərslik), Bakı, 2012, 117 səh. (http://anl.az/el/Kitab/2013/Azf-271360.pdf)

2. Мусинова А.С. Орнамент как основа декоративно-прикладного искусства. Евразийский научный журнал, 2016, №6 (http://journalpro.ru/articles/ornament-kak-osnova-dekorativnoprikladnogo-iskusstva/)

3. Батырова А.Т. Орнамент в декоративно-прикладном и оформительском искусстве. 2015 (https://otherreferats.allbest.ru/culture/00509817_0.html) 


\title{
Günay Forhad qızı Mustafayeva
}

Bak1 Dövlət Universiteti

magistrant

mustafayevagunay98@mail.ru

\section{COĞRAFIYA FONNINIIN TODRİSINDӘ MəLUMAT MÜBADILLəSI

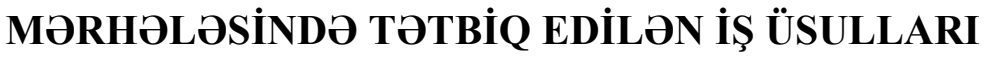

\author{
Açar sözlər: coğrafiya, məlumat mübadilasi, metod, iş üsulları, tədris prosesi
}

\section{Methods of work used in the exchange of information in the teaching of geography Summary}

Geography teaching methodology is one of the major disciplines of higher geographical education. As a branch of scientific knowledge, it defines the goals and objectives of geography as an academic subject, develops the content of school geography as a whole and its individual courses. He also explores the process of teaching geography, studies the forms of organizing the learning process, and develops educational equipment and methods for its use. Methods and techniques of teaching develops the most rational ways of teaching a student, his development, equips future specialists with scientifically grounded and practically proven methods of teaching and upbringing in relation to the content of various courses, age characteristics and the system of modern equipment of the pedagogical process.

Geographic excursions are one of the forms of organizing the educational process at school. On excursions, students meet with reality, see in the natural environment the manifestation of those connections, dependencies and patterns that they studied in class, acquire practical skills and abilities, learn to observe, notice in local geographic features such features, signs that they had previously paid no attention.

Key words: geography, information exchange, methods, working methods, teaching process

\section{Giriş}

Coğrafiya tədrisi metodikası ali coğrafi təhsilin əsas fənlərindən biridir. Elmi biliklərin bir qolu olaraq coğrafiyanın akademik bir fənn kimi məqsəd və vəzifələrini müəyyənləşdirir, bütövlükdə məktəb coğrafiyasının və onun ayrı-ayrı kurslarının məzmununu inkişaf etdirir, eyni zamanda coğrafiyanın tədris prosesini araşdırır, təlim prosesinin təşkili formalarını öyrənir, tədris avadanlı̆̆ 1 və istifadəsi metodlarını inkişaf etdirir, tədrisin metod və üsullarını araşdırır, bir şagirdin tədrisinin, onun inkişafının ən rasional yollarını inkişaf etdirir, gələcək mütəxəssisləri məzmunu ilə əlaqəli elmi əsaslandırılmış və praktik olaraq sübut olunmuş təlim və tərbiyə metodları ilə təchiz edir. Müxtəlif kurslar, yaş xüsusiyyətləri və pedaqoji prosesin müasir avadanlıq sistemi bu prosesdə nəzərə alınması gərəkən başlıca amillərdir. Coğrafiya tədrisi metodikası aşağıdakı suallara cavab verir (Понурова, 2016: 450).

1.niyə öyrədirsiniz?

2.nə öyrətmək lazımdır?

3.necə öyrətmək olar nə öyrətmək köməkliyi ilə?

4.məktəblilər necə öyrənir və inkişaf edir?

Keçmişin təcrübəsini tənqidi qiymətləndirməyə və müsbət cəhətlərindən istifadə etməyə imkan verən məktəb coğrafiyasının və metodoloji fikirlərin tarixi aspektdə inkişafının öyrənilməsi mühüm əhəmiyyət kəsb edir. Coğrafiya tədrisi metodikası ümumi coğrafiya tədrisi metodikası və xüsusi coğrafiya tədrisi metodikasına bölünür.

Coğrafiyanın tədrisinin ümumi metodologiyası coğrafiyanın tədrisi prosesini bütövlükdə araşdırır, təlim prosesinin qanunlarını müəyyənləşdirir, məqsəd və vəzifələri müəyyənləşdirir, məzmunu hazırlayır, formalarını, metodlarını, tədris vəsaitlərini müəуyənləşdirir (Левитес, 2018: 52). 
Coğrafiyanın tədrisinin özəl metodları, ümumi tədris metodikasının qanunauyğunluqlarına və nəticələrinə əsaslanaraq məktəb coğrafiyasında fərdi kursların tədrisinin xüsusiyyətlərini öyrənir, metodikanın fərdi məsələlərini (bacarıq və bacarıqların inkişafi, iqlimin öyrənilməsi metodologiyası və s.) araşdırır.

Coğrafiya fənninin tədrisində məlumat mübadiləsi mərhələsində tətbiq edilən iş üsulları tarixinə nəzər salsaq aydın olur ki, Sovet məktəbində coğrafiya fiziki və iqtisadi olaraq bölündü. Buna görə fiziki coğrafiya və iqtisadi coğrafiyanın tədrisi metodikaları inkişaf etdirildi. Fiziki və iqtisadi coğrafiya məsələlərinin öyrənilməsinin özünəməxsus xüsusiyyətləri var.

Qeyd etmək lazımdır ki, istənilən metodik tövsiyələr yaradıcı şəkildə istifadə olunmalıdır. Coğrafiyanın tədrisi metodikası coğrafi və pedaqoji bir sıra elmlərlə sıx bağlıdır. Metodologiya təhsilin məzmununu bir elm kimi coğrafiyadan götürür. Coğrafiya akademik bir fənn olaraq tədris, tərbiyə, inkişaf məqsədləri üçün seçilən və pedaqoji sistemə gətirilən coğrafiya elminin əsaslarıdır. Coğrafiyadan məktəb coğrafiyası bir elm olaraq təkcə təhsilin məzmununu götürmür, həm də coğrafi tədqiqat metodlarından tədris metodları kimi istifadə edir (kartoqrafik, müşahidə metodu, müqayisəli, statistik, sahə tədqiqat metodlarının elementləri). Məktəb coğrafiyası, əsasları məktəbdə geologiya, ekologiya, demoqrafiya, sosiologiya, iqtisadiyyat kimi müstəqil akademik fənlər kimi öyrənilməyən bir çox başqa sahələrin biliklərini də əhatə edir. Buna görə coğrafiyanın tədrisi metodikası bu elmlərlə əlaqələndirilir. Bunlardan didaktik prinsipləri rəhbər tutaraq təlimin məzmununu seçir.

Coğrafiya tədrisi metodikası özəl, fənn didaktikasıdır. Ümumi didaktika təhsilin məzmununu, ümumiyyətlə tədris, tərbiyə, inkişaf proseslərini araşdırır, təlim prosesinin qanunlarını müəyyənləşdirir, təhsilin məzmununun hədəflərini, seçim prinsiplərini müəyyənləşdirir. Didaktika konkret fənlərin öyrənilməsi prosesində məktəblilərin tədrisi, tərbiyəsi və inkişafının xüsusiyyətləri ilə əlaqəli deyil. Fərdi fənlərin öyrənilməsinin öz xüsusiyyətləri var: bəziləri nəzəri bilik əldə etməyə, digərləri bacarıq və s. inkişaf etdirməyə xidmət edir. Buna görə fərdi məktəb fənlərinin tədrisi prosesində ümumi təlim və tərbiyə nümunələrinin təzahürünün xüsusiyyətləri coğrafiya tədrisi metodikası da daxil olmaqla xüsusi metodika və ya xüsusi didaktika hesab olunur. Didaktika tədrisin ümumi nəzəriyyəsi olaraq metodologiya üçün ümumi metodoloji müddəaları (ümumi prinsiplər) inkişaf etdirir ki, bu metodologiya fənnin məzmunu və quruluşunun, tədrisinin forma və metodlarının inkişafinda rəhbər tutulur. Metodologiya öz növbəsində didaktikanı nəzəri təhlil və ümumiləşdirmə üçün materialla təmin edir (Жучкевич, 2013: 320).

Coğrafiyanın tədrisi yalnız mövzu ilə bağlı möhkəm bilik verməklə yanaşı, tələbələrin coğrafi material əsasında təhsili və inkişafına töhfə vermək və şagird şəxsiyyətinin formalaşmasına kömək etməkdir. Təhsil nəzəriyyəsi pedaqogika tərəfindən hazırlanmışdır. Buna görə təlim texnikası bununla sıx bağlıdır. Coğrafiya dərslərində təhsil məsələlərinin inkişafı pedaqogikanın müddəalarına əsaslanır. Hər hansı bir fənnin tədrisi tələbələrin yaş xüsusiyyətləri, fizioloji və psixoloji inkişafı nəzərə alınmadan mümkün deyil.

Tədqiq olunan material şagirdin səlahiyyətində olmalıdır, müəyyən bir maraq oyatmalıdır. Buna görə coğrafiyanın tədrisi metodlarının inkişafı böyük əhəmiyyətə malikdir. Məzmunun seçilməsində və coğrafiyanın tədrisi formaları və metodlarının seçilməsində müxtəlif yaş tələbələrinin psixofizioloji xüsusiyyətlərinə dair təhsil və inkişaf psixologiyasının məlumatları nəzərə alınır.

İstənilən fənnin tədrisində olduğu kimi coğrafiya fənninində tədrisində təhsil psixologiyasının xüsusi rolu məktəb coğrafiyası ilə əlaqəli öyrənmə motivlərinin, idrak maraqlarının inkişafına aiddir. Məktəb coğrafiyasının məzmununa dair nəzəri biliklərin artması ilə əlaqədar olaraq coğrafiyanın tədrisi metodları ilə məntiq arasındakı əlaqə gücləndirilir. Bunun üçün düşüncə formalarından birini də təmsil edən elmi konsepsiyalar proqramındakı açıq seçmə ilə əlaqədar xüsusi bir ehtiyac ortaya çıxdı. Məktəbin tapşırığı ilə "şagirdlərə öyrənməyi öyrətmək", onlara özözünə təlim və təhsil bacarıqlarını aşılamaq. Biliklərə yiyələnmək üçün şagirdlər məntiqi düşünmə metodlarından analiz, sintez, abstrakt, müqayisə, ümumiləşdirmə və s. istifadə edə bilməlidirlər. Hər hansı bir bilik sahəsi kimi coğrafiyanın tədrisi metodikası da birbaşa təsir göstərən təcrübə ilə sıx bağlıdır. Metodika müəllimləri şagirdlərin tədrisi və tərbiyəsi nəzəriyyəsi ilə təchiz edir. 
Ölkəmizin inkişafının sosial-iqtisadi şərtlərinin, təməl elmin vəziyyətinin, məktəbdə coğrafiyanın tədrisi təcrübəsinin öyrənilməsi elmi inkişaf və həll yolları tələb edən aktual problemləri qabartmağa imkan verir (Душина, 2006: 256).

Hər hansı bir bilik sahəsi kimi, coğrafiyanın tədris metodikası da bir elm kimi coğrafiyanın tədrisi prosesini öyrənmək üçün metodlar hazırlamışdır. Bir coğrafiya müəllimi mövzunun metodologiyasında tədqiqat işi barədə bilik və bacarıqlara sahib olmalıdır. Bu, öz işini qiymətləndirmək, digər müəllimlərin təcrübəsini öyrənmək, özünütərbiyə və yaradıcı axtarış üçün lazımdır. Dialektik materializm, coğrafiyanın tədrisi prosesi də daxil olmaqla, gerçəkliyi tanımağın universal bir metodudur. Bu coğrafiyanın tədrisi üçün metodoloji əsasdır. Dialektik materializm bütövlükdə təhsil, tərbiyə və inkişaf prosesinin öyrənilməsinə xüsusi yanaşma və onu təşkil edən komponentlər və elementlər baxımından, həm də kəmiyyət dəyişikliklərinin keyfiyyət dəyişikliklərinə keçməsini ehtiva edir.

Nəzəri metodlar ümumiləşdirmələr yaratmağa, faktları təhlil etməyə, təlim prosesinin qanunauyğunluqlarını müəyyənləşdirməyə yönəlib. Bunlara:

1.sistem-struktur təhlili,

2.tipoloji yanaşma,

3.riyazi metodlar,

4.tarixi və müqayisəli metodlar daxildir.

Sistem-struktur analizinin mahiyyəti ondadır ki, tədqiqat mövzusu qarşılıqlı təsir göstərən komponentlərdən ibarət olan ayrılmaz bir sistem kimi qəbul edilir və diqqət bu komponentlər arasındakı əlaqələrin və qarşılıqlı əlaqələrin öyrənilməsinə yönəldilir. Buna uyğun olaraq, coğrafiyanın tədrisi prosesinin araşdırmalarında müəllim və şagirdin fəaliyyətləri (yəni tədris və öyrənmə) arasında, tədrisin məqsədləri, məzmunu, metodları və vasitələri arasında, mənimsənilməsi arasında əlaqələr aşkar olunur. Sistem-struktur təhlili dərsin məqsədlərinin müəyyənləşdirilməsini əhatə edir, məqsədlərlə əlaqəli, təlimin məzmunu, tədris metodları və üsulları, tədris avadanlı̆̆ 1 müəyyən edilir.

Sistemli bir yanaşma həm də müəllimin təbiətə uyğun olaraq hər dərsin funksiyalarını və bir-biri ilə əlaqələrini müəyyənləşdirərək müəyyən bir mövzuda bir neçə dərs planlaşdırması və inkişaf etdirməsində də özünü göstərir. məktəblilərin idrak fəaliyyətinin (Лисейчиков, 2012: 85).

Tipoloji yanaşma tədqiq olunan obyekt və hadisələri təsnif etmək və qruplaşdırmaq üçün istifadə olunur. Eyni zamanda, cisimlərin əsas xüsusiyyətləri, əlamətləri müəyyənləşdirilir, analiz aparılır və təhlil əsasında tədqiq olunan obyekt və hadisələrin qrupları ayrılır. Tipoloji yanaşma metodologiya elminin bütün problemlərinin öyrənilməsində tətbiqini tapır. Onun köməyi ilə məktəb coğrafiyasının məzmununun hissələri (bilik, bacarıq və dünyagörüşü fikirləri) ayrılır, tədris metodları və vasitələri təsnif edilir, dərs növləri, şagirdlərin müstəqil iş növləri və s. təyin edilir.

Coğrafiyanın tədrisi zamanı öyrənmə prosesini tədqiq etmək üçün dəqiq riyazi metodlardan istifadə olunmağa başladı. Yalnız tədqiq olunan obyektləri keyfiyyətcə qiymətləndirməyə deyil, həm də onları kəmiyyətcə ifadə etməyə, təlim prosesinin komponentləri arasındakı əlaqələri və asılılıqları daha dərindən öyrənməyə imkan verirlər (məsələn, tədris metodlarının təkmilləşdirilməsi hansı amillərə təsir göstərir).

Tarixi metodun mahiyyəti ondan ibarətdir ki, araşdırılan bütün hadisələr inkişafda, zaman dəyişikliyində nəzərə alınmalıdır. Bu metod coğrafiyanın tədrisi metodikasında sualların hazırlanmasında keçmişin təcrübəsinin nəzərə alınmasını tələb edir, bu proseslərin tarixi aspektdə necə dəyişdiyini, hansı mərhələləri keçdiyini analiz edir - yalnız bundan sonra gələcək üçün proqnoz veriləcək. Tarixi metodun köməyi ilə tarixi və metodoloji tədqiqatların məlumatları müasir coğrafiyanın tədrisi metodlarının problemlərinin öyrənilməsinə cəlb olunur. Müqayisəli tədqiqat metodu ümumiyyətlə məntiqi idrak metodudur. Müqayisə üçün tipoloji yanaşma aparılır, tədqiq olunan obyektlərin və hadisələrin təsnifatı aparılır. Müqayisəli metod coğrafiyanın tədrisində xarici təcrübənin öyrənilməsində də istifadə olunur. 
- Empirik tədqiqat metodları cogranın tədrisi zamanı mövcud pedaqoji təcrübəni öyrənməyə və ya yeni bir pedaqoji təcrübə yaratmağa yönəlib. Pedaqoji praktikada nə olduğunu müəyyənləşdirmək üçün aşağıdakı metodlardan istifadə olunur (Даринский, 2009: 23).

1.Öyrənmə prosesinin müşahidəsi. Müşahidənin məqsədi müəyyənləşdirilir, bir proqram hazırlanır, proqrama uyğun olaraq müşahidə prosesində faktlar qeydə alınır, işlənir, əldə edilmiş nəticələrin təhlili əsasında nəticələr çıxarılır.

2.Müəllim və şagirdlərin sorğusu. Anketin məqsədi müəyyənləşdirilir, anket hazırlanır, anket aparılır, məlumatlar işlənir.

3.Məktəb sənədlərinin öyrənilməsi (sinif jurnalları, tematik və dərs planları, dərnəklər üçün iş planları və s.). Tədqiqata əsasən məktəbdə tədris və tərbiyə işinin təşkili ilə bağlı müəyyən nəticələr çıxarılır.

4.Müsahibələr. Müsahibənin məqsədi müəyyənləşdirilir, müsahibə aparılır, bunun əsasında nəticələr və ümumiləşdirmələr aparılır.

5.Yazılı testlər. Şagirdlərin hazırlıq səviyyəsinin müəyyənləşdirilməsinə xidmət edir, əldə olunan nəticələrə görə, tədris prosesinin vəziyyətini bütövlükdə qiymətləndirirlər.

\section{Noticə}

Adətən coğrafiya fənninin tədrisində məlumat mübadiləsi mərhələsində tətbiq edilən iş üsullarını tədqiq edərkən məktəblərin pedaqoji təcrübəsini öyrənmək üçün metodların birləşməsindən istifadə olunur. Yeni pedaqoji təcrübə yaratmaq üçün pedaqoji eksperiment metodu nəzərdə tutulur. Eyni zamanda, tədrisə yeni bir iş üsulu gətirilir - yeni tədris materialı, yeni tədris metodu, yeni tədris vasitəsi və s. Bu yeniliyin şagirdlərin bilik keyfiyyətinə, inkişafina və təhsilinə necə təsir etdiyi açıqlanır. Təcrübə üçün nəzarət və təcrübə sinifləri seçilir. Təcrübə sinifində yeni bir öyrənmə elementi tətbiq olunur, nəzarət sinifində təlim ənənəvi olaraq aparılır və daha sonra şagirdlərin sinifdəki bilik keyfiyyətləri müqayisə olunur. Tədris zamanı pedaqoji təcrübə, elmi fərziyyə, lazımi tədris və metodiki material hazırlanır (yeni tədris mətni, yeni əyani vəsaitlər, test işi və s.). Yeni iş üsullarının tətbiqi isə öz növbəsində, biliklərin dərinləşməsinə və uşaqların müstəqilliyinin inkişafına kömək edir.

\section{Odəbiyyat}

1. Даринский А.В. Методика преподавания географии / А.В.Даринский. М., 2009.

2. Десятибалльная система оценки результатов учебной деятельности учащихся: инструктив нометодические материалы / под науч. ред. О.Е.Лисейчикова. Мн., 2012.

3. Душина ИВ. Методика преподавания географии / И.В.Ду-шина, Г.А.Понурова. М., 2006. c 256.

4. Жучкевич, В.А. Наглядность в преподавании географии / В.А.Жучкевич. Мн., 2013, с 320.

5. Левитес Д.Г. Практика обучения: современные образовательные технологии / Д. Г.Левитес. Воронеж, 2018

6. Понурова Г.А. Проблемный подход в обучении географии в средней школе/ ГА.Понурова. М., 2016, с 450. 
Məsumə Vasif qızı Məmmədli

Azərbaycan Turizm və Menecment Universiteti magistrant

m.memmedli1995@gmail.com

\title{
TəHSIL TURIZMI Və ONUN AZəRBAYCAN TURIZM IQQTISADIYYATINDA ROLU
}

\author{
Açar sözlor: turizm, təhsil turizmi, iqtisadiyyat, turizm nəzariyyasi, akademik turizm, təhsil
}

\section{Educational tourism and its role in the tourism economy in Azerbaijan Summary}

Educational tourism is one of the developing and innovative types of modern tourism. While this seems to be relatively new among the most common types of tourism, in fact, this tourism industry is older than we know its history. The origin, significance and source of educational tourism differ depending on the level of development of the country. Although educational tourism in Azerbaijan is relatively new, it already has a certain legal basis.

Key words: tourism, educational tourism, economy, tourism theory, academic tourism, education

Müasir turizm iqtisadiyyatın geniş çoxşaxəli sahəsinə çevrilərək, hal-hazırda dünyada ən gəlirli sahələrdən biri kimi çıxış edir. Etiraf edək ki, müasir gündəmimizi turizmsiz, səyahətlərsiz təsəvvür etmək çox çətin olardı. Hər birimiz ən azından ömrümüzdə bir dəfə də olsun səyahət etmişik və bununla da turist rolunu öz üzərimizə götürmüşük. İstər daxili turizm, istərsə də xarici turizm, turizm, ümumilikdə, istehlakçı ehtiyaclarına yönəlik bir sahədir. Bu ehtiyacları qarşılamaq üçün turizmin müxtəlif növləri meydana gələrək, turizm sahəsini getdikcə genişləndirir. $\mathrm{Bu}$ inkişafa birbaşa təkan mənasını kəsb edir.

Məhz bu inkişaf nəticəsində müxtəlif turizm növləri yaranır. Günbəgün artan turizm növləri arasında geniş yayılanlarla, məsələn, mədəni turizm, çimərlik turizmi, dağ turizmi kimi növlərlə yanaşı nisbətən daha yeni turizm növləri də var. Tədqiqatımızın əsas mövzusu da məhz turizm sahələri arasında nisbətən daha yeni olan "təhsil turizmi" anlayışı və bu turizm növünün Azərbaycanda mövcud inkişaf səviyyəsidir.

Bildiyimiz kimi, turizm sahəsinin növ müxtəlifliyi istehlakçıların, yəni turistlərin fəaliyyət məqsədləri ilə müəyyən edilir. Bu məqsədlər müxtəlif cür olur və ediləcək səyahətin növünü aydınlaşdırır. Osasən, məqsədlər iki cür ola bilər - əsas və ikinci dərəcəli. Osas məqsəd etdiyimiz səyahətin əsas səbəbi kimi çıxış edir. İkinci dərəcəli məqsədlər isə bir növ köməkçi məqsədlər kimi çıxış edib, turizm fəaliyyəti prosesində iştirak edir. Müəllif bu prinsipi rəhbər tutaraq, təhsil turizminə tərif verərkən, müəyyən bir seqmenti nəzərdə tutur ki, bu seqment üçün səyahətin əsas məqsədi kimi təhsil özü çıxış edir. Bu seqmentə Ritchie məktəb ekskursiyalarını, dil öyrənmə və universitetlərdə təhsili aid edir. Digər seqment üçün isə təhsil almaq bir növ ikinci məqsəd kimi çıxış edir və elə də mühüm əhəmiyyət kəsb etmədiyi üçün arxa planda turizm fəaliyyətində iştirak edir. $\mathrm{Bu}$ seqmentin üz tutduğu turizm növləri arasında təhsil turizminə rast gəlinmir, əsasən bura digər turizm növləri - ekoloji, mədəni və s.-ni aid etmək olar.

Hər bir səyahətçinin məqsəd və ehtiyaclardan irəli gələrək, təhsil turizminin də növləri mövcuddur. Turizm bazarında və ya tədris prosesində istifadə olunan təhsil səyahətlərinin mövcud növlərininin tədqiq edilməsi onun sahə və məqsədlər üzrə sinifləşməsinə gətirib çıxarıb:

- xarici dil tədrisi yönümlü;

- müxtəlif idman növlərinə yiyələnmə yönümlü;

- akademik təhsil yönümlü.

Ümumiyyətlə, təhsil turizminin Azərbaycandakı inkişaf səviyyəsindən danışsaq, onu da qeyd etmək yerinə düşərdi ki, bu turizm növü ölkəmizdə digər turizm növlərinə nisbətən daha yeni və elə də inkişaf etməmişdir. 
Təhsil turizminin əsas məqsədi əcnəbi tələbələrin təhsil almaları üçün ölkəmizə üz tutmasıdır. Hal-hazırda ən geniş yayılmış növü akademik təhsil turizmi sayılır.

Akademik təhsil turizmi dedikdə ilk öncə nə nəzərdə tutulur?

Akademik turlar dedikdə orta məktəb, universitet, onlara hazırlıq proqramları, həmçinin, "beynəlxalq akademik il" kurslar1, Foundation və digər proqramlar nəzərdə tutulur. Tələbə icması daha çox mobilliyi və ünsiyyətcilliyi, yerdəyişməyə can atması, səyahət və yeni bilik və məlumatlar axtarışında olmaları ilə seçilirlər. Buna görə, beynəlxalq təhsil əlaqələri dinamik inkişaf edən humanitar əməkdaşlığın perspektiv aspektlərindən biri sayılmalıdır. Çünki müasir beynəlxalq təhsil praktikası təhsilin bütövlükdə və yaxud hər hansı bir hissəsinin ölkə xaricində alınmasını nəzərdə tutur.

Hal-hazırda, universitet tələbələri üçün hazırlanan ən popular proqramlardan biri Avropaya inteqrasiya çərçivəsi daxilində qəbul edilən ERASMUS+ proqramıdır. Proqramda iştirak tələbələrə xarici dil biliklərini inkişaf etdirməyə, ünsiyyət bacarıqlarını təkmilləşdirməyə, şəxsi sərbəstliklərinin səviyyələrini artırmağa, ümumilikdə tələbənin sosial-mədəni təcrübəsini formalaşdırmağa, onların sosiallaşmasına imkan verir.

Təhsil turizminin ümumi ölkə iqtisadiyyatına, ələxsus, Azərbaycanın iqtisadiyyatına faydasından danışsaq, qeyd etmək yerinə düşərdi ki, təhsil turizmi bir neçə sahəyə eyni anda öz təsirini göstərir. Belə ki, "təhsil" olaraq, birinci növbədə təhsil turizmi təhsil sahəsinə təsir edir. Təhsil sahəsinin təkmilləşdirilməsi, təşkili, islahatların aparılması və s. kimi nəticələrə gətirib çıxarır. Nəticə olaraq, təhsil sahəsi əcnəbi turistlərin tədrisini təşkil etmək məqsədi ilə inkişaf edir, müxtəlif innovasiyaları özündə tətbiq etməklə təhsil sahəsini dünya standartlarına daha da yaxınlaşdırır.

İkinci sahə kimi, əlbəttə, iqtisadiyyatı və onun bilavasitə qolu olan turizmi göstərmək olar. Turistlərin ölkəyə axını iqtisadiyyata birbaşa təsir edən faktorlardan biridir. İlk növbədə sosialiqtisadi sahələr inkişaf edir. Bura nəqliyyat1, sənayeni, səhiyyəni və s. sahələri göstərmək olar. Çünki, turistlərin ölkəyə gəlişini təşkil etmək üçün ilk növbədə onların turizm destinasiyasına gəlmə vasitələrini təkmilləşdirmək, nəqliyyat infrastrukturunun (hava limanlarının, dəniz vağzallarının, avtomagistralların) təşkili və yenidənqurmasını tələb edir. Bununla da təkcə turizm sahəsi gəlir əldə etmir, ölkənin sosial-iqtisadi rifahı da yaxşılaşır.

Ümumiyyətlə, təhsil turizmi ölkəyə, həmçinin, gələcək potensial əmək resurslarını cəlb edir. Belə ki, ölkəyə cəlb olunan əcnəbi tələbələrin məzun olduqdan sonra ölkədə qalıb işləmələri üçün müəyyən imkanlar yaradılır. Çox vaxt bu imkanlar xarici şirkətlər tərəfindən yaradılır. Həmin şirkətlər tərəfindən təklif olunan təcrübə proqramları, qrantlar və təqaüdlər həmin əcnəbi tələbələrin ölkəyə cəlb olunmasında böyük rol oynayır. Belə ki, təhsil haqqının tam qarşılanması, təqaüd və yaşayış yeri ilə təmin olunma çox vaxt öz ölkələrində həmin ixtisaslara yiyələnmək imkanına malik olmayan tələbələrin bu qrantlardan yararlanaraq istədikləri ixtisasa yiyələnmələrinə səbəb olunur.

Azərbaycanda mövcud təhsil sistemində əcnəbilərin və vətəndaşlı̆̆ olmayanlar üçün təhsilin qanuni əsasları mövcuddur.

Azərbaycan Respublikası Nazirlər Kabinetinin 2015-ci il 1 may tarixli 125 nömrəli qərarı ilə “Azərbaycan Respublikası vətəndaşlarının təhsil almaq üçün xarici ölkələrə göndərilməsi və xarici ölkə vətəndaşlarının Azərbaycanın tədris müəssisələrində təhsil almaları Qaydaları" təsdiq edilməsi barədə qərar verilmişdir. Azərbaycan Respublikasının vətəndaşlarının xarici ölkələrin təhsil müəssisələrində, əcnəbilərin və vətəndaşlı̆̆1 olmayan şəxslərin tabeliyindən və mülkiyyət formasından asılı olmayaraq təhsilin bütün pillə və səviyyələri üzrə Azərbaycan Respublikasının təhsil müəssisələrində, həmçinin ali təhsilin doktorantura və magistratura səviyyələri üzrə elmi müəssisə və təşkilatlarda və tibb təhsilinin rezidentura səviyyəsi üzrə klinik bazalarında təhsil almasına dair ümumi tələbləri müəyyən edir.

$\mathrm{Bu}$ qaydalara əsasən, əcnəbilərin təhsil müəssisələrində əvvəlki təhsilinə uyğun gələn təhsil səviyyəsinə və ya əlavə təhsilin hər hansı istiqamətinə qəbulu aşağıdakı əsaslarla həyata keçirilir:

- təhsil sahəsində Azərbaycan Respublikası ilə xarici ölkələr arasında bağlanılmış müqavilələrə uyğun müəyyənləşdirilmiş kvota əsasında; 
- təhsil müəssisələrinin iştirak etdiyi beynəlxalq proqramlar əsasında;

- dövlət tərəfindən müəyyən edilmiş təhsil qrantı proqramı əsasında;

- təhsil müəssisələri ilə xarici ölkələrin təhsil müəssisələri arasında bağlanılmış müqavilələr əsasında;

- təhsil müəssisəsinin hüquqi şəxslərlə birbaşa bağladığı müqavilələr əsasında;

- təhsil müəssisəsinin fiziki şəxslərlə birbaşa bağladığı müqavilələr əsasında;

Azərbaycan təhsil sistemini dünyəvi adlandırsaq yanılmarıq. Çoxəsrlik təşəkkül tarixinə malik təhsil sistemimiz müstəqilliyimizin bərpasından sonrakı dövrdə əcnəbi tələbələrin qəbulu üçün hər bir şəraiti təmin etmişdir. Belə ki, müstəqilliyimizin bərpasından sonra, əsasən 90-c1 illərdə Azərbaycanda kütləvi şəkildə beynəlxalq məktəblərin açılışları başlamışdır. Bunlar arasında ilk pillələrdə türk liseyləri dururdu ki, o dövrün ən popular özəl məktəblərindən biri say1la bilərdi. Bu tip məktəblər təkcə Bakı və Abşeronda deyil, Şəmkir və Azərbaycanın digər bölgələrində də filialları açılmışdı.

Ogər türk liseylərində təhsil türk dilində aparılırdısa, Azərbaycan Beynəlxalq Məktəbi, Bak1 Fransız Liseyi, Bakı Oksford Məktəbi kimi digər özəl məktəblərdə təhsil ingilis və fransız dillərində aparılırd1. Təhsilin əcnəbi dillərdə olması əcnəbi tələbələrin tədrisi üçün əlverişli şərait yaradır. Beləliklə də, əcnəbi tələbə və şafirdlərin qəbulunu həyata keçirmək üçün imkan yaradılmış olur.

Təhsil turizmi hələ yetərincə inkişaf etməmiş bir turizm sahəsidir. Bu sahənin Azərbaycan turizm iqtisadiyyatında yetərincə tanınmaması onun ölkəmizdə mövcud potensialını heçə saymaq demək deyil. Azərbaycanda bu sahənin inkişafi üçün yetərincə potensial var. Təkcə akademik turizm deyil, həmçinin yerli mətbəxi öyrənməyə imkan verən qastronomik turizm, öz dilimizi və mədəniyyətimizi təbliğ etmək üçün mədəniyyət mərkəzlərinin yaranması üçün də imkanlar mövcuddur.

\section{Odəbiyyat}

1. American Heritage Dictionary of the English Language (2011) Field trip. Houghton Mifflin Harcourt Publishing Company. Fifth Edition. Retrieved

from http://www.thefreedictionary.com/field+trip

2. British Dictionary. (2012) Field trip. Retrieved from http://dictionary.reference.com/ browse/field-trip Cambridge Dictionaries Online. Field trip. (2016) Cambridge University Press. Retrieved from http://dictionary.cambridge.org/dictionary/english/field-trip

3. Dictionary of Unfamiliar Words by Diagram Group. (2008) Field trip. Copyright by Diagram Visual Information Limited. Retrieved from http://www.thefreedictionary. com/field+trip

4. Moscardo, G. (2016). Building Excellence in Sustainable Tourism: 15 years of Building Excellence in Sustainable Tourism Education Network (BEST EN) practice. Journal of Cleaner Production Volume 111, Part B, 16 January, 538-539. Retrieved from http://www.sciencedirect.com/science/article/pii/S0959652615013773

5. Paul, K., \& Larson, T. (1999). Educational Tourism: A Strategy to Sustainable Tourism Development in Sub-Saharan Africa. Retrieved from http://www. Earthwatch.org/

6. Procter, L. (2012). What is about Field Trips? Praxis, Pedagogy and Presence in Virtual Environments. Social and Behavioral Sciences, 55, 980-989.

7. Programmas ERASMUS+ vadlīnijas. Versija $1 \quad$ (2016): 20/10/2015. Retrieved from http://ec.europa.eu/programmes/erasmus-plus/index lv.htm

8. Aleksandrou, A., \& Field, K. (2005). The continuing Professional Development of Education. London, Simposium Books, 9-24

9. B. Ritchie (2003). Managing Educational Tourism. P 16-23

10. http://e-qanun.az/framework/19800

11. http://e-qanun.az/framework/29964

12. http://e-qanun.az/framework/18344 


\section{RUSIYYADA BEYNəLXALQ TURIZMIIN İNKIŞAF TENDENSIYYALARI}

Açar sözlor: Beynalxalq turizm, turizm işi, turizm sənayesi, turizm infrastrukturu, turizm xidməti, Rusiya turizmi, turizm bölgalari

\section{Trends in the development of international tourism in Russia Summary}

This article discusses the conditions of international tourism in Russia at the moment. This includes inbound and outbound tourists, key issues and future trends of this branch, expected and forecast information, the main problems of the tourism industry in Russia are reflected, some areas of reform and prospects for tourism development are highlighted. Historical and cultural natural heritage is one of the most attractive sources of tourism in Russia. Russia is traditionally considered a country that makes a great contribution to world culture. In addition, many unique historical and cultural monuments are concentrated in the country. In order to improve the quality of tourism products in the Russian Federation, it is necessary to ensure the large number of tourist programs offered in the market and their periodic updating. This will increase consumer interest in tourism products and increase the number of repeated visits to resorts and tourism infrastructure facilities.

Key words: International tourism, tourism business, tourism industry, tourism infrastructure, tourism services, Russian tourism, tourism regions

\section{Giriş}

Rusiya Federasiyası sənayenin bütün sahələrində uzunmüddətli davamlı turizmin inkişafı üçün böyük potensiala malikdir. Bunun mümkün olmasına kömək edəcək əsas amilləri və Federasiyanın yaxın gələcəkdə qarşılaşacağı bəzi xüsusi vəziyyətləri və imkanları müəyyənləşdiririk. Bu bölmə xüsusilə bir sıra meyllərə və bunların Rusiyada turizmə necə təsir etdiyinə baxacayı. Son 50 ildə dünyanın turizmdə yuxarıda göstərilən dəyişiklikləri Rus turizmində əks etdirir. Vaxtilə elit insanlarla məhdudlaşan beynəlxalq səyahətlər indi ölkə əhalisinin daha böyük bir hissəsində əldə edilə bilər.

Rusiya Federasiyası da daxil olmaqla, hər hansı bir ölkədə turizmin inkişaf dərəcəsi, böyük ölçüdə infrastrukturun və turist xidmətinin inkişaf səviyyəsi, ərazinin turist qəbul etmək qabiliyyəti, ekoloji vəziyyət, iqtisadi səviyyə ilə müəyyən edilir. turistlərə ev sahibliyi edən bölgənin inkişafi, əmək resursları, maddi ehtiyatları və maliyyə imkanları ilə təmin edilməsidir. Hal-hazırda, Rusiyanın ənənəvi kurort yerlərinə səyahətlərə artan tələbat var. 2016-c1 ilin turizm mövsümü Rusiya kurortlarında istirahətə böyük maraq göstərdi.

Turizmin inkişafinın ən vacib istiqaməti turizm məhsulunun fərqləndirilməsi, həm xarici turistlər, həm də sakinlər üçün yeni turizm növlərinin və istiqamətlərinin inkişafıdır. Təhlil göstərir ki, hazırda Rusiyada daxili turizmin aşağıdakı inkişaf sahələri ən populyardır:

1. Ekskursiya turları (Moskva, Sankt-Peterburq, "Q1zıl üzük" şəhəri-Vladimir, Suzdal, Novgorod, Rostov və s.).

2. Q1şda ovçuluq və balıq ovunun təşkili - daxili turizmin inkişaf edən sahələrindən biridir.

3. Macəra turizmi. Altay çayları boyunca təşkil olunan rafting, Volqa sahilləri boyunca atlar, Altay, Başqurdistan, Nijni Novgorod bölgəsində və s.

4. Ekoloji turizm, turistlərin xüsusi gəzinti səfərləri etdiyi ölkənin müxtəlif bölgələrində fəal şəkildə inkişaf edir. qoruqların və milli parkların inkişaf etmiş marşrutları. Son illərdə Rusiyada təbii və ya ekoloji turizm getdikcə populyarlaşır. İqtisadi üstünlükləri var.

Yaxın gələcəkdə turizm sənayesinin aşağıdakı inkişaf sahələri proqnozlaşdırıla bilər: 
- Turist ölkələrində turistin (təbii, mədəni, mədəni, mədəni, mədəni və tarixi) resursları nəzərə alınan mövcud turizm xidmətləri, bazarların yeni və inkişafı yaradılması;

- yerli icma və bələdiyyə orqanlarının turistik fəaliyyətinin planlaşdırılması və inkişaf etdirilməsində, təhlükəsizliyini təmin etməkdə geniş yayılması;

- Hər birinin ehtiyaclarını dərk etmək və bələdiyyə quruluşları arasındakı əlaqələrin inkişafı;

- Yerli əhalinin rifahının artması, turizmin inkişafına müdaxilə edə biləcək vergi, adət və digər çətinliklərin aradan qaldırılması;

Eyni zamanda, turistlər üçün məqbul olan səviyyələrdə və turizm sənayesi üçün sərfəli olan səviyyələrdə turizm xidmətlərinin qiymətinin qorunmasına xüsusi diqqət yetirilməlidir;

- Kapital investisiya kapitalı ətraf mühit məsələlərini (tikinti, memarlıq, antropogen yük) nəzərə almalıdir;

- Xidmətlərin təbliği üçün daha çox resursların tətbiq edilməsi, turistlərin müəyyən qruplarının axtarış1;

- Turizm sənayesinin işçilərinin peşə səviyyəsinin yaxşılaşdırılması;

- Bir tətil sahibliyi sisteminin inkişafi.

Turizmə investisiya həmişə Moskvaya və Sankt-Peterburqa yönəldilmişdir. Osas beynəlxalq tədbirlər də əsasən Moskvada və ya Sankt-Peterburqda keçirilmişdir. Bununla birlikdə, son illərdə Rusiyanın digər böyük şəhərləri olan Kazan, Yekaterinburg, Kaliningrad, Soçi və Perm də Rus və beynəlxalq iş və birliklər üçün konfrans və sərgilərə ev sahibliyi etdi.

$\mathrm{Bu}$, yaxın on ildə rusiya turizmi üçün ən böyük çətinliklərdən və fürsətlərdən biridir. Rusiya şəhərləri özlərini daha geniş bir bölgəyə çıxışı olan bir iş hadisəsi mərkəzinə çevirə bilərlər: Baltik bölgəsi üçün Sankt-Peterburq; Qara dəniz və Şərqi Aralıq dənizi üçün Soçi; və s. Rusiya investisiya qabiliyyətinə, İT bacarıqlarına, bəzi hadisələrin idarə olunması təcrübəsinə və digər aktivlərə malikdir. Siyasi iradə olsaydı, infrastruktur, yaşayış və qonaq xidmətlərindəki mövcud zəifliklərin öhdəsindən gəlmək olar.

Rusiya üçün müsbət olan beynəlxalq turizmin inkişaf tendensiyaları aşağıdakılardır:

- Rusiya Federasiyası son illərdə gələn axının yüksək artım templərini nümayiş etdirir və xarici vətəndaşları qəbul edən on liderdən biridir;

- qısamüddətli dövrdə turistlərin sayında artım sürət azalsa da davam edəcək;

- turizm xərclərinin artım proqnozu göstərir ki, bir sıra ölkələrdəki əlverişsiz iqtisadi vəziyyətə baxmayaraq, turistlər xərclərini azaltmırlar və bu tendensiya yaxın on ildə də davam edəcək;

- Xaricdəki fəaliyyətdəki ən böyük böyümə, Rusiya Federasiyasına qonşu olan Asiya-Sakit okean bölgəsi ölkələri tərəfindən göstərilir, Qərbi Avropanın inkişaf etmiş ölkələri isə turizm axınının əsas donorları olaraq qalır;

- dünyada artan siyasi qeyri-sabitlik nəticəsində Yaxın Şərqin bir çox ölkəsi artıq ruslar üçün cəlbedici turizm məkanı deyil;

- qeyri-sabit siyasi vəziyyəti olan ölkələrdən sakinlərin turist səfərlərinin sayı artır və bu da Rusiya turizm məhsullarının daxili və beynəlxalq turizm bazarlarında rəqabət qabiliyyətini artırmaq imkanı yaradır;

- dünyada Rusiya, xarici turistlər üçün Rusiya Federasiyasını ən cəlbedici turizm məkanı edən mədəni, təhsil və təbiətə yönəlmiş turizmə mară̆ın artması;

- Turizm, təcrübəli bir səyyahın iqtisadi və ya siyasi təhdidlərin təsiri nəticəsində belə imtina edə bilməyəcəyi müasir insanlar üçün vacib bir ehtiyac halına gəldi.

Eyni zamanda, beynəlxalq turizmin inkişafında Rusiya Federasiyası üçün aşağıdakı mənfi tendensiyaları nəzərə almaq lazımdır:

- Rusiya Federasiyası dünyada turizm axınının ən böyük donorlarından biridir;

- əcnəbilərin Rusiya Federasiyasına girişinin iki rəqəmli artım sürətinə baxmayaraq, daxili iqtisadiyyat əlverişli tendensiyadan səmərəli istifadə edə bilmir və turist axınının oxşar artım tempi ilə digər ölkələrə nisbətən turizmdən təxminən beş dəfə az qazanır; 
- Rusiya Federasiyasına gələn bir turizm axını cəlb edən beynəlxalq tədbirlər rusiyalı turistlərin cəlb edilməsi və onların keçirilməsinin iqtisadi effektinin artırılması vəzifəsini tam yerinə yetirmir;

- xarici mühitin siyasi, texnogen və təbii amillərinin təsiri nəticəsində ruslar üçün ənənəvi hala gələn ənənəvi kütləvi turizm bölgələrindəki turistlərin təhlükəsizliyinə təhdidlər;

- beynəlxalq turizm sahəsində artan rəqabət turizm sənayesini aşağ1 mənfəətli edir və Rusiya Federasiyasının daxili turizm məhsulu qiymət baxımından rəqabətə davamlı deyil.

Bir neçə ildir Rusiyaya gələn xarici turizm axınının azalmasının əsas səbəbi yüksək qiymətlər, həmçinin viza sisteminin mürəkkəbliyi və ağırlığıdır. Son bir il yarımda tur paketinin bütün komponentləri bahalaşd1 - yaşayış, dəmir yolu nəqliyyatı, hava nəqliyyatı, muzeylərə giriş biletləri və s. Bütün bunlar rus operatorlarının təklifini rəqabətsiz edir. Standart bir Moskva-Sankt-Peterburq turunun qiyməti 1500 dollardır və Parisə bir turun qiyməti ilə müqayisə etmək olar.

Rusiyaya xarici turist axınının azalmasının digər, daha az əhəmiyyətli bir səbəbi, ucuz üçulduzlu otellərin çatışmazlığıdır. Üstəlik, bu kateqoriyaya daxil olan bir çox yeni tikilmiş otellər olduqca bahalı çıxır və mövcud problemlərlə əlaqədar problemi daha da artırır. Məsələn, Moskva Holiday Inn (3 ulduzlu status) 200 dollarlıq otaqlar təklif edir. və daha yüksək. 5.5 min yataq üçün nəzərdə tutulmuş "Rossiya" otelinin sökülməsindən sonra vəziyyət daha da mürəkkəbləşdi. Bundan əlavə, yüksək qiymətə belə, otellər nadir hallarda beynəlxalq standartlara cavab verən şərtlər təqdim edirlər. Rahatlıq səviyyəsinə görə, Rus otellərinin təxminən $80 \%$-i bir ulduz da ala bilmir, beş ulduza gəldikdə, əsasən Moskva, Sankt-Peterburq və Soçidə yerləşən rus otellərinin yalnız 1\%-i belə yüksək reytinqə malikdir.

Xülasə etsək, Rusiya Federasiyasında turizm son 20 ildə çox böyük addımlar atdı, lakin rəqabətə davamlı beynəlxalq hədəf olmaq üçün hələ bir yol qət etməlidir.

- Yollar və nəqliyyat limanı da daxil olmaqla infrastruktura investisiya qoyulmuşdur, lakin ölkənin böyük olması bunun yavaş bir proses olacağı deməkdir;

- Beynəlxalq turizm üçün bu infrastruktur məsələləri viza almaq kimi inzibati əngəllər kimi bir məhdudiyyətdir. Sankt-Peterburqun vizasız səyahət barədə ümumi təşəbbüsünün ümumiləşdirilməsinə ümid bəsləməliyik;

- Rusiyanın ikinci dərəcəli şəhərləri astravel mərkəzləri və iş yerləri meydana çıdıqca iş turizmi böyüyəcək;

- Onsuz da işgüzar səyahət tələbini ödəmək üçün ziyarətçilərin xidmətlərinə, xüsusən də otellərə investisiya qoyulmuşdur. Bu, ilk növbədə bazarın ən yüksək səviyyəsinə çatmışdır. İndi bazarın bütün seqmentlərinə ünvanlanan niş məhsulları daxil olmaqla xaricdən gələn təkliflərin inkişafını görürük;

- Səyahət və sifariş texnologiyası Avropa və Şimali Amerikaya nisbətən daha az inkişaf etmişdir, lakin Rusiya bu vəziyyəti yaxalamaq üçün texniki bacarıqlara sahibdir və tezliklə bunun baş verdiyini görmək ehtimalı var;

- Soçi Olimpiadasından sonra turizmin inkişafi üçün tədbirlərdən istifadə olunmağa davam ediləcək (məsələn, FIFA Dünya Kuboku);

- Başlanğıcda Moskva, Sankt-Peterburq və Soçi kimi majorturizm mərkəzlərində turizm planlaşdırması daha mürəkkəb hala gəlir. Müvəffəqiyyətin açarı universitetlər və xüsusi peşə məktəbləri vasitəsilə təhsil olacaqdır. Daha yaxşı iş və strateji planlaşdırma bacarıqlarına və turizmin iqtisadi sürücüsü kimi əhəmiyyətini dərk edən yeni bir nəsil yetişir. Bu nəslin təsiri növbəti 10 və 20 il ərzində görüləcək. Başqa bir əsas məqam da Rusiyanın öz ölkəsi imicini və turizm markasını necə idarə etməsi olacaq. Məqalədə aparılan araşdırmalar göstərir ki, təyinat şəkli turistlərin təyinat atributları barədə təsəvvürlərini, əsasən media vasitəsi ilə görsənir.

\section{Notico}

Məqalədə bir sira qlobal və Rusiyaya xas olan məsələlər və tendensiyalar nəzərdən keçirilmişdir. Millətlərarası və milli mühitdəki mövcud dəyişikliklərin onların vəziyyətinə necə təsir göstərə biləcəyini müəyyənləşdirmək və həll etmək hər bir səyahət mütəxəssisinə aiddir. Turizm 
qlöballaşmadan çox təsirlənir: Beynəlxalq səyyahlar gediş-gəliş yerlərində və iş yerlərində dəyişikliklərə kömək edir. Rəqabətə davamlı olmaq üçün xalq və turizm təchizatçıları bu dəyişikliklərdən xəbərdar olmalı və yenilikçi strategiya və xidmətləri tətbiq etməlidirlər. Yalnız son zamanlarda beynəlxalq turizmi mənimsəyən bir ölkə olaraq, Rusiya çoxsaylı problemlərlə üzləşir və getdikcə beynəlxalq səyahət təcrübəsi qazanan milli qonaqların yanında beynəlxalq ziyarətçilərin gözləntilərinə cavab vermək üçün tez bir zamanda uyğunlaşmalıdır.

\section{Odəbiyyat}

1. М. Портер. Международная конкуренция. М. Междунар. отношения, 1993

2. А.Ю.Александрова. Международный туризм: учебник / А.Ю.Александрова. - 2е изд.М.: КНОРУС, 2010;

3. А.Ю.Александрова. Пространственная поляризация мирового туристического рынка. Туризм и рекреация: фундаментальные и прикладные исследования / МГУ. М., 2008;

4. Р.А.Юрик Рынок международного туризма// Экономика и организация туризма. Международный туризм. - Под ред. И.А.Рябовой, Ю.В.Забаева, Е.Л.Драчевой. - М.: КНОРУС, 2005. 82

5. Касумов Руфат. Рынок международного тризма: теория и практика. Баку, Нурлан, 2001.

6. Азар В.И., Туманов С.Ю. Экономика туристского рынка. М, 1998. 17.Александрова А.Ю. Международный туризм. Учеб. пособие для вузов. М. 2001.

7. Харрис Годфри, Кац Кеннет. Стимулирование международного туризма в 21 веке. Пер. с англ. М.,2000.

8. Экономика и организация международного туризма / Под ред. Л.Ф.Ходоркова. М., 1984.

9. Экономика современного туризма. /Под ред. Г.А. Карповой. М., 2012. 
Ayton Zaman qizı Rəsulova

Azərbaycan Turizm və Menecment Universiteti

Magistrant

aytan.rasulova@zeytunpharma.az

\title{
BEYNOLXALQ TURİZM İNKISAFINA TOSİR EDəN AMILLLOR
}

\author{
Açar sözlor: Turizm, beynalxalq turizm, inkişaf
}

\section{Factors affecting the development of international tourism Summary}

The modern era is a period of rapid development. This speed, in turn, leads to the economic, cultural and political globalization of countries. An environment of globalization directly or indirectly affects the growth of tourist travel. The most important factors influencing the development of international tourism are: increase in leisure time, spread of paid vacation rights, development of modes of transport, increase in income levels, technological development, urbanization and population growth, freedom of travel, social security, education and culture, prolongation of human life, promotion of the state. This article discusses the factors affecting the development of international tourism.

Keywords: Tourism, international tourism, development

Hər il milyonlarla insan daimi yaşayış yerlərindən müvəqqəti olaraq digər bölgələrə və ya ölkələrə köçür. Bu hərəkət zamanı onlar yaşayış, nəqliyyat və infrastruktur imkanlarından faydalanırlar. Turizm fəaliyyəti müasir cəmiyyətə xas bir hadisə kimi ifadə olunsa da, yerdən-yerə hərəkət insanlıq tarixi qədər köhnə dövrlərə gedib çıxır. İnsanlar yüz illərdir müxtəlif səbəblərdən mövcud yerləri xaricində başqa yerlərə köçmüşlər. Daha sonra davamlı hala gələn bu hərəkətlər fərqli dillərdə fərqli terminlərlə ifadə olunmağa çalışıldı. Nəticə etibarilə maraqlar "turizm" sözünə köklənmişdir.

Turizm anlayışı Latın dilində dönmə mənasını verən "tornus" sözündəndir. İngilis dilindəki "gəzinti" və "tur" sözləri bu söz kökündən qaynaqlanır. Bu gün istifadə etdiyimiz turist kəlməsi, səyyah sözünün ekvivalenti olan traveller 1800-cü illərin əvvəllərində Samuel Pegge tərəfindən istifadə edilmişdir. Turizm sözü ilk dəfə İngiltərənin idman jurnalı tərəfindən 1811-ci ildə istifadə edilmişdir. "Səyyah" sözü "turist" kimi qəbul edilir. "Səyahət" sözü "turizm" deməkdir. (5)

İlk dəfə Guyer-Feuler tərəfindən 1905-ci ildə təyin olunan turizm, "hava dəyişikliyinə və rahatlamaya artan ehtiyac, təbiət və sənətdən bəslənən göz oxşayan gözəllikləri tanımaq istəyi; Təbiətin insanlara xoşbəxtlik bəxş etdiyi inancına əsaslanır. Ticarət və sənayenin inkişafı həmçinin nəqliyyat vasitələrinin mükəmməlliyi nəticəsində xalqların və icmaların bir-birinə yaxınlaşmasına imkan verən müasir dövrə xas bir hadisədir.". (7)

Turizmin inkişafına təsir göstərən ən vacib amil boş vaxtın yəni asudə vaxtın artmasıdır. Son bir neçə yüzillikdə sürətli sənayeləşmə və texnologiyanın inkişafı ilə işçi qüvvəsinə tələbin azalması nəticəsində məhsul və xidmətlər istehsalı üçün tələb olunan vaxt azaldı. Buna paralel olaraq artan sosial təzyiqlər insanların asudə vaxtlarının artırılmasına səbəb oldu. İnsanlar asudə vaxtın vacibliyini dərk etməyə başladıqca, bu məsələni getdikcə daha çox qəbul edildi və asudə vaxt, xüsusən 20-ci əsrdə davamlı artmağa meyl etdi. Bu tendensiya bu gün də davam edir. Beynəlxalq təşkilatlar və hökumətlər də asudə vaxtların təmin edilməsində rol oynayır. Beləliklə, asudə vaxtın artması turizmə olan tələbi artırd1.(1)

Turizmin inkişafina təsir göstərən digər faktor isə ödənişli tətil hüququnun yayılmasıdır. Birinci Dünya Müharibəsindən sonrakı illərdə sənayeləşmiş İngiltərədə artan sosial təzyiq, işçilərə ödənişli məzuniyyət hüququnun verilməsi ilə nəticələndi. İlk növbədə (1925-ci illər) 1,5 milyon işçini əhatə edən bu hüquq 1930-cu illərdə bütün işçiləri əhatə etmək üçün yenidən təşkil edildi. Beynəlxalq 
təşkilatlar və işçi təşkilatlarının töhfələri ilə bu hüquq qərb ölkələrində geniş yayıldı. Beləliklə, turizm fəaliyyətinə tələb artmağa başladı.(2)

Turistlərin rahat səyahəti üçün isə nəqliyyat növlərinin inkişafı da vacibdir. Turizm bir yerdən başqa yerə səyahət etmək olduğundan nəqliyyat texnologiyası turistik fəaliyyətlərə birbaşa təsir edən bir amildir. Sənaye inqilabı ilə paroxodların meydana gəlməsi və sonrakı dövrdə ardıcıl olaraq dəmir yolu nəqliyyatının və avtomobillərin geniş yayılması ictimai nəqliyyatın yayılmasına və nəqliyyat xərclərinin azalmasına səbəb oldu. 1950-ci illərdən sonra hava nəqliyyatının ortaya çıxması turizm hərəkəti baxımından bir inqilaba gətirib çıxardı. Nəqliyyat daha rahat, daha sürətli olduqca və ucuzlaşdıqca turizm hərəkatları daha sürətlə inkişaf etməyə başladı.(3)

Ohalinin gəlir səviyyəsindəki artım sosial həyata edilən xərcləmələri də artırır. Turizm pul xərcləməyi tələb edən bir fəaliyyətdir. Buna görə gəlir səviyyəsi ilə turizmə olan tələb arasında birbaşa əlaqə mövcuddur. Texnoloji inkişaf və sənayeləşmə ilə inkişaf etməkdə olan ölkə iqtisadiyyatları rifahı artırdı və gəlirlərin ortalamalarını artırdı. Gəlirlərin artması turizmə olan tələbatı və populyar turistik fəaliyyətləri də artırdı. Gəlir səviyyəsi ilə turizm arasında müsbət bir əlaqə var, çünki gəlir artdıqca səyahət daha lüks bir hala gəlir. (7)

Müasir dövr texnoloji inkişaflar dövrüdür. Texnoloji inkişafla birlikdə nəqliyyat sahəsindəki rahatlıq və xərclər azaldı, turizm və yerləşdirmə müəssisələrində xidmət keyfiyyətində artım; Buna paralel olaraq, iş həyatında texnologiyanın tətbiqi ilə iş saatlarının azalması, informasiya texnologiyalarının inkişafı ilə turizm müəssisələri və fəaliyyətləri haqqında daha çox məlumat, daha asan planlaşdırma və rezervasyonlar turizmə olan marağı və tələbi artırdı. (5)

Sənayeləşmə ilə insanların şəhərlərə sürətli köçü şəhər əhalisini artırdı və şəhərləşmə fenomeni ilə fərqli ehtiyac və gözləntilər ortaya çıxdı. Şəhərlərin və iş həyatının inkişafında lazım olan təcrübə təhsil fəaliyyətlərini sürətləndirdi və cəmiyyətdə məlumat mübadiləsini genişləndirdi. Artan əhali şəhər həyatının səs-küyünü, stresini və çirklənməsini artırdı və insanlar asudə vaxtlarından səyahət edərək istifadə etməyə başladılar.

Ümumdünya İnsan Haqları Bəyannaməsinin 13-cü maddəsi "Hər kəsin sərbəst hərəkət etmək və istənilən dövlətin sərhədləri daxilində yerləşmək hüququ vardır." (6) insanların səyahət azadlığını təmin etdiyini bildirir. A.R. Konstitusiyanın Turizm haqqında qanununda, insanların xaricə səyahət etmək hüququnun hakimlər tərəfindən yalnız cinayət istintaq1 və ya ittiham səbəbi ilə qarşısını ala biləcəyi müddəası var. Bu hüquq turizm fəaliyyətinin təbliği və genişləndirilməsi üçün vacibdir.(4)

Sosial təminat, müxtəlif səbəblərdən gəlirləri müvəqqəti və ya daimi olaraq kəsilən insanların həyatlarını davam etdirmələri üçün yaradılmış bir sistemdir. Sosial təminatı olmayan insanların turizm fəaliyyətində iştirakı mümkün deyil. Buna görə sistemin inkişafı turizmdəki inkişafa birbaşa təsir göstərir.

Dünya üzrə təhsil və mədəniyyət səviyyəsinin artırılması da insanların öz zamanlarını daha doğru dəyərləndirməyə zəmin yaradır. Sənayeləşmənin təsiri ilə insanlar işləmək üçün şəhərlərə axın etdilər və təhsil fəaliyyətləri şəhərlərin inkişafı ilə yayılmağa başladı. Təhsil və mədəniyyət səviyyəsindəki artımla paralel olaraq insanların maraq və araşdırma istəyi artır. Buna görə də bu artım səyahət etmək istəyini də artırır.

İqtisadi, sosial və texnoloji inkişaflar insanları müsbət təsir etdi və eyni zamanda səhiyyə sahəsindəki yeniliklər bu inkişaflarla paralel olaraq insanların həyat səviyyələrini və ömrünü artırdı. Xüsusilə inkişaf etmiş ölkələrdə səhiyyə sahəsindəki böyük addımlar insan ömrünün artmasına və yaşlı əhalinin artmasına səbəb oldu. İnsanların təqaüdə çıxarkən sıx boş vaxtlarının olması, təqaüdçüləri stresdən uzaqlaşmaq, səyahət etmək və sağlamlıqlarını qorumaq üçün turizm fəaliyyətlərində iştirak etməyə təşviq edir. Buna görə də insan ömrünün uzadılması turizmdəki iştirakı kəmiyyətcə artırır.

Hər bir sahədə olduğu kimi turizmdə də dövlət təşviqi xüsusi rola malikdir. Turizm fəaliyyətlərinin iqtisadi və sənaye ölçüsü hökumətlərin və özəl sektorun turizmə olan marağını artırdı. Səyahət bu gün bir zərurətə çevrildiyi üçün sıx turizm hərəkatları görünməyə başladı və bu bölgədən turistləri cəlb edən ölkələrin iqtisadi gəlirləri yüksək səviyyələrə yüksəldi. Çünki turizm 
valyuta axınına, məşğulluğun artmasına və ödəmə balansına kömək edir; Bu gəlir və rifah artımını təmin edir. Bundan əlavə, turizmə maddi-texniki dəstək verən kənd təsərrüfat1, sənaye və xidmət sahələrində inkişafa paralel olaraq istehsal və məşğulluq artımı təmin edilir. Turizm hökumətləri tərəfindən infrastrukturun və üst quruluşun inkişaf etdirilməsinə yönəldilən bu imkanlar yerli əhalinin həyat səviyyələrini artırır. Eyni zamanda, investisiya prosesləri, vergi və enerji mənbələrindən azadolmalar, yerli və xarici investorlar üçün təşviq kimi işlər turizmin inkişafına səbəb olur.

\section{Odəbiyyat}

1. https://ec.europa.eu/environment/archives/caring/en/caring9_en.pdf

2. https://www.historyextra.com/period/20th-century/holiday-revolution-were-all-going-on-asummer-holiday/

3. Westlake J. and D. Robbins (2005). "Transportation" in Cooper C., Fletcher J., Fyall A., Gilbert D. and S. Wanhill (eds), Tourism: Principles and Practice, 3rd edition, Pearson Education Limited, Essex

4. http://www.e-qanun.az/framework/4759

5. Buhalis, D. and Schertler, W. (eds). 1999. Preface. In Information and Communi- cation Technologies in Tourism, ed. D. Buhalis and W. Schertler, pp. v-vi. New York: Springer.

6. https://www.ohchr.org/documents/publications/handbookparliamentarians.pdf

7. https://yourdecision.oten.tafensw.edu.au/pluginfile.php/340/mod_page/content/83/Tourism \%20Sample\%20Unit/social_and_cultural_impact_of_tourism.html 


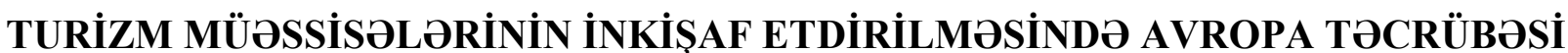

\author{
Açar sözlor: turizm, Avropa tacrübəsi, turizmin inkişafi, turizmin növlori
}

\section{European experience in the development of tourism enterprises Summary}

If we analyze the experience of developed countries, we can see that tourism is increasing in importance for the development of the countires over the years. Tourism plays a significant role in shaping the state budget and moving towards a positive trade balance. In order to catch this desirable trend in developed countries, first of all, it is important to allocate certain funds from the state budget for the improvement of tourism and to establish the necessary control mechanism to ensure the proper use of these funds. Fortunately, our state is very interested in the development of this area. This can be seen in the series of progressive steps taken by Azerbaijan since 2001, when it became a member of the UN World Tourism Organization, for the development of tourism. But how to increase the effectiveness of these steps? -The answer we are looking for has led us to scrutinize the practices of leading European countries in the field of tourism. In this article, we will try to analyze the achievements of the pioneers in tourism to some extent.

Key words: tourism, European practice, the development of tourism, types of tourism

Turizm digər ölkələrdə olduğu kimi Azərbaycan Respublikasında da təsərrüfat fəaliyyət zəncirinin əsas halqası rolunu oynamaqdadır. Çünki turizm əməktutumlu fəaliyyət növü kimi iqtisadiyyatın mikro və makro səviyyələrində gəlirliliyin vacib mənbəyi kimi çıxış edir. Xarici ticarət balansının müsbət istiqamətdə inkişafına öz töhfəsini verən turizm sektoru, ölkəmizdə ÜDMnin formalaşmasında da əvəzsiz paya sahibdir. Turizmin artan əhəmiyyətini anlayan dövlətimiz, bu sahəyə xüsusi qayğı ilə yanaşaraq 2010-cu ildə ilk dəfə turizm sektorunun sistematik inkişafi naminə dörd illik "Strateji Yol Xəritəsi" hazırlamışdır və bu gələcək yönümlü tədbirlər planı cənab Prezidentin 2016-c1 il 6 dekabr fərmanı ilə 2025-ci ilə qədər ediləcək işlərin və gediləcək inkişaf yolunun dəst-xətti təsdiq edilmişdir. Eyni zamanda biz tərəqqidən danışırıqsa, özümüzə nümunə kimi turizm sektorunda dünya ölçüsündə ciddi inkişaf yolu qətt etmiş ölkələrin təcrübələrindən yararlanmalıyıq ki, onların çatdığı səviyyəyə daha qısa zamanda ərə bilək.

Turizmdə öndə gedən ölkələrin siyahısına baxsaq burada ilk onluğun yarısını təmsil edən ölkələrin Avropa qitəsindən olduğunu görə bilərik. Avropanı bölən səddləri qaldırdıqdan sonra iqtisadi və sosial inkişafı birgə təmin etmək məqsədi ilə qurulan Avropa Birliyinə daxil olan ölkələr, bir yerə cəmlənərək, dünya turizminə 53\% pay sahibliyi edərək hakimlik göstərirlər.

Avropada turizm mədəniyyətinin formalaşmasındakı ilk ciddi addım 1984-cü ildə AB üzvü olmaq istəklərinin artması və AB regionun genişlənməsi artan tələbi nəzərə alaraq bu birlikdəki üzv ölkələr birləşərək turizm politikası çətirini formalaşdırdılar. 1990-cı ildə isə Avropa Turizm İli elan edilmişdir və ilk dəfə turizm AB maliyyə qaynaqlarından birbaşa dəstəklənəcəyi qeyd olunmuşdur. 1997-ci ildə ildə "PHILLOXNİA" başlığı altında bir proqrama başlanılmış və turizm vasitəsiylə Avropa daxilində inteqrasiyanın güclənməsi və iqtisadi-sosial inkişafın təmin olunacağ 1 vurğulanmışdır. Bu yolla da Avropada turizmin inkişafi üçün lazımi bütün zəminlər demək olar təmin olunmuşdur. Təklif edirik ki, birgə Avropada turizm inkişafına təkan olmuş səbəbləri incələyək.

Avropa turizm sektoru inkişafı dört əsas istiqamət üzrə fokslaşmışdır

- Turizmdə yeni texnologiyaların istifadəsi yolu ilə informasinın yayılmasını və paylanmasını tezləşdirmək 
- Turizm sektorunda keyfiyyəti qaldırmaq üçün ixtisaslı kadrların yetişəcəyi tədris ocaqlarının tərtibi və maliyyələşdirilməsi

-Turizm məhsullarının və xidmətlərinin keyfiyyətinin qaldırılması və ona nəzarət mexanizminin gücləndirilməsi

-Turizm inkişafının davamlı olması və genişləndirilməsi üçün geniş miqyaslı təbliğat və maliyyə dəstəkləri

AB turizmin inkişafındakı təməl prinsipin, böyümənin və inkişafin təmin edilməsinin əsas fəlsəfəsi rəqabəti daim üst səviyyədə saxlayaraq keyfiyyəti qaldırmaq və davamlı inkişafi təmin etməkdir. Qeyd olunduğu kimi ilkin təməl qayda turizm sektorunda rəqabətcil bazar qaydalarının hakimliyinin şəffaf şəkildə təmin edilməsi labüd haldır. Bu yolla oradakı müəssisələri yenilikçiyə, reklam və marketinq siyasətlərini genişlətməyə, xidmət və məhsulların keyfiyyətini və effektivliyini qaldırmağa təşviq etmək olar. Yəni bizim ilkin prioritet hədəfimiz Azərbaycan turizm bazarında liberal bazar dəyərlərinə sadiq qalacaq bir turizm mühiti formalaşdırmaqdır. Bu yolda önümüzdə duran əngəlləri zamanla aşmağı bacarmalıyıq. Bu yolda "ASAN Xidmət" agentliyinin yaradılması və "ASAN" visa rejiminin təmin olunması ideal addım idi. Lakin yetərli deyil. Gömrükdə malların daşınması zamanı qarşıya çıxan maneələr, vergi məsələlərində müəyyən güzəştlərin olunması, səhmdarların hüquqlarını bütövlükdə təhlükəsizliyinə zəmanət ilkin mərhələdə qarşımızda duran əsas hədəflər olduğunu düşünürük.

Ogər biz Avropa təcrübəsinin ölkəmizdə tətbiqini istəyiriksə, anlamalıyıq ki, turizmin ancaq bir neçə şəhərdə cəmləşməsinə meyl etməməli, digər şəhər və rayonlarda müəyyən qədər də olsa bu turizm imkanlarına dəstək olmalıyıq. Dövlət başçımızın təsdiqlədiyi 2025-ci il üçün olan turizm inkişaf proqramında da bu məqam vurğulanmışdır. Yəni turizmin Azərbaycanın digər regionlarında təbliği məsələsi gündəmə gəlməsinin əhəmiyyəti ön plana çəkilmişdir. Turizm elə bir sahədir ki, burada hisslər və xatirələr turistlərin geri gəlməsində əsas rol oynayır. Xalqımızın qonaqpərvərliyini nəzərə alsaq turizmin inkişafı üçün regionlarda münbit şərait yarada bilərik. Başlanğıc üçün ilk növbədə nəqliyyat infrastrukturu lazımi səviyyədə inkişaf etdirilməlidir. Kənd yollarımızın standartlara cavab verməməsi özünü regionlarımızda daha qabarıq şəkildə biruzə verir. Bu problemin həlli yolu ilə biz dünyada turizmin nisbətən cavan sahəsi olan və populyarlı̆̆ını günbəgün artıran sahəni "Ekoturizm - Kənd Turizmi" inkişaf etdirə bilərik. Bu turizmin əsas özəlliyi kənd əhalisinin turizm fəaliyyətində aktiv iştirakçı olmasını və turistlərə kənd həyatı yaşama imkanını təklif etməsindədir. Kəndlilər öz sahələrini kirayə və yaxud qonaqlıq kimi istifadəyə verərək turistlərə müəyyən müddətlik sağlam qidalanma və sağlam yaşamanı elə məhz təbiətin qoynunda reallaşdırma imkanı təklif edir. Bu yolla turistlər, xüsusən şəhər həyatından qaçmaq istəyən kütlə kənd həyatını görür və faydalanır. Bu sahənin vətənimizdə zəif inkişafının səbəblərini təxmin etmək olar. Nəqliyyat infrastrukturunun zəif olması xaricində, yerli əhalinin turizm anlayışı, xarici dil biliklərinin respublikamızda yetərincə yayılmaması, rayon bələdiyyələrində turizm inkişafı üçün tədbir və proqramların yetəri səviyyədə və lazımi keyfiyyətdə təşkil olunmaması və başqa səbəbləri sadalamaq olar. Bunun üçün bizim ilk növbədə edə biləcəyimiz turizm sahəsində ekspertlərin biliklərinə müraciət etmək və turizm sahəsində ixtisaslı kadrlar yetişdirən Turizm Universiteti ilə yaxından əməkdaşlıq şəklində kadrların regionlarda fəaliyyətinə şərait yaratmaq məqsədə uyğun olacaqdır.

AB-də yeni cərəyan halına gəlmiş digər bir turizm sahəsi olan Aqro-turizm Kənd turizmi ilə qarışdırılsa da burada məsələ biraz fərqli hal almışdır. Turistlərin fermer və əkin sahələrinə aparılması və orada müəyyən fəaliyyətlə təmin olunma və bu sahədə bilik bacarıqların praktiki öyrədilməsi bu sahənin xarakteristikası kimi bilinməkdədir. Avropa Kənd Təsərrüfatı və Qoruma Fondu (Guadince Section of the Eurpean Agriculture Guarantee and Guidance Fund) bu yeni turizm sahəsinin inkişafı və dəstəklənməsi üçün tədbirlər planını genişlətməkdədir. $\mathrm{Bu}$ sahənin də vətənimizdə inkişaf etdirilməsi arzuolunan olardı.

İndi növbə Avropa turizminin inkişafina səbəb olan əsas iki məsələ barədə bəhs etməkdədir.

-Turistlərin sərbəst gediş-gəlişinin təmin olunması (visa rejiminin yüngül olması)

-Səhmdarların maraqlarını təmin edərək onları cəlbetmə 
- Bildiyimiz kimi AB daxil olan ölkələrin ən böyük üstünlüklərindən biri, bəlkə də, birincisi "açıq qapı" kimi adlandırılan səyahət və ticarət imkanlarıdır. İnsanların əlavə viza əldə etmə kimi bir sıxıntısı olmadan, rahat bir şəkildə vahid Avropa vizası ilə $A B$ üzvü ölkələri sərbəst şəkildə səyahət etmə imkanları vardır. Bu amil təbii ki, müxtəlif xalqların inteqrasiyasını canlandırır, həmçinin millətlər arası irqi, dini mənsubiyyətlilik kimi fərqləndirici nüansların mənfi təsirlərini aradan qaldırmaqda böyük töhfə verir. Yaxın qonşularımızdan biri olan Gürcüstan 2014-cü ildə Avropa Birliyi ilə Assosiasiya Sazişi imzaladıqdan sonra Gürcüstan vətandaşlarının AB ölkələrinə səfərləri zamanı heç bir əlavə sənədləşmə proseduruna və viza tələbinə ehtiyac qalmadı. Bu Sazişin nəticəsi kimi Gürcüstana səfər edən illik xarici turist sayında cəmi 1.8 milyon artım qeydə alınmışdır (2014cü ildə 5milyon - 2017-ci ildə 6.8 milyon). Təbii olaraq bu artımın 80\% (təxminən 1.440 .000 turist) Avropadan gələn turistlərin payına düşür.

Hazırda 2021-ci il üçün AB və Azəraycan Respublikası arasındakı əlaqələrdə müsbət istiqamətdə addımların atılacağı proqnozlaşdırılır. Bu yolla biz həm xarici turist cəlb edə həm də xalqımızın turizm fəaliyyətini və həvəsini canlandıra bilərik. Bu yalnız xarici turist axını demək deyil. Bunun arxasında artan rəqabət gözləntiləri ilə birgə, yüksələn təlabata uyğun turizm xidmət və məhsullarında keyfiyyətin də yüksələcəyi proqnoz oluna bilər. $\mathrm{Bu}$ gedişat dolayısı ilə yerli marketinq siyasətinin daha geniş sahəni əhatə etməyə sövq edəcəkdir. Nəticədə "CNN", "The New York Times", "National Geographic" kimi nüfuzlu media agentliklərin ölkəmiz haqqinda reportajlarının artacağı labüddür. Nəhayət bu artan maraq ölkə turizm məkanına yeni oyunçuların daxil olmasına gətirib çıxaracaqdır. Söhbət xarici sərmayələrdən, xarici investorlardan gedir. Bu isə yuxarıda vacib bildiyimiz ikinci mərhələdir.

Xarici investorların ölkəyə gəlməsi üçün yalnız ölkəmizdəki turizm xidmətlərinə olan artan təlabət kifayət etməyəcəkdir. Lazım olan münbit şəraitin formalaşmasındakı digər şərt səhmdarların hüquqlarının lazımi şəkildə qorunmasının təminatıdır. Bu isə yerli bazarda fəaliyyət göstərən şirkətlərin maliyyə hesabatlarındakı şəffaflıqdan tutmuş, Dövlət Vergi orqanlarının işindəki dəqiqlik və qanunilik kimi amilləri əhəmiyyətinin artması deməkdir. Azərbaycandakı şirkətlərin və turizm müəssisələrin maliyyə hesabatlarının beynəlxalq standartlara uyğun hazırlanmaması (söhbət "IFRS - International Financial Reporting Standards" - larından gedir) xarici investorlardakı inamın itməsi ilə nəticələnir ki, bu isə turizm sektoruna potensial xarici valyuta axınının itirilməsi deməkdir. Dövlətimizin 2025-ci il üçün hazırlanmış inkişaf paketində bu məsələlərə yer ayırdığını görmək çox ümidverici haldır.

\section{Odəbiyyat}

1. "Azərbaycan Respublikasmda sosial-iqtisadi inkişafin sürətləndirilməsi tədbirləri haqqında" Azərbaycan Respublikası Prezidentinin fərmanı, Bakı, 24 noyabr, 2003

2. Azərbaycan Respublikasının “Turizm haqqında” Qanunu, (Bak1 27 iyul, 1999)

3. Dünya İqtisadi Forumunun Səyahət və Turizm Rəqabətqabiliyyətliliyi Hesabat1 2017

4. M.Y.Quliyev, Beynəlxalq ticarət sistemi qloballaşma fonunda// «Post-Bali goals of intemational trading system» konfransının materialları, TFİB, Bakı 2015, c.70-75

5. Məmmədov E.Q. “Turizmin inkişafının motivasiyası”, “Azərbaycan Aqrar Elmi №-4-5”, Bakı, 2007

6. ATEOLU, Levent (2006). Avrupa Birlii Turizm Politikası ve AB ile Türkiye Turizm Sektörlerine Etkileri

7. Neuts B., \& Nijkamp P. (2012). Tourist crowding perception and acceptability in cities: An applied modelling study on bruges. Annals of Tourism Research, 39(4), 2133-2153. doi: http://dx.doi. org/10.1016/j.annals.2012.07.016

8. Ünal, B.Aye (2007) Türkiyenin Avrupa Birli Turizm Politikasına Uyumu

9. Valentina Della Corte, Maura Scierelli, (2012): Destination management e logica sistemica: un confronto internazionale. (Destination management and systemic logic: International comparision.) G.Giapichelli Editore, Torino. 
TӘBİӘT ELMLӘRİ BÖLMӘSI

NATURAL SCIENCES SECTION

\author{
Türkanə Mirzəli qızı Oliyeva \\ AMEA Naxçıvan Bölməsi \\ dissertant \\ turanelizade_2016@mail.ru
}

\title{
KOMETLORIN TOTBIQ TARIXI
}

Açar sözlor: Günəş sistemi, səma mexanikası, göy cismi, komet, kometlarin dinamikası

\section{The history of the applications of comets \\ Summary}

In the presented work the date of application of comets is disscussed. The introduction provides extensive information about one of the most interesting members of the solar system comets. Comets consist of a spherical nucleus, a cloud around nucleus and a tail. The first written source about comets dates back to the third millenium BC and was found in ancient Chiense chronicles. The article notes that the development of spectroscopy and photometry led to significant work in field of comet physics. Thus, in the 19th century, about a few comets were found a year but thanks to the use of new observation devices, this number has now reached 30-35. The total number of comets currently observed has exceed 2,000. It is noted that when naming comets, comets whose orbits are inaccurate are referred to as X.

Key words: Solar system, celestial mechanics, celestial body, comet, dynamics of comets

Günəş sisteminin ən maraqlı üzvlərindən biri də kometlərdir. Komet yunanca kometos sözündən olub "quyruqlu ulduz" deməkdir. Günəş sisteminin əsrarəngiz və müəmmalı cisimləri olan kometlər ən qədim zamanlardan məlumdur. Ovvəllər güman edilir ki, kometlər atmosfer hadisəsidir.

Kometlər kürə şəkilli nüvədən, nüvə ətrafı buluddan və quyruqdan ibarətdir. Komet Günəşdən uzaqda olduqda o tutqun ləkə şəklində görünür. Günəşə yaxınlaşdıqca onun Günəşə tərəf çevrilən hissəsi q1zır, buxarlanır. İşı̆gın təzyiqi və Günəşdən gələn yüklü hissəciklərin təsiri ilə bu buxar Günəşdən əks tərəfə yönələn quyruğa çevrilir. Komet nüvələri kiçik meteor hissəcikləri toplusundan ibarətdir. Onun sıxlığı çox kiçik olub, Yer atmosferinin sıxlığından da kiçikdir. Kometlərin ölçüləri böyükdür. Bəzi komet nüvələri Yerdən də böyükdür. Lakin onların kütləsi Yerin kütləsindən milyon, hətta milyard dəfə kiçikdir.

Kometlər haqqında ilk yazılı mənbə eramızdan əvvəl III minilliyə aid olub, qədim Çin salnamələrində aşkar olunmuşdur. Belə məlumatlara qədim Babil, Misir, Yunan və başqa mənbələrdə də rast gəlmək mümkündür. Qeyd etmək yerinə düşərdi ki, Azərbaycan tarixçisi Z. Bünyadov qədim ərəb əlyazmaları üzərində tədqiqatlar apararaq, komet görüntüləri haqda bir çox dəyərli məlumatlar əldə etmişdir. Müqəddəs kitabımız “Qurani-Kərim”də kometlərlə bağl1lı̆g 1 ehtimal olunan bəzi işarələr mövcuddur (1).

Qədim avropalılar kometləri bədbəxtlik və ölüm carçısı kimi tanıyırdılar. İnsanlıq tarixi müharibələr, epidemiyalar, saray çəkişmələri, sui-qəsdlərlə dolu olduğu üçün, demək olar ki, hər bir kometin görünməsi bu faciəli hadisələrdən biri ilə üst-üstə düşür, insanlarda qorxu və dəhşət törədirdi. Eramızdan əvvəl 44-cü ildə Yuli Sezarın ölümü ilə üst-üstə düşən parlaq bir kometin görünməsi insanlarda bunların doğrudan da ölüm xəbərçisi olduğu fikrini yaratmışdı. Romalılar papa IV Urbanın ölüm səbəbini 1556-c1 il kometində görürdülər. İspaniya kralı V Karl bu kometin onu ölümlə hədələdiyinə əmin idi. O hətta bu kometə tapançadan atəş də açmışdı. 
- Qədim çinlilər, avropalılardan fərqli olaraq kometləri ulduzlar arasında məlumat daşıyan, elçi hesab edirdilər. Onların fikrincə, Göy böyük bir ölkə, ulduzlar isə hökmdarın yerli hakimləri idilər. Kometlər Göydə gəzişərək hökmdarın əmrlərini yerli hakimlərə çatdırırdılar. Çinli astronomlar hər bir kometin meydana çıxmasını və yox olmasını, həmçinin ulduzlar arasında yerdəyişməsini, avropalılardan fərqli olaraq çox dəqiq qeydə alır, ətraflı təsvir edirdilər.

XVII əsrin ikinci yarısında polşalı astronom Yan Qeveliy kometlər haqqında bütün mümkün materialları toplayıb "Kometoqrafiya" (1668) adlı kitabını nəşr etdirdi. Təxminən, yüz il sonra Paris universitetinin keşişi A.Prinqe ikicildlik eyniadlı əsərini çap etdirdi. Bu əsər elmi cəhətdən daha maraqlı idi. Belə ki, burada 837-ci il və 1456-c1 il kometlərinin eyni bir komet olduğu kifayət qədər dəqiq əsaslandırılmışdı. Belə əsaslı kometoqrafiyaların olmasına baxmayaraq, keçmiş kometlər haqq1ndakı məlumatlar son dərəcə natamam və səthi idi. 1871-ci ildə ingilis alimi Vilyams kometlər haqqında fransız missionerləri tərəfindən toplanmış qədim Çin salnamələrini çap etdirdi.

XVII - XVIII əsrlərdə İ.Nyuton, E. Halley səma mexanikasının inkişafina öz tədqiqatları ilə güclü təkan verdilər və komet dinamikasının əsasını qoydular. Səma mexanikasının metodları komet tədqiqatı sahəsində mühüm nəticələr almağa imkan verdi. Bir sıra elm adamları: Laplas, Laqranj, Leverye, Tisseran, Şulqoff və başqaları komet kosmoqoniyası sahəsində böyük işlər gördülər (2).

XVIII əsrin sonu, XIX əsrin əvvəllərində səma mexanikası elmi yüksək dərəcədə inkişaf etmişdi. Belə ki, Uranın kəşfindən sonra onun məruz qaldığı sarsıntılara əsaslanaraq, fransız alimi Leverye və ingilis alimi Adams biri-birindən asılı olmadan, sonradan Neptun adlandirılacaq planetin yerini nəzəri olaraq hesabladılar. 23 sentyabr 1846-c1 ildə alman astronomu Halley həmin planeti Leveryenin verdiyi koordinatlarda müşahidə etdi. Neptunun kəşfindən sonra elmi tədqiqat işləri daha da vüsət aldı. Laplas və Laqranj kometlərin mənşəyinə dair biri-biri ilə ziddiyət təşkil edən iki müxtəlif hipotez irəli sürərək, komet kosmoqoniyasının əsasını qoydular. Tisseran Yakobi inteqralından istifadə edib, kometlərin fərqləndirilməsi üçün yeni kriteriyasını verdi. Nyuton, Şulqoff və başqaları Laplas nəzəriyyəsini inkişaf etdirərək qiymətli nəticələr əldə etdilər.

Bəs kometlər Günəş sisteminə haradan gəlir? Kometlərin mənşəyi barədə bu günə qədər qızğın mübahisələr aparılsa da, bu məsələ hələ ki, konkret həllini tapmayıb. Hələ XVIII əsrdə Herşel, kometləri ulduzlararası fəzada hərəkət edən kiçik dumanlıqlara bənzədirdi.

1796-c1 ildə Laplas kometlərin mənşəyi barədə ilk elmi hipotez irəli sürdü. O, kometləri ulduzlararası dumanlıqların qırıntıların hesab edirdi. Kometlərin kimyəvi tərkibcə müxtəlif olması bunu inkar etsə də, parabolaya yaxın orbitlərin mövcudluğu bunu təsdiq edirdi. Laplasa görə həm uzundövrlü, həm də q1sadövrlü kometlər ulduzlararası mənşəlidirlər. Q1sadövrlü kometlər isə sonradanYupiter tərəfindən zəbt edilərək q1sadövrlü orbitlərə keçirilmişlər. Bu hipotezin indiki dövrdə də bəzi tərəfdarları vardır. Laplasın “zəbtetmə” hipotezindəki bir sıra çətinliklər kometlərin mənşəyi haqda fikirlər söyləməyə sövq edirdi.

XX əsrin ortalarında holland astronomu Y.Oort digər bir hipotez irəli sürdü. Bu hipotezə görə, nə vaxtsa Yupiter və Marsın orbitləri arasında mövcud olan Faeton adlı hipotetik bir planetin partlaması nəticəsində Günəşdən təqribən 150000 a.v. məsafədə komet buludları əmələ gəlmişdir. Yaxın ulduzların təsiri altında bəzi kometlər buradan ayrılaraq, Günəş sisteminə daxil olur və müşahidə obyektinə çevrilirlər. Akademik V.Q.Fesenkovun fikrincə, Faetonun partlamasına səbəb, onun Yupiterlə çox yaxınlaşması nəticəsində yüksək dərəcədə q1zması olmuşdur. Van Flandern 60 uzundövrlü kometin orbit elementləri üzərində tədqiqat apararaq, belə nəticəyə gəlir ki, 5 milyon il əvvəl Yupiter və Marsın orbitləri arasında kütləcə Saturna bərabər bir planet partlamışdır (3). Belə partlayış nəticəsində maddənin bir hissəsi Faetonun əvvəlki orbitində hazırda asteroid, komet və meteorit nüvələri şəklində dövr etməkdədir, çox hissəsi isə Günəş sisteminin sərhədlərini tərk edərək onun ətrafında toplanmış və Oort buludlarını əmələ gətirmişdir. Səma mexanikası metodlarının tətbiqi ilə aparılan araşdırmalar göstərir ki, Oort buludlarını mövcuddur və kifayət qədər dayanıqlidır.

XIX əsrdə kometlərin dinamikası ilə yanaşı fizikası sahəsində də müəyyən işlər görülməkdə idi. $\mathrm{Bu}$ zaman kometin nüvəsi, atmosferi, quyruğun əmələ gəlməsi mexanizmi barədə ilk təsəvvürlər mövcud idi. XIX əsrin sonlarına yaxın tədqiqatçı alimlərdən Bredixin, Orlov və başqaları komet 
fizìkası sahəsində xeyli işlər görmüşdülər. Bredixin komet quyruqlarının təsnifatını vermiş. Yaranma və inkişaf mexanizmini göstərmişdir. Olbersin və Besselin komet fizikası sahəsində işləri diqqətəlayiqdir. XIX əsr komet fizikasına aid tədqiqatlar Şulmanın monoqrafiyasında geniş şərhini tapib.

Spektroskopiyanın və fotometriyanın inkişafı komet fizikası sahəsində mühüm işlərin görülməsinə səbəb oldu. Rus astrofiziki Vsexsvyatski komet fizikası ilə bağlı xeyli dəyərli nəticələr əldə etdi. 1949-cu ildə Uipl komet nüvəni nəzəriyyəsini verdi. Bu nəzəriyyəyə görə komet nüvələri müxtəlif mineralların buzla qarışığından ibarətdir. Oxşar ideya əvvəllər Vsexsvyatski tərəfindən də söylənmişdir. Komet nüvəsinin təkamülü sahəsində Şulmanın gördüyü işlər xüsusi qeyd olunmalıdir.

XIX əsrdə, ildə təqribən bir neçə komet tapılırdırsa, yeni müşahidə cihazlarının tətbiqi sayəsində bu say hazırda 30-35-ə çatmışdır. 2008-ci ildə qısadövrlü kometlərin sayı 300-ü, uzundövrlülərinki isə 900-ü ötmüşdür. Periheli məsafələri çox kiçik olan "Kreyts qrupu" adı ilə tanınmış 1000-dən artıq "kamikadze kometlər" adlanan xüsusi xarakteristikalı komet qrupu məlumdur. "Kreyts qrupu" kometlərinin nə vaxtsa parçalanmış iri bir komet nüvəsindən əmələ gəldikləri ehtimal olunur. Bu qrupa məxsus olan kometlər perihelidə Günəşə çox yaxınlaşdıqları üçün, bəzən Günəş tərəfindən tutulur və məhv edilirlər.

Avropa kosmik agentliyinin GİOTTO süni peyki 1986-c1 ilin mart ayında Halley, 1992-ci ildə isə Qriqq-Skellerup kometini tədqiq etmişdir. Yapon süni peykiləri SAQIQAK və SUYSEY 1986c1 ildə Halley kometinə yaxınlaşaraq onun atmosferini öyrənmişlər. Kometlərin kosmik tədqiqi sahəsində ən cəsarətli proqram “Deep İmpakt" olmuşdur. Proqrama əsasən, 2005-ci ildə buraxılan avtomat stansiya Tempel-1 kometinə yaxınlaşaraq onun nüvəsinə zərbə yendirməli və nüvədən material götürməli idi. 4iyul 2005-ci ildə "İmpaktor" $10.3 \mathrm{~km} / \mathrm{san}$ sürətlə kometin nüvəsinə zərbə yendirdi. Zərbə nəticəsində güclü partlayış baş verdi, $370 \mathrm{kq}$ ağırlığında olan aparat qaz-toz dumanına çevrildi. "Deep İmpakt" özü məhv olsa da, xeyli dəyərli məlumatları və fotoşəkilləri yerə ötürə bildi. Kometə gəldikdə isə, onun səthindən zərbə nəticəsində qopan maddə xeyli yüksəyə atıldı. Bu hadisə gözlənildiyinin əksinə olaraq çox güclü parıltı ilə müşayiət olundu. Atılmış material yalnız 12 saatdan sonra dağılıb yox oldu. Toqquşmanın müşahidəsindən alınan məlumatların analizi göstərdi ki, kometin üst qatını təşkil edən maddə nəzərdə tutulandan tamamilə fərqlənir (4).

Komet nüvəsi barədə bütün mövcud olan informasiyaları cəmləşdirmək məqsədi güdən tədqiqatçılar məhşur Tunqussk "meteoriti”ni yada salmalı oldular. Məsələ bundadır ki, 1975-ci ildə rus alimləri Q.İ.Petrov və V.P.Stulov belə nəticəyə gəlmişdilər ki, 1908-ci ildə Sibirin Tunqussk rayonunda partlayan göy cisminin sıxlığı, adi suyun sıxlığından 100 dəfə kiçik olub, $10 \mathrm{mq} / \mathrm{sm}^{3}$ dən böyük deyil, diametri isə 300 metrə çatırmış. Alınmış belə nəticəyə inanmaq istəmirdilər. Təsəvvür etmək mümkün deyildi ki, belə seyrək maddədən təşkil olunmuş bir cisim bütünlüyünü necə saxlayıb və Yer səthində partlayaraq 3000 kv.km meşə ərazisini məhv edib, 97 il sonra "İmpaktor"un Tempel-1 kometi ilə toqquşması zamanı alınan nəticələr, rus alimlərinin aldığı nəticələri təsdiq etdi.

Beləliklə, Tunqusskda nə baş vermişdir? 1927-ci ildən başlayaraq aparılan çoxsaylı tədqiqatlar zamanı hadisə yerində kosmik mənşəli heç nə tapılmadı. 1949-cu ildə tədqiqatç1lar belə nəticəyə gəldilər ki, partlayışı törədən əsasən buz və toz qarışı̆̆ından ibarət kiçik komet nüvəsi olmuşdur. Partlayış zamanı nüvə tamamilə buxarlanaraq yox olmuş və törətdiyi dağıntılardan başqa heç bir iz qoymamışdır. $\mathrm{Bu}$ kosmik cismin hərəkət trayektoriyasının öyrənilməsi göstərdi ki, o Enke kometinin parçalanmasından alınan Beta-Taurid meteorit selinin orbiti ilə hərəkət edirmiş.

Yuxarıda qeyd olunduğu kimi hazırda müşahidə olunmuş kometlərin sayı 2000-i ötmüşdür. Ovvəllər kəşf olunan yeni kometə müəllifin adı verilir və eyni zamanda tapıldığı ilə və sırasına görə nömrələmək qəbul olunmuşdu. Belə qayda o qədər də münasib deyildi. Bu zaman kometin dövrü olub-olmamas1, əgər dövrüdürsə, neçənci dəfə müşahidə olunduğu barədə heç nə məlum olmurdu. 1990-c1 illərin ortalarından yeni qayda tətbiq olundu. Məsələn: C/2005 A1. Burada 2005-kometin 
tap̀ılma ilini, A1-uyğun ayın ilk 15 günü, C -uzundövrlü olduğunu göstərir. Ogər komet q1sadövrlüdürsə, $\mathrm{C}$ əvəzinə $\mathrm{P}$ yazılır. Orbitləri dəqiq olmayan kometlər $\mathrm{X}$ kimi işarə olunur.

\section{Odəbiyyat}

1. Hüseynov R., Ümumi astrofizika, Bak1, 2010, s. 368.

2. Мартынов А. Я., Курс практической астрофизики, Москва, 1971, с. 541.

3. Бронштэн В. А., Планеты и их наблюдение, Москва, 1957, с. 206.

4. Андрианов Н.К., Марленский А.Д., Астрономические наблюдения в школе, Москва, 1987, с. 109. 


\section{ZIQOMISETLORIN FERMENTATIV AKTIVLIYI

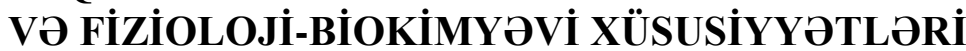

Açar sözlor: Ziqomisetlar, metabolitlar, Rhizopus Oryzae, fermentlar, Mucor

\section{Energy activity and physiological - biochemical features of zygomysets Summary}

In the presented article discusses the study of the enzymatic activity and other physiological and biochemical properties of zygomycetes. Mushrooms in this class contain enzymes that act as catalysts. These enzymes are used in the biological treatment of soils contaminated with various organic substances and in the creation of new sustainable products. In the preparation of fermented foods, industrial metabolites, a large number of raw materials are produced with the help of lactic acid, fumaric acid and ethanol from enzymes that are part of zygomycetes. Fungi belonging to the class Zygomycetes produce enzymes that facilitate the assimilation of various species. The enzymes produced play an important role in the catalysis of various reactions. The biomass produced consists of amino acid containing proteins, lipids and chitosan with the help of zygomycetes.

Key words: Zygomycetes, metabolites, Rhizopus Oryzae, enzymes, Mucor

\section{Giriş}

Ziqomisetlər sinfi göbələklərin Ziqomikota (lat. Zygomycota) şöbəsinə daxildir. Ziqomisetlər sinfinə Zygomycota şöbəsinin böyük əksəriyyət nümayəndələri daxildir. Ziqomisetlər 1300-dən çox göbələk növünü qruplaşdıran bir parafiletik qrupdur. Bu sinif Mucorales, Endogonales, Entomophthorales, Zoopagales sıralarını özündə birləşdirir. Ziqomisetlər ən böyük ekoloji müxtəlifliyə sahib göbələklər qrupudur. Ziqomisetlər sinfinə aid olan göbələklər torpaqda, bitki qalıqlarında, peyində, qida məhsullarında saprotrof həyat tərzi keçirirlər. (Şəkil 1)

Meyvə, torpaq və gübrə kimi substratlarda saprofitlər, heyvanların daxili orqanlarındakı simbiozlar, mikorizalar əmələ gətirən bitkilərdəki və heyvanların, bitkilərin, həşəratların və digər göbələklərin patogenləri ola bilər. Ziqomisetlər göbələklərin vacib bir sinfidir və onlardan sənaye fermentasiyasında istifadə olunur. Təxminən yüz il bundan əvvəl soya əsaslı və amilaza mənşəli qidaların bu göbələklər tərəfindən istehsal olunduğu müəyyən olunmuşdur.

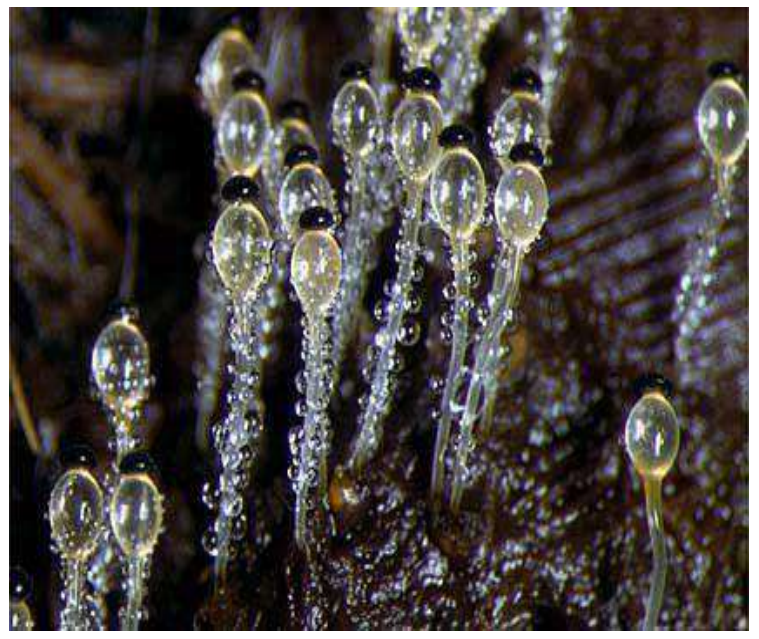

Şəkil 1 
- Qida fermentasiyasından qədim dövrlərdən müasir dövrümüzədək istifadə edilir. Qida fermentasiyasında, müxtəlif üzvi maddələrlə çirklənmiş torpaqların fermentasiyasında ziqomisetlərin Rhizopus, Amylomyces, Actinomucor, Mucor, Chaetostylum və.s. nümayəndələri iştirak edir. Bəzi hallarda isə Ziqomisetlər (Zygomycetes), Aspergillus və Neurospora ilə birlikdə istifadə edilə bilər. Yeyinti sənayesində qidanın mayalanmasında ziqomisetlərin mucorales sırasının cinslərindən istifadə olunur. Rhizopus Oryzae cinsindən, Asiya və Afrikada alkoqollu içkilərin istehsalı üçün istifadə olunur. Ziqomiset göbələklərin müxtəlif və genişlənən məhsullarla istifadəsi bu inkişafa əhəmiyyət qatmışdır.

Dünyada ziqomisetlərə ölü üzvi maddələr üzərində böyüyən saprofit kimi rast gəlinir. Ziqomisetlər uzun müddətdir qida istehsalında istifadə olunur. Üzvi turşuların istehsalı üçün ziqomisetlərin Rhizopus cinsindən, etanol istehsalı üçün Mucor cinsindən istifadə olunur. Bu tip göbələklərin əksəriyyəti saprofitdir. Parazit növləri də mövcuddur. Cansız üzvi maddələri parçalamaq qabiliyyətinə malikdirlər. Bəzi saprofitlər mühüm sənaye məhsullarının sintezində iştirak edirlər. Bunlardan nişastadan spirt almaq üçün sənayedə istifadə olunur.

Dünyada əhali artımı neft, qlobal istiləşmə və getdikcə artan tullantıların miqdarı, çirklənmiş torpaq sahələrinin artmasına səbəb olur, bu da torpaqların bioloji aktivliklərinə mənfi təsir göstərir.

Qeyd edək ki, bu zaman çirkləndirici üzvi maddələrin torpağa düşməsi nəticəsində mühüm bioloji proseslərdə iştirak edən fermentlərin aktivliyində kəskin dəyişikliklər baş verir.

Göbələklər və o cümlədən ziqomisetlər torpaqda fermentlərin əmələ gəlməsinin başlica mənbəyi hesab olunur. Müxtəlif istehsal prosesləri nəticəsində əmələ gələn tullantıların, o cümlədən neft, neft məhsulları, bitki mənşəli maddələrin mikrobioloji, yaxud enzimoloji yolla effektiv şəkildə parçalanması, həm mikrobioloji, həm də enzimoloji bir məsələdir. Bu nöqteyi-nəzərdən göbələklər yüksək bioloji fəallığa malikdirlər və onlar bu və ya digər fermentin aktiv produsenti kimi mühüm əhəmiyyət kəsb edirlər.

Torpaqlarda çirkləndiricilərin yı̆̆ılması təkcə torpağın məhsuldarlığı və ekosistem funksiyalarına deyil, həm də qida zənciri vasitəsi ilə heyvan və insan sağlamlığına mühüm təsir göstərir. Neftlə çirklənmiş torpaqların regenerasiya prosesində, peroksidaza, dehidrogenaza, katalaza və bir sıra hidrolaza fermentləri mühüm rol oynayırlar.

Qeyd edək ki, göbələklər tərəfindən torpaq mühitinə ifraz olunan fermentlər torpaqda olan biokütlənin deqradasiyasını kataliz etməklə torpağın müdafiə qabiliyyətini artırmış olur.

Neftlə çirklənmiş torpaqlarda məskunlaşan göbələklərin o cümlədən ziqomisetlərin həyati fəaliyyəti nəticəsində torpağa sekresiya etdikləri fermentlər, bioloji katalizatorlar hesab olunurlar. $\mathrm{Bu}$ fermentlər torpağın humus qatının sintezi və parçalanması, üzvi birləşmələrin hidrolizi və $\mathrm{s}$. mühüm biokimyəvi proseslərdə fəal iştirak edirlər.

Ziqomisetlər tərəfindən sekresiya olunan fermentlər bitki-heyvan mənşəli qalıqların parçalanmasında və mənimsənilə bilən formaya salınmasında, mühüm rol oynayırlar.

Çirklənmənin qarşısını almaq və ətraf mühitin çirkləndiricilərini parçalamaq üçün ziqomisetlərin istifadəsinə əsaslanan mikoremediasiya, ətraf mühitin çirklənməsinin aradan qaldırılması və qarşısının alınmasında təsirli bir biotexnoloji yanaşma kimi əhəmiyyət qazanır.

Mikoremediasiya çox faydalı üsuldur, çünki digər metodlarla müqayisədə təbii olaraq meydana gələn və qənaətli bir üsuldur. Göbələklər tərəfindən torpağa sekresiya olunan peroksidaza fermenti, liqnin kimi heteropolimerlərin, fenolların, aminlərin və s. üzvi qalıqların oksidləşməsi prosesini kataliz edirlər.

Mikoremediasiya, bərpa üçün ən ucuz həllərdən biridir və ümumiyyətlə baha avadanlıq tələb etmir.

\section{Noticə}

Mərkəzi katalizator kimi ziqomisetlərlə qida sənayesində və torpaqdan çirkləndirici maddəllərin alınması perspektivlidir.

Ümumilikdə ziqomisetlərdən, fermentlər istehsalı üçün potensial, qida məqsədləri üçün göbələk biokütləsi və lipidlər alınır. Beləliklə, üzvi çirkləndiricilərin təmizlənilməsində, mikoremediasiya 
pròsesində və qida sənayesində fermentasiya prosesində ziqomisetlər sinfi çox mühüm rol oynayır.

Habelə, onlardan qida fermentasiyasında spirtli içkilərində alınmasında belə istifadə olunur. Ziqomisetlər torpaqda zülal və digər azotlu birləşmələrin bitki və heyvan mənşəli birləşmələrin parçalanmasında yaxından iştirak edirlər.

\section{Odəbiyyat}

1. İbrahimov A.Ş, İbtidai bitkilər, Bakı Universiteti nəşriyyatı 1993.

2. S.M.Cəbrayılzadə. Mikologiya, ADPU nəşriyyatı, Bakı - 2011, 336

3. A.Ş.İbrahimov, Z.A.Abdulova, L.N.Mehdiyeva. Mikologiya, «Bakı Universiteti» nəşriyyatı, 2008, 324 səh.

4. Namazov N.R. Göbələklər və göbələyəbənzər canlılar aləmi. Sumqayıt 2019, 471 s.

5. Мюллер Э, Лёффлер В, Микология 1995, 343 с

6. Микология: грибы и грибоподобные организмы: учеб. пособие / Перм. гос. ун-т. Пермь, 2009. - 199 с 


\section{DəQİQ ELMLӘR BÖLMӘSI}

EXACT SCIENCES SECTION

Xumar Tofiq qizı Novruzova Bak1 Slavyan Universiteti dosent novruzovaxumar@gmail.com

\section{QEYRI-MÜəYYON TəNLIKLəR}

Açar sözlor: diofant, tənlik, riyaziyyat, məsəla, xətti

\section{Indeterminate equations Summary}

This article shows how you can find the solutions to linear Diophantine equation. The study of Number Theory here in this article aims to study some properties of integer multiples or divisors, emphasizing issues related to divisibility, which will be of great importance for the study of Diophantine equation. A Diophantine equation is an equation in which only integer solutions are allowed. We use a variation of the Euclidean algorithm to find the general solution of a linear Diophantine. This work is intended to further training of teachers who are teaching in the elementary and high school. You can find suggestions for activities that you can apply in the classroom, or even include in your lesson plan Diophantine equations. The problem of determining all the solutions of a linear Diophantine equation has been completely solved.

Key words: diophantine, equation, mathematics, task, linear

\section{Giriş}

Məlumdur ki, şəxsiyyətyönümlü kurikulumun əsas tələbi - praktik bilik və bacarıqların önə çəkilməsidir. Bu səbəbdən məktəb riyaziyyat kursunda həll edilən məsələlər şagirdlərin praktik fəaliyyətinə, həyat və məişətinə uyğun olmalı, onlarda analiz, sintez, müqayisə kimi təfəkkür əməliyyatlarını inkişaf etdirməlidir. Belə məsələlərin bir qismi qədim isgəndəriyyəli alim Diofantın adı ilə bağlı olan Diofant tənliklər vasitəsilə həll edilir. Ona görə də riyaziyyat dərslərində bu tənliklərin həlli üsullarını araşdırmaq və onların məsələ həllində tətbiqlərini göstərmək şagirdlər və gələcək peşələrində riyaziyyat müəllimliyi ixtisasını seçən tələbələr üçün çox vacibdir.

Qeyri-müəyyən tənliklər - birdən artıq məchulu olan tənliklərdir. Başqa sözlə, məchulların sayı tənliklərin sayından çox olduqda, belə tənliklərə qeyri-müəyyən tənliklər deyilir.

Tərif. Bir dərəcəli n məchullu Diofant tənlik

$$
a_{1} x_{1}+a_{2} x_{2}+\ldots+a_{n} x_{n}=b
$$

şəklində olan tənliklərə deyilir. ( $\left.\mathrm{a}_{\mathrm{i}} \neq 0\right)$. (https://mathworld.wolfram.com)

Bir çox hallarda Diofant tənliklər tam ədədlər çoxluğunda, bəzən isə natural ədədlər çoxluğunda həll edilir.

Tərif. (1) tənliyinin həlli elə $\mathrm{x}_{1}, \mathrm{x}_{2}, \ldots . \mathrm{x}_{\mathrm{n}}$ tam ədədlərinə deyilir ki, bu ədədlər (1)-i ödəsin.

İki $x$ və y dəyişənindən asılı xətti Diofant tənlik $a x+b y=c(a, b, c \in Z)$ şəklindədir.

Diofant III əsrdə yaşamış qədim İsgəndəriyyə alimidir. Onun həyatı haqqında bizə çox cüzi məlumat gəlib çatmışdır. Məsələn, başqa bir yunan alimi Metrodor (VI əsrdə yaşamışdır) onun qəbir daş1 üzərində aşağıdakı məsələni vermişdir: «Diofant ömrünün 1/6-ni uşaqlıqda, 1/12-ni gənclikdə, 1/7-ni isə subaylıqda keçirmişdir. O, evləndikdən 5 il sonra bir oğlu olmuş, atasının 
yaş̀ının yarısı qədər ömür sürüb ölmüşdür. Oğlundan 4 il sonra Diofant özü ölmüşdür. Diofant neşə il yaşamışdı?" Bu şərtlərə uyğun tənlik qursaq, alarıq:

$$
\begin{aligned}
& \frac{x}{6}+\frac{x}{12}+\frac{x}{7}+5+\frac{x}{2}+4=x \\
& 14 x+7 x+12 x+420+42 x+336=84 x \\
& 9 x=756 \\
& x=84
\end{aligned}
$$

Deməli, Diofant 84 il yaşamışdır.

Diofant "Hesab" adlı 13 cildddən ibarət kitab yazmış, lakin bu kitabların yalnız 6-sı bizə qədər gəlib çatmışdır. Diofanta qədər iki cür qeyri-müəyyən tənlik məlum idi.

$$
\mathrm{x}^{2}+\mathrm{y}^{2}=\mathrm{z}^{2} \quad \mathrm{x}^{2}-a \mathrm{y}^{2}=1
$$

Birinci tənlik qədim babillilər tərəfindən həll edimişdir. Tənlik pifaqorçular tərəfindən aşağıdakı kimi həll edilmișdir:

$$
\begin{aligned}
& \mathrm{x}=\mathrm{k}^{2}-1 \\
& \mathrm{y}=2 \mathrm{k} \\
& \mathrm{z}=\mathrm{k}^{2}+1
\end{aligned}
$$

k-ya $1,2,3, \ldots$ və s. natural qiymətləri verərək, tənliyin köklərini tapa bilərik.

$\mathrm{k}=1$ olduqda $\mathrm{x}=0, \mathrm{y}=2, \mathrm{z}=2$,

$\mathrm{k}=2$ olduqda $\mathrm{x}=3, \mathrm{y}=4, \mathrm{z}=5$

$k=3$ olduqda $x=8, y=6, z=10$ və $s$.

İkinci tənlik Evklidin "Osaslar” kitabında tam ədədlər üçün həll edilmişdir.

Diofant "Hesab" kitabının II cildində müxtəlif növ qeyri-müəyyən tənliklərin həllinə baxmışdır və aşağıdakı teoremi isbat etmişdir:

Teorem. II tərtib qeyri-müəyyən tənliklərin ya heç rasional həlli yoxdur, ya da aşağıdak1 rasional funksiyalarla tapılan sonsuz sayda həlli var. (Степанов, 1984: 31)

$$
x=\varphi t, y=\omega(t)
$$

Diofantın tənliklər nəzəriyyəsi sonrakı dövrlərdə böyük sürətlə inkişaf etməyə başladı. XVII əsrdə fransız alimi Başe de Mezirak birinci dərəcəli Diofant tənliklərinin həlli üçün ümumi üsul yaratdı. XVI-XVIII əsrlər müddətində alimlərdən P.Ferma, C.Vallis, L.Eyler, J.Laqranj və K.Qauss əsasən aşağıdakı şəkildə tənlikləri tədqiq etdilər: (Степанов, 1984: 33)

burada a, b, c, d, f tam ədədlərdir.

$$
a x^{2}+b x y+c y^{2}+d x+c y+f=0
$$

XX əsrdə tam əmsallı ixtiyari dərəcəli iki məchullu tənlikləri Norveç riyaziyyatçısı A.Tue araşdırmış və isbat etmişdir ki, belə tənliklərin sonsuz sayda tam həlləri ola bilməz. Bəs onda onların həlləri sayı neçədir və hansı sərhəd daxilindədir? - bu suala cavab tapılmadı. Nəhayət, B.N. Delone (1890) qeyri-müəyyən tənlikləri araşdıraraq, onların həllər sayının sərhədini təyin edən maraqlı bir üsul tapdı. Delone metodu ilə xüsusi halda aşağıdakı şəkildə tənliklər tam həll olunur: (Матиясевич, 1972: 189)

Misala baxaq.

$$
\begin{aligned}
& \mathrm{ax}^{3}+\mathrm{ty}^{3}=1 \\
& 4,5 \mathrm{x}+6 \mathrm{y}=57 \quad(\mathrm{x}, \mathrm{y} \in \mathrm{N}) \\
& 9 \mathrm{x}+12 \mathrm{y}=114 \\
& \mathrm{y}=\frac{114-9 x}{12}
\end{aligned}
$$

Seçmə üsulundan istifadə edək - 114-dən 9-a bölünən hansı ədədi ç1xa bilərik ki, alınan fərq 12yə bölünsün? 12-yə bölünən ədədlər 12, 24, 36, 48, 96 və s.-dir. Bu şərti ödəyən ədədlər isə 18 və 90 ədədləridir.

Aşağıdakı təklifləri qeyd edək.

$$
\begin{aligned}
& x=2, \quad y=8 \\
& x=10, \quad y=2
\end{aligned}
$$

$\mathrm{ax}+\mathrm{by}=\mathrm{c}$ tənliyi üçün: (a, b, c -tam ədədlərdir)

1) a və b qarşılıqlı sadə ədədlərdirsə, $a x+b y=1$ tənliyinin ən azı bir tam kökü var. $x=x_{0}+b k$, $\mathrm{y}=\mathrm{y}_{0}+$ bk. $\left(\left(\mathrm{x}_{0}, \mathrm{y}_{0}\right)\right.$-hər hansı bir həlldir $)$ 
2) Ogər (a, b)=d olarsa, c $\vdots$ d olduqda həll var, $c \vdots d$ olduqda isə həll yoxdur.

Diofant tənliklər vasitəsilə həll edilən bir neçə məsələyə baxaq.

1.Alıcı mağazadan 21 manat məbləğində mal aldı. Onun yalnız 5 manatlıq, kassirin isə 3 manatlıq pulları var idi. $\mathrm{O}$, kassirlə bu pullarla hesablaşa bilərmi?

Həlli. $5 \mathrm{x}-3 \mathrm{y}=21$

$$
\begin{gathered}
3 y=5 x-21 \\
y=\frac{5}{3} x-7=x+\frac{2}{3} x-7 \\
\frac{2}{3} x=t \\
x=\frac{3}{2} t \\
y=\frac{3 t}{2}-7+t=\frac{5}{2} t-7 \\
\frac{5}{2} t-7>0 \\
t>\frac{14}{5}=2,8
\end{gathered}
$$

\begin{tabular}{|c|c|c|c|}
\hline $\mathrm{t}$ & 4 & 6 & 8 \\
\hline $\mathrm{x}$ & 6 & 9 & 12 \\
\hline $\mathrm{y}$ & 3 & 8 & 13 \\
\hline
\end{tabular}

2. Yaşayış evinin təbii qazla təmin edilməsi üçün $150 \mathrm{~m}$ uzunluğunda qaz borusu çəkmək lazımdır. Boruların $13 \mathrm{~m}$ və $9 \mathrm{~m}$ uzunluqda olduqları məlumdursa, bu boruların hərəsindən neçəsini götürmək lazımdır ki, itki olmadan qaz borusu çəkilsin.

Həlli. Tutaq ki, 9m uzunluqda $\mathrm{x}$ dənə, 13m uzunluqda isə y dənə boru götürmək lazımdır. $9 \mathrm{x}+13 \mathrm{y}=150$

OBOB $(9,13)=1$ olduğundan tənliyin tam ədədlər çoxluğunda həlli var.

$$
x=\frac{150-13 y}{9}
$$

Burada 150-13y ifadəsinin 9-a tam bölünməsi üçün y dəyişəninə qiymətlər verib yoxlasaq alariq: $150-13 \cdot 6=72$

Onda 13 m-lik 6 boru, 9 m-lik 72:9=8 boru götürmək lazımdır.

3. Arif kafedə ofisiant işləyir. Ona hər iş saatı üçün 10 man. pul verilir, hər sınan qab üçün 2 man. pul çıxılır. Keçən həftə ərzində onun həftəlik qazanc1 180 manat oldu. Gün ərzində onun 3 saatdan çox işləmədiyini bilərək, Arifin həftə ərzində neçə saat işlədiyini və neçə qab sındırdığını tapin.

Həlli. Tutaq ki, həftə ərzində Arif x saat işləyib. Onda o, 10x manat pul qazanmalı idi. Lakin əgər y sayda qab sındırıbsa, onun pulundan $2 \mathrm{y}$ manat kəsilib. Onda aşağıdakı tənliyi alarıq:

$10 \mathrm{x}-2 \mathrm{y}=180$

$$
\begin{gathered}
5 \mathrm{x}-\mathrm{y}=90 \\
\mathrm{x}=\frac{\mathrm{y}+90}{5}
\end{gathered}
$$

x-in tam ədəd olduğunu nəzərə alsaq, onda y 5-ə tam bölünən ədəd olmalıdır. Burada 4 hal ola bilər:
1) $y=0, x=18$
2) $y=5, x=19$
3) $y=10, x=20$
4) $y=15, x=214$.

İdmançılar üçün 24 və 17 yerlik avtobuslar sifariş edildi. 24 yerlik avtobuslarda əyləşən idmançıların sayının 17 yerlik avtobuslardakı idmançıların sayından 2 nəfər çox olduğu molumdursa, avtobusların sayını tapın.

24 yerlik avtobusların sayı $\mathrm{x}, 17$ yerlik avtobusların sayı y olarsa, $24 \mathrm{x}-17 \mathrm{y}=2$ tənliyini alarıq. Tənliyin tam həllərini tapmaq üçün Evklid alqoritmindən istifadə edək:

$24=17 \cdot 1+2, \quad 17=7 \cdot 2+3, \quad 7=3 \cdot 2+1, \quad 3=1 \cdot 3+0$. 
$\operatorname{~} \operatorname{BOB}(24,17)=1$. Bu alqoritmi tərsinə yazsaq, alarıq:

$1=7-3 \cdot 2=7-(17-7 \cdot 2) \cdot 2=7-17 \cdot 2-7 \cdot 4=7 \cdot 5-17 \cdot 2=(24-17) \cdot 5-17 \cdot 2=24 \cdot 5-7 \cdot 17$

Beləliklə, $24 \cdot 5-7 \cdot 17=1$ bərabərliyini aldıq. Bu bərabərliyi 2-yə vursaq:

24·10-17·14=2 alarıq. Deməli, 24 yerlik avtobusların sayı 5, 17 yerlik avtobusların sayı isə 14 olmalidir.

\section{Notico}

Məqalədə qeyri-müəyyən tənliklərin həllinin araşdırılması nətcəsində müəyyən edilmişdir ki, həllin varlı̆̆ və yeganəliyi aşağıdakı qaydada müəyyən edilə bilər:

Həllin varlığı: 2 məchullu xətti qeyri-müəyyən tənliklərlə həll edilən məsələlərin tam ədədlər çoxluğunda həllinin varlığı üçün tənlikdəki sərbəst həddin məchulların əmsallarının ən böyük ortaq böləninə bölünüb-bölünməməsi şərti yoxlanılmalıdır. Ogər bölünürsə, həll var, bölünmürsə həll yoxdur.

Həlli tapmaq üçün Evklid alqoritmindən istifadə etmək əlverişlidir. Qeyd edək ki, digər üsullar da, məsələn, seçmə, qrafik, vuruqlara ayırma, qalıqlara görə həllin tapılması, zənciri kəsrlər üsulu və s. məlumdur.

Həllin yeganəliyi. Həllin yeganəliyi hər bir məsələnin şərtindən asılı olaraq araşdırılır. Beləliklə, bu tip tənliklərin həllinin araşdırılması məktəb riyaziyyat kursunda verilən praktik məzmunlu məsələlərin həll edilməsi üçün səmərəli vasitədir.

\section{Odəbiyyat}

1. DiophantineEducation.https://mathworld.wolfram.com/DiophantineEquation.html

2. С.А.Степанов. Диофантовые уравнения, ТР. Миан СССР, 1984, том 168, с. 31-45

3. Матиясевич Ю.В. Диофантовые множества. Успехи математических наук, 1972, том 22, вып. 5, с. 185-222 


\section{IÇİNDəKILəR}

\section{HUMANITTAR Və İCTIMAİ ELMLOR BÖLMəSI \\ HUMANITIES AND SOCIAL SCIENCES SECTION}

\section{Qızxanım Nizaməddin qızı Qəhrəmanova}

Analitik psixologiyada uşağın inkişafı problemi 4

Şərəbanı Oli qızı Məmmədova

Nizami Gəncəvinin fikir dünyasında sözün və mütaliənin dəyəri 7

Sədaqət Nəsir quzı Nemətova

İnanclarda mifoloji obrazların yer tutması (Naxçıvan materialları əsasında). 12

Ромелла Али гызы Гюльалиева

Краткий анализ развития законодательства о преступлениях против правосудия 16

Firəngiz Şirin qızı Şirinova

Distant təhsil təhsilin sürətlə inkişaf edən formalarından biri kimi 21

Fəhminə Osgər qızı İsmayılova

Xəbərlik kateqoriyasının linqvistik və sosiolinqvistik aspektləri

Aytən Tahir qızı Kərimli

Türk dilindən keçən sözlərin leksik-semantik funksionallığı

Yusif Qəşəm oğlu Abayev

İqtisadi diverfikasiya iqtisadi rayonların dinamik inkişafın təminatçısıdır 30

Yadulla Xanlar oğlu Oləkbərov

Azərbaycan nağıllarlında sehrli tilsim vasitələri 35

Sahilə Osgər quzı Abbasova

I-IV siniflər üzrə Azərbaycan dilindən folklor materialları etnodidaktik tərbiyə vasitəsi kimi

Yeganə Heybət q1zı Səlimova

Azərbaycan dilçiliyində frazeoqrafiya 44

Jalə İlqar qızı Məmmədova

Vitraj sənətində müxtəlif üslublarda ornamentlərin istifadəsi

\section{Günay Forhad qızı Mustafayeva}

Coğrafiya fənninin tədrisində məlumat mübadiləsi mərhələsində tətbiq

edilən iş üsulları

Məsumə Vasif qızı Məmmədli

Təhsil turizmi və onun Azərbaycan turizm iqtisadiyyatında rolu 57

Nərmin Rasim qızı Namazova

Rusiyada beynəlxalq turizmin inkişaf tendensiyaları

Ayton Zaman qizı Rəsulova

Beynəlxalq turizm inkişafina təsir edən amillər 64

Vüsal İlham oğlu Kərimli

Turizm müəssisələrinin inkişaf etdirilməsində Avropa təcrübəsi 67 


\section{TəBİวT ELMLӘRİ BÖLMӘSİ}

\section{NATURAL SCIENCES SECTION}

Türkanə Mirzəli qızı Đliyeva

Kometlərin tətbiq tarixi 70

Aynur Cümşüd qızı Məmmədzadə

Ziqomisetlərin fermentativ aktivliyi və fizioloji-biokimyəvi xüsusiyyətləri

DəQİQ ELMLəR BÖLMəSİ

EXACT SCIENCES SECTION

Xumar Tofiq qizı Novruzova

Qeyri-müəyyən tənliklər

Kağı formatı: $60 / 84$

$\mathrm{H} / \mathrm{n}$ həcmi: 4,9

Sifariş: 403

“ZӘNGӘZURDA” çap evində çap olunub

Ünvan: Bak1 şəh., Mətbuat prospekti, 529-cu məh.

Tel.: (050) 20959 68; (055) 20959 68; (012) 5106399

e-mail: zengezurda1868@mail.ru 
